\title{
Defended or defunded? Local and state policy outcomes of the 2020 Black Lives Matter protests ${ }^{1}$
}

\author{
${ }^{2}$ Mathis Ebbinghaus, Nuffield College, University of Oxford \\ Nathan Bailey, St. Hilda's College, University of Oxford
}

Jacob Rubel, Tufts University

November 19, 2021

Copyright: Copyright 2021. Mathis Ebbinghaus. All rights reserved. This paper is for the reader's personal use only.

Keywords: social movements; protest; Black Lives Matter; policymaking; local politics

This article provides novel evidence on the local policy outcomes of the largest protest movement in U.S. history: the 2020 Black Lives Matter protests. Building on a hand-compiled dataset containing information on the 300 largest cities in the United States, data on state legislation, and comprehensive protest data, we assess whether two core political demands of the movement were realized. We find that protest did not affect city police budgets but did lead to the adoptions of state police reform. We do not find compelling evidence that protest affected agenda setting at the state-level. Although inconsequential in local politics overall, protest proved counterproductive in cities with large white population shares and large Republican population shares. We argue that local and state politics offer different political opportunities for protests to succeed. In state politics, protest creates electoral incentives to make political concessions. In local politics, a lack of political threat and the perception of protest as inconvenient create political incentives to resist policy change.

\footnotetext{
1 Michael Biggs and Dan Snow provided valuable guidance, comments and suggestions throughout the project. We also thank Liliana Andriano, Effrosyni Charitopoulou, Kasimir Dederichs, Horst Ebbinghaus, Stephen Fisher, Victoria Gierok, Peter Levine, Emma Matteo, Scarlett Yee-man Ng, David Rubel, and Huiru Wang for useful feedback on earlier drafts of this paper. Samuel Drezner, Jane Romp, and Nicole Setow aided with collecting the budget data and provided valuable comments in a workshop on the outcomes of social movements.
}

${ }^{2}$ Correspondence to Mathis Ebbinghaus, Email: mathis.ebbinghaus@nuffield.ox.ac.uk 


\section{Introduction}

Protest is local. Some streets, squares or parks turn into sceneries of protest when protesters are making claims to political authority. But does protest matter for politics in the locality where it erupts? We address this question by investigating whether protest matters for local and state policymaking. In contrast to protest, politics are no longer local. The American promise of federalism to engage citizens in local politics is no longer kept (Einstein and Kogan 2016; Hopkins 2018; Schaffner, Rhodes, and La Raja 2020). Voter turnout in local elections and civic engagement have declined since the 1960s (E. Oliver and Ha 2007; E. Oliver, Ha, and Callen 2012; Putnam 1995; Galston and Levine 1998; Hajnal and Lewis; 2003). What is left of local politics is largely influenced by national political dynamics. Political polarization and party ideology affect all levels of political decision making (Tausanovitch and Warshaw 2014; Benedictis-Kessner and Warshaw 2016; Benedictis-Kessner and Warshaw 2020). In the context of increasingly nationalized local politics (Hopkins 2018), the role of local protest warrants systematic investigation.

Whether protest can persuade policymakers has been fiercely debated. Recent scholarship suggests it does, and carefully delineates the mechanisms through which protest can affect policy. Protest has proven particularly successful at influencing political agendas (Andrews and Caren 2010; B. King, Bentele, and Soule 2007; Baumgartner and Mahoney 2005; Baumgartner and Jones 1993; Earl et al. 2004; Smith et al. 2001; Olzak and Soule 2009; Vliegenthart et al. 2016; Walgrave, Soroka, and Nuytemans 2008; Walgrave and Vliegenthart 2012). When protest affects political outcomes, its effects are often moderated by organizational features of social movements (Gamson 1975; McCarthy and Zald 2002), or the political environment in which they take place (Meyer and Minkoff 2004; Soule and Olzak 2004; Meyer 2004; McVeigh, Welch, and Bjaranason 2003; McVeigh, Neblett, and Shafiq 2006). 
Existing scholarship examines how protest shapes political outcomes at the federal or state-level but neglects when protest targets local politics. This is an important omission as protest can bear on the interests of national, state, and local governments alike (Tilly 2008). To analyze the effects of protest on federal policymaking, scholars commonly use variation in protest over time instead of spatial variation. It therefore remains an open question whether protest affects policymaking in the localities where they take place, either at city or statelevel. Methodologically, our analysis is inspired by Biggs and Andrews (2015) on sit-ins in the American South which uses city-level analysis to assess the effect of protest on the decisions of businesses and local elites to desegregate.

Our article investigates the largest protest wave in U.S. history, which followed the murder of George Floyd on 25 May 2020. We focus on protesters' main demands to defund and reform the police by investigating whether protests led to the reduction of municipal police budgets. In the remainder of this article, we follow the common meaning of the term defunding which refers to reductions in police budgets, rather than entire budget cuts. We also investigate the effects of protest on state bills regarding law enforcement to contrast similar types of policy at different levels of political decision making.

We advance a theoretical argument for how two core concepts in the scholarship on social movements - threat and persuasion - can help to explain how protest affects different levels of political decision making. Protest may be particularly persuasive in local politics, where exposure to protest is more direct than in state politics. However, the ability to persuade audiences hinges on successful interaction between protesters and policymakers. Black protesters may face prejudices that hinder successful interaction. We theorize that an even greater challenge to persuasion is political threat. Protest poses a greater electoral threat to state policymaking than to local policymaking. In local politics voter turnout is low, interest groups have substantial bargaining 
power, and the electorate and protesters share few demographic characteristics. Policymakers therefore remain unthreatened by protest. We further argue that failure to respond to the inconvenience caused by protest 'immediate threat' - can both turn into electoral threat and lead to emotional responses which make concessions unlikely. Immediate threat is greater at the city-level where policymakers are directly exposed to protest. Our analysis brings to light whether protest is more successful at higher or lower levels of political decision making.

Research on local politics is often impeded by a lack of available data (Trounstine 2009). We address the problem of data availability by collecting original data on the city and police budgets of the 300 largest cities in the United States. This allows us to identify relationships between changes in police budgets and protest. Our protest variables derive from Crowd Counting Consortium (2021) data, a commonly used source for studying the Black Lives Matter protests (Pressman and Choi-Fitzpatrick 2020; Andrews, Caren, and Browne 2018; Timoneda and Wibbels 2021). We take advantage of the timing of city councils' budget hearings that often happened in the months following protests.

We find that the Black Lives Matter (BLM) protests did not lead to the defunding of city police budgets. If anything, protest may have led to increases in police spending. Whereas protesters were unsuccessful at realizing one of the core political demands of the movement at the local-level, protesters pushed state legislators to approve new police reform at the state-level. However, we also find that protest cannot explain the number of proposals of state legislation on police reform. This finding suggests that protest may have been successful at the adoption, but not the agenda setting stage of the policymaking process. Although we cannot be too confident that protest led to increases in police budgets across the whole sample of cities, those with large 
white population shares and large Republican vote shares were more likely to increase their police budgets. In cities with these characteristics, we find evidence that protest proved counterproductive.

Our results have broad implications for scholarship on social movements. We shed light on a crucial moment in the history of black resistance to oppression by providing systematic evidence on the policy outcomes of the Black Lives Matter movement. The different effects of protest at state and local levels demonstrate the importance of differentiating both theoretically and empirically between different political levels at which protest targets policymaking.

\section{Theory: Integrating the Local}

Local politics has received a revival in mainstream political science (Trounstine 2009; Warshaw 2019). Local governments increasingly operate along partisan and ideological lines that resemble cleavages at the national level. This new emerging paradigm of an 'increasingly United States' (Hopkins 2018) has replaced the traditional view that city politics are fundamentally different from national politics (Peterson 1981; Anzia 2021). Local media is replaced by national media, participation in local elections is in decline, and marginalized social groups are alienated from local politics (Martin and McCrain 2019; Schaffner et al. 2020). These insights into American federalism raise the question of whether local and state policymakers respond to the political demands of their citizens.

Protest is one important way of making political demands. Whether protest affects local and state policymaking in the context of nationalized politics is an important gap in our understanding of contemporary American federalism. As one social movement often only addresses either state or federal level policies, the effects of protest on different levels of political decision making have not 
been studied together, which has impeded comparative studies of protest outcomes. Moreover, we know generally little on the effects of protest on local policy. This blind spot in extant knowledge on the political outcomes of protest is understandable. Given the scarcity of data on local politics, previous scholarship on the policy outcomes of protest has instead turned to either state or federal policies.

The consensus is that protest can affect policy at state or national levels in the agenda setting stage but does not usually lead to the adoption of new legislation. Although protest often failed to achieve new legislation directly, protest affected the attention to rights issues in congress (B. King, Bentele, and Soule 2007), influenced how often topics are raised in parliamentary debates (Vliegenthart et al. 2016), shaped political parties' agendas (Hutter and Vliegenthart 2016), and even affected the political beliefs of party officials (Wouters and Walgrave 2017).

At later stages in the legislative process protest has proven less successful (Olzak and Soule 2009). For example, women's suffrage movements have brought women's suffrage to the legislative forum but had little effect on voting behavior to pass new legislation (B. King, Cornwall, and Dahlin 2005) and environmental protest led to more congressional hearings on the environment but did not exert a direct effect on policy (Johnson 2008).

A foundational premise in scholarship on protest is that protest matters through numbers (Della Porta and Diani 2006; DeNardo 1985). Numbers figure prominently in Tilly's well-known model for how movements succeed, which is encapsulated in the acronym WUNC: Worthiness, Unity, Numbers and Commitment. The most explicit theorization of how numbers matter for policymakers is a signaling model of mass political action. The model assumes that the number of protest participants is viewed by politicians, often through 
media channels, as a signal for what the public desires (Lohmann 1993; Wasow 2020). Politicians are interested in reelection and therefore are best served by following the majority's expectations which finds expression in large-scale activism. The more people participate, the stronger the signal. Others have argued that large numbers of participants can influence policymakers through influencing protest audiences (Madestam et al. 2013), rather than taking protest itself as the direct expression of public interest (Gillion 2020; Soule and Olzak 2004).

Previous research on the effects of protest on state outcomes guides our expectations on the effects of BLM protests on state police reform, but we are entering new empirical and theoretical territory when focusing on local policy. Andrews (2001) investigates the local effects of the Mississippi Civil Rights Movement between 1965 and 1971, but his focus is on movement infrastructure that proved successful at gaining access to decision making bodies and the content of poverty programs. Instead, our focus is on the effect of the number of protesters itself. The following theoretical exploration is based on the core assumption that numbers matter for the success of protest because many people can either persuade or coerce policymakers into concessions. We leave unaddressed other avenues for movements to affect policy. Crucially, our analysis does not assess how the organizational strength of a movement can lead to protest outcomes. Instead, we suggest two pathways through which protest participants can threaten or persuade policymakers in local and state politics, respectively.

\subsection{Persuasion}

The power of protest can lie in its ability to persuade. Protest is more directly perceived when it erupts in proximity to audiences. For example, white Southerners were more likely to develop favorable attitudes towards the Civil Rights movement if they lived near centers of movement activity and if they 
lived close to protest audiences who held positive views towards blacks (Andrews, Beyerlein, and Farnum 2016). By extension, proximity between protesters and policymakers could have led to changes in policymakers' response to protest, both directly and indirectly through changes in public opinion. The larger the number of protest participants the greater the chances of both direct and indirect exposureto protest.

Local politics can be thought of as a domain of direct interaction between political actors and citizens. Hence the dictum: All politics is local. This is the idea of federalism, admired and praised by Tocqueville according to whom "town meetings are to liberty what primary schools are to science; they bring it within the people's reach, they teach men how to use and how to enjoy it. (W)ithout the spirit of municipal institutions it cannot have the spirit of liberty (1835: 57)." Applying this argument to protest suggests that protest at the local level leads to direct interaction between policymakers and protesters. Indeed, the local BLM protests often included protests in townhalls, and meetings between politicians and activists.

Successful interaction between policymakers and protesters is a prerequisite for persuasion. Despite geographical proximity, local politics can be far removed from people who lack the cultural, economic and social means to enter the political arena and to be taken seriously by decision makers. Black individuals who fight against structural disadvantages, may face prejudices, which can hinder interaction that persuades and brings about political change (Schaffner et al. 2020).

\subsection{Political Threat}

Political threat is the other challenge to persuasion. The idea is that large numbers of participants can impose costs on movement targets (Tilly 2006; Luders 2006; Biggs and Andrews 2015). Indeed, classic sociological 
explanations have seen the main pillar of mass protest in protesters' ability to threaten political elites (Piven and Cloward 1979). The connotation of threat is different from everyday parlance. Threat here means political threat. Big and disruptive movements disrupt the everyday processes of politics thereby undermining existing political arrangements. Political concessions depend on policymakers' calculations on whether protest poses a threat to their political power. In Democratic states, public support of protest affects politicians' perceived chances of reelection.

We apply this argument to local and state politics. At the state-level, electoral turnout tends to be higher than in local elections where participation is notoriously low (Who Votes for Mayor 2016). Voters in local elections are also older than the average voter in state elections. BLM protesters were young and thus bore little resemblance to the electorate in local elections, which constrained protesters' bargaining power in local politics. Protesters' own alienation from local politics may not matter if protestors attract audiences, who affect policymakers' chances of re-election. Opinion polls reveal, however, that in June 2020 only 23 percent of Americans were in favor of decreasing municipal police budgets, a number that dropped to 15 percent in September 2021. Even among blacks, defunding never found majority support (Parker and Hurst 2021).

Protesters' demographics and limited public support for defunding city police budgets rendered protest largely unthreatening to local policymakers. What is more, their political demands directly challenged the interests of societal subgroups that mattered to policymakers. When national level developments like the economy or the presidential election are not replacing local politics, it is local interests of wealthier groups or union members to which local politicians are accountable, assuming that they are motivated by reelection (Anzia 2021; Jurjevich et al. 2016; Hopkins 2018; Schaffner et al. 2020). Police unions can rely on their collective bargaining power (Dharmapala, McAdams, and 
Rappaport 2020). For example, commentators have highlighted the role of police unions in affecting local policymaking through donations and lobbying (Scheiber, Stockman, and D. Goodman 2020). Many city council members received campaign donations from police unions, and subsequently opposed efforts to defund the police, lending credence to police unions' political influence.

\subsection{Immediate Threat}

Apart from the classic view that protest can pose a political threat, protest can also be threatening in a much more prosaic sense: it can create annoyance and inconvenience. For convenience, we shall call this dimension of threat 'immediate threat'. The smaller the political unit of representation, the greater the relative inconvenience caused by protest and the greater the inclination of policymakers to prepare for future unrest. In Los Angeles, for example, city council president Nury Martinez called Black Lives Matter protesters "completely out of control" after they had demonstrated in front of her home. She expressed her concern that "This is about protecting our family members, our children, and our neighbors from aggressive, targeted protests at all hours of the day and night", "When you come onto my street to yell on bullhorns outside of my home, you're not only disrespecting my family, but you're also disrespecting the community and neighbors who live there" (D. Smith and Winton 2021). In democratic societies annoyance does not qualify for direct repression, and police budget decisions do not deter current unrest. However, we argue that immediate threat has an affective and an instrumental dimension that matter for policymakers' responses to protest.

First, policymakers may feel morally responsible for responding to inconvenient social unrest. The duty to protect their local community is part of policymakers' identity both as politicians and as citizens. Because political representatives are personally affected by protest, concessions can be viewed 
as a lack of recognition for the trouble that protest may cause in policymakers' local community. This type of response may not be driven by political motives directly. Second, failure to respond, if only this means preparing for the inconvenience caused by protest, can turn into a political problem for local policymakers. This is the crucial link between immediate and political threat. The defunding of municipal police budgets could publicly be perceived as undermining the ability to respond to future inconvenient protest. Immediate threat of protest can thus revert to political threat. At the state-level, however, where the units of political representation are larger, and policymakers are only indirectly exposed to protest, immediate threat is less important. In light of these theoretical considerations, we are open to the possibility that police budgets may increase because of local protest, whereas police reform may be an outcome of BLM activism at the state-level.

\subsection{Theorizing Heterogenous Effects}

Our main theoretical argument is about the effects of protest at city-level and state-level, respectively. The argument leads to the expectation that protest achieves its goals at the state-level but may be unsuccessful at the local level. Failure to achieve a movement's goals overall, does not preclude the possibility that protest might matter under certain conditions even at the local level. We consider how protest matters given different city characteristics that correspond with the main dividing lines in American politics: Do we expect protest to lead to defunding of city police budgets in places that were poor, black, and Democratic?

In 'Poor People's Movement', Piven and Cloward (1979) famously argued that the only means through which poor people can achieve political success is disruption; the power of the street, rather than organization and realpolitik. The argument has received widespread criticism for neglecting the role of movement organizations in advancing political agendas. However, it may also 
fail to appreciate the nature of political threat. Recent scholarship has revealed a blatant gap in political representation between poorer and wealthier individuals (Schaffner et al. 2020). Under the assumption that policymakers care for re-election, concessions to poor people may be politically futile. Combined with our general argument that direct exposure to inconvenient protest can hinder political concessions, and that persuasion is the result of direct interaction between people who have access to political decision making, then protest would not matter in poorer cities. It is true that the power of the street may be poor people's most powerful weapon, but it's a weapon that can be turned against its owner: numbers can be threatening, but without the political threat, indifference or even repression may be the dire consequence of poor people's efforts to influence policy.

Class and income differences are one line of division in American politics, racial disparities are another. Black people have a smaller chance of being in contact with government officials and vote less, both factors that limit their political leverage. On the other hand, black people viewed demands to defund the police budget more favorably than whites who were largely opposed to reductions in police budgets and might therefore have caused a greater political threat (Parker and Hurst 2021). We therefore conjecture that in cities with large black population shares protest could be more likely to make concessions to Black Lives Matter protests, whereas in cities with larger white population shares, protest might have been counterproductive.

Political polarization has become a defining characteristic of American politics. Social justice protests could be more successful in places where audiences are sympathetic with the movement's cause, welcoming concessions to protesters. Policymakers may evaluate the costs and benefits of concessions depending on the Democratic vote share. When protesters do not recruit from the electorate, and when audiences do not sympathize with protesters, we hypothesize protesters' political threat to be smaller. Democrats were generally more 
sympathetic towards the BLM movement. Protest could therefore be more successful in Democratic cities than in Republican cities, where we expect protest to be counterproductive.

\section{Case Selection: Black Lives Matter Protests}

In 2014, Black Lives Matter emerged as the slogan of a protest wave that erupted in response to the acquittal of a white civilian who killed a black teenager. Building on a history of black resistance to repression (P. Oliver 2020) Black Lives Matter has grown into a movement that carried the fight against racial inequalities across the United States. It has evolved into a decentralized activist network. Its primary objective is to "eradicate white supremacy and build local power to intervene in violence inflicted on Black communities by the state and vigilantes" (Black Lives Matter 2020). Spurred by the Twitter hashtag \#BlackLivesMatter, hundreds of thousands had already joined the movement since 2014, but after the murder of George Floyd on 25 May 2020 the movement quickly developed into one of the largest protest waves in the history of the United States. Between May and July 2020, an estimated total of 16 to 25 million people took to the street in their fight against racial injustices (Buchanan, Bui, and Patel 2020). Black Lives Matter has become a nationwide protest movement. Grassroots protest rather than centralized organization is a defining characteristic. Therefore, the Black Lives Matter movement lends itself to the systematic study of the effects of protest on policy, rather than movement activity more generally (Andrews 2001). Figures 1 and 2 indicate that BLM protests were far-reaching, affecting many cities and states, resulting in extraordinarily large protests in a subset of those. With as many as 12,391 protesters per month per 100,000 inhabitants, Portland, Oregon, is the city with most protest in our dataset, followed by Providence, Rhode Island, and Salt Lake City, Utah. 

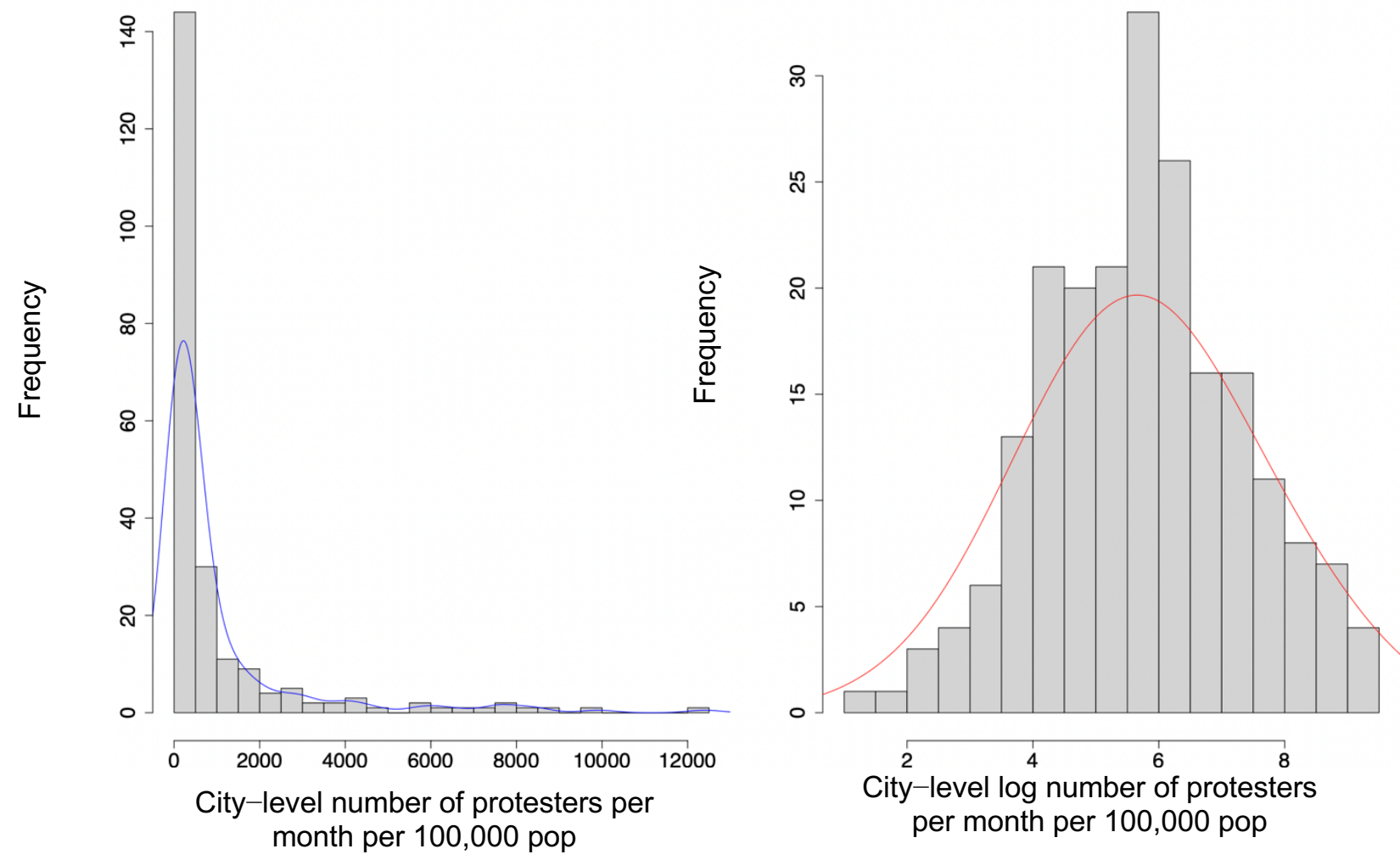

Figure 1: Distribution of number of recorded BLM protesters across cities
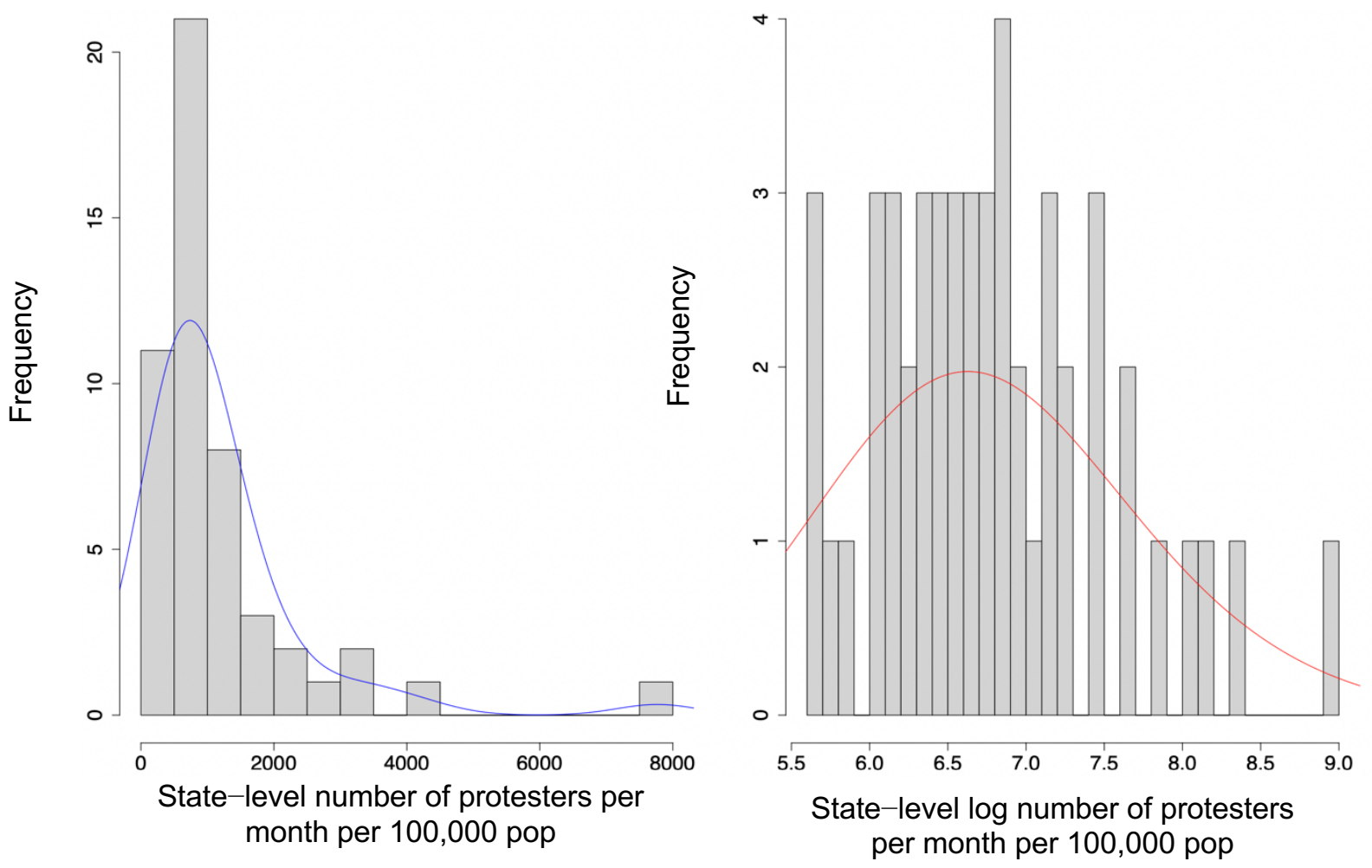

Figure 2: Distribution of number of recorded BLM protesters across states 
BLM is characterized by group leadership. Instead of a charismatic leadership model often associated with the Civil Rights Movement, BLM has embraced a decentralized structure where power and authority are divided across local units rather than bundled in a single national organization. Within the United States, protest erupted in many places, often at the same time and without centrally coordinated efforts by movement organizers. This enormous geographical dispersion in grassroots participation offers an opportunity to study whether local protest affects policymaking in the places where protest happens.

Local and nationally dispersed protest was partly a consequence of the Covid19 pandemic which disenabled travelling to attend mass protests in major cities. Washington hosted Black Lives Matter protests but in contrast to the 2017 Women's March or the 1968 March on Washington, Covid-19 disincentivized people from other parts of the country to join protest events in the capital. Black Lives Matter was an unusually local protest movement.

One of the main targets of the movement, the police, are politically accountable to and financed by local city councils, providing a direct link between local protest and local politics. State legislation also addresses protesters' demands on policing that were expressed in some states more often and more forcefully than in others. Examples of legislation categories include: investigation and discipline, oversight, policing alternatives and collaboration as well as use of force. State and local policies offer different institutional avenues for political action which impedes direct comparability, but police related legislation can be found at both the city and state-level.

Alongside broader topics about historical injustices and racial discrimination, police reform, and the financial restructuring of city police departments advanced to the main tangible demands of the Black Lives Matter movement. 
The slogan brings to light the dissatisfaction of many Americans with the police. The police are blamed for failing to protect black communities from crime, for disproportionately policing black individuals, and for fulfilling too many services that are deemed outside the purview of police action. It is beyond the scope of this article to elaborate on each of these propositions at length (but see Ransby 2018; Lebron 2017; Vitale 2017). Defunding the police appears to represent a revival of the abolitionist tradition (Du Bois and Mack 2012). Angela Davis claims that Du Bois "pointed out that in order to fully abolish the oppressive conditions produced by slavery, new democratic institutions would have to be created" (Davis 2005: 73). Whether or not this interpretation is correct, the demand to 'defund the police' has its roots in radical black activism. It may help to explain why the demand has received widespread attention despite mixed public support (Rakich 2020).

The demand to defund the police has captured the attention of American Twitter users after the murder of George Floyd on May 25, 2020. Our analysis of Twitter data reveals the relative prominence of the demand. ${ }^{1}$ Figure 3 displays word frequency counts for a sample of 10,000 Tweets mentioning '\#BLM' from US-based users throughout 2020 (with common stop-words removed). Many words used in these tweets relate to aspects of the movement, such as 'black', 'white', and 'racism'. The three highlighted terms - reform, defund, and statue - directly relate to core demands of the movement. We observe the strongest associations between BLM and police reform and defunding police budgets. Fewer tweets related to BLM mentioned 'statues', which likely pertained to the symbolic demand to remove statues that honor people involved in slave trade and other forms of black oppression. We argue that focusing our analysis on the two issues of defunding and police reform is justified because of their prominent association with the BLM movement as

\footnotetext{
${ }^{1}$ We also analyzed Google trend data by illustrating the daily frequency of Google web searches for a range of keywords related to the BLM movement. "Defunding" reached the highest peak value in early June and recorded the greatest mean level of interest throughout the period. (See Appendix J).
} 
indicated by trends in both Twitter and Google data.

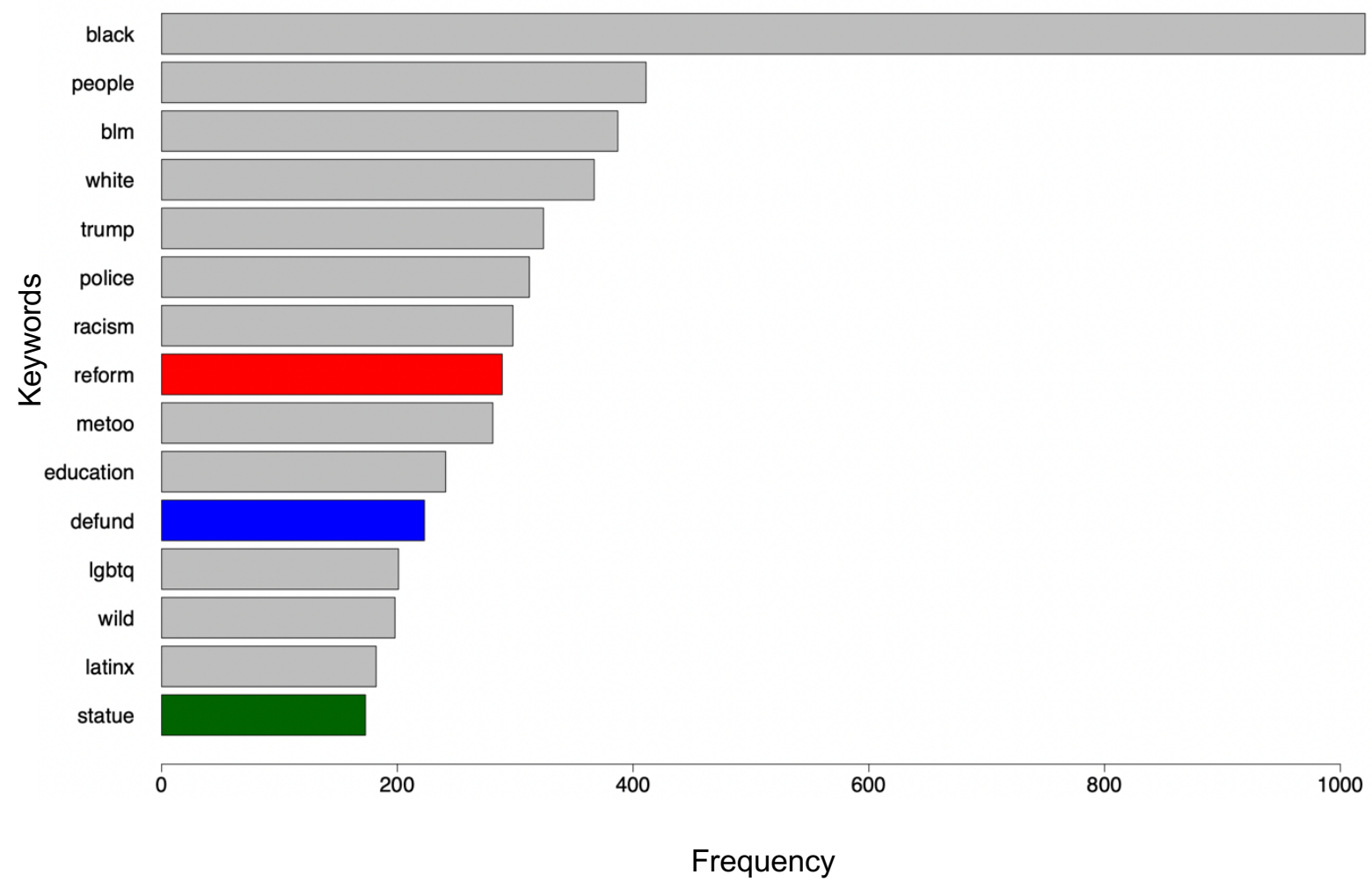

Figure 3: Word frequency for sample of Tweets mentioning \#BLM' in 2020 on local and state policymaking

There is a further analytical advantage to concentrating on the policy demands of defunding and police reform. The policymaking process which determines whether to defund the police is highly localized - as we will discuss, most decisions about funding for police services are taken within cities. Decisions about training programs, investigatory processes, means of holding police officers accountable, and mandates for on-duty body cameras - all decisions about police reform - are taken within different state legislatures. Investigating whether protest succeeded in pushing for defunding in city police budgets and promoting police reform in state legislatures offers a welcome opportunity to study the different effects of protest on state and local policymaking. 


\subsection{Police Budgeting Process}

Each year, city governments debate and approve municipal city budgets. State and city spendings combined are of similar volume to federal spending and thus influence a substantial portion of government activity in the United States (US Bureau of the Census 2021; Congressional Budget Office 2020). City governments have jurisdiction over education spending, infrastructure, sanitation, parks, and crucially, police spending.

All U.S. cities follow a similar budgetary process. City agencies submit budget requests to the mayor which are subsequently reviewed by the mayor and the office of finance. Based on these requests, the mayor's office releases the city's budget proposal which articulates funding priorities. Following the budget proposal, the budget moves to the city's legislative body for review. City councils debate spending, often in consultation with the general public, before they approve a final budget that is subject to an additional approval by the mayor.

The role of public engagement in the budget approval process is the crucial juncture for political activism. During the budget review process, city councils engage in various forms of public outreach such as surveys and public budget hearings in which citizens are invited to express their concerns, support, or recommendations for changes. As Black Lives Matter protests coincided in many cities with the budget review process, activists sought to influence city councils' deliberation before the final budgets were approved. Scenes of local activists passionately confronting their local representatives are powerful imagery of city council halls transforming into places of contentious politics. To take just one example, on June 5, 2020, the Dallas City Council had 213 public speakers airing their grievances for over 5 hours: "These speakers were in pain. Some cried. [...] their voices shook through their allotted minute and a half" (M. Goodman 2020). The subsequent city council meeting lasted 9 hours 
and developed into shouting between the mayor and council members. Exchanges between city council members and activists may have been effective.

Figure 4 shows that in some cities, the share of the city budget dedicated to policing did not change between 2019/20 and 2020/21. However, in many cities, the share of the police budget either decreased or increased. In relative terms, 122 cities defunded, whereas 132 cities increased the share of city spending devoted to policing. In absolute terms, the sum of police budgets in our sample reduced by $2.05 \%$ from $2019 / 20$ to $2020 / 21$, from $\$ 37.14$ billion to $\$ 36.38$ billion. Yet, citywide budgets shrank generally across the same period. Police budgets as a share of total spending remained stable, falling from $10.47 \%$ of city spending in $2019 / 20$ to $10.19 \%$ in $2020 / 21$. We shall now turn to an empirical example. It will make the case for a possible relationship between protest and defunding more compelling.

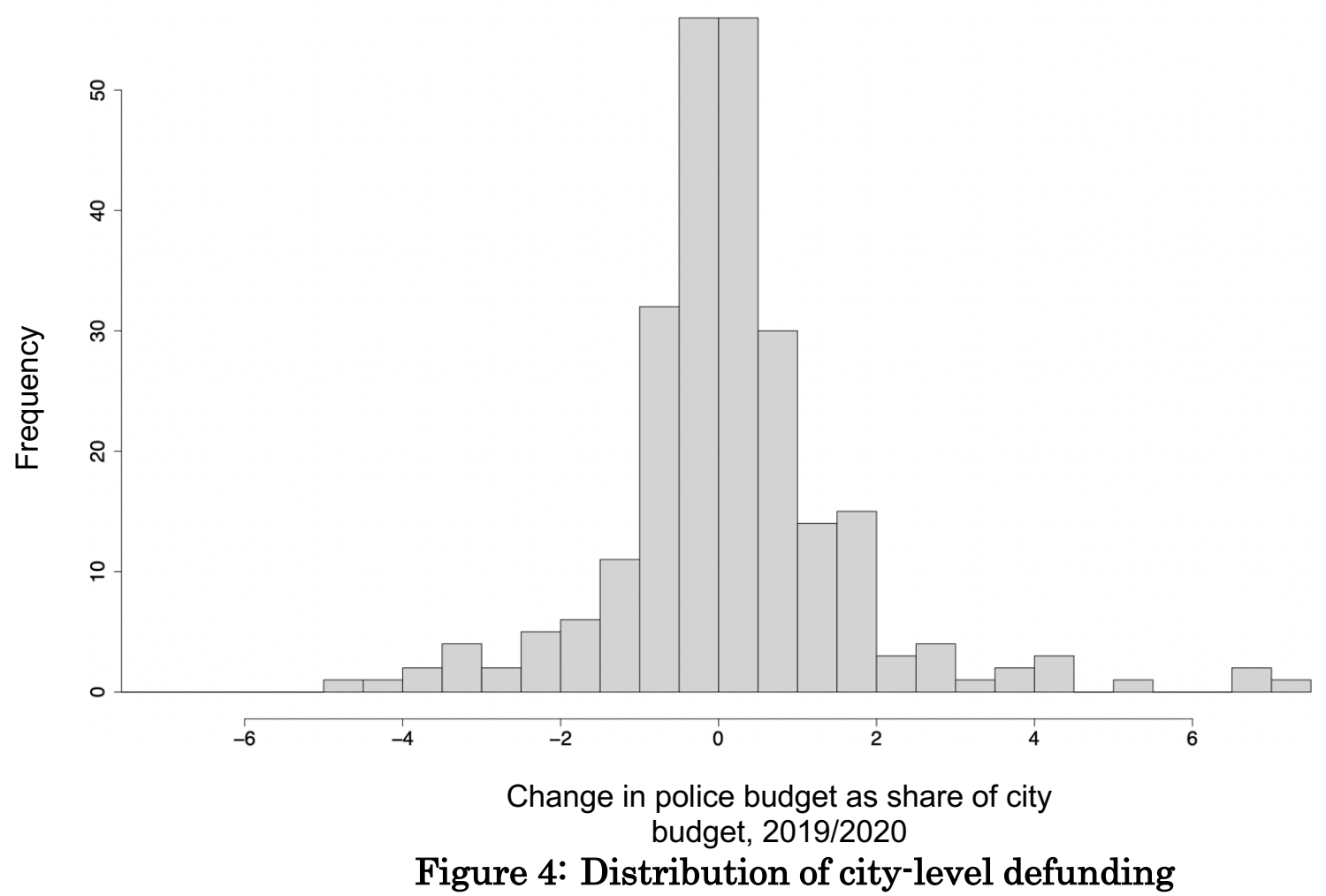




\subsection{Protest and Defunding}

On May 25, 2020, Minneapolis gained notoriety in 9 minutes and 29 seconds. The killing of George Floyd by a white police officer became a powerful symbol for police violence against black people. What Randall Collins (2004: 102-140) might call "emotional energy" translated into large Black Lives Matter protests in the city of Minneapolis. In the midst of such emotional effervescence, the demand to defund the police resonated with many who saw the murder of George Floyd as emblematic for problems with racism and racist police.

Protesters' demands to defund city police budgets did not go unnoticed. Only thirteen days after former Minneapolis police officer Derek Chauvin killed George Floyd, nine city council members stood on a stage with block letters at their feet: "Defund the Police" (Herndon 2020). Following the first wave of protest, a majority of Minneapolis City Council members voted in favor of defunding their police department. The council's draft charter amendment called for replacing the Minneapolis Police Department with a Department of Community Safety and Violence Prevention. A "division of law enforcement services" was no longer required. The proposal was halted by the city's charter commission and did not go before voters in November 2020.

In November 2020, after thousands of people had protested for more than 6 months in the streets of Minneapolis (see Appendix K), the Minneapolis city council voted in favor of defunding their police department by the remarkable sum of $\$ 28,709,000$. What went largely unnoticed is that the total city budget also decreased dramatically. The share of the police budget as part of the total budget dropped by 1 percentage point, from $12.3 \%$ to $11.3 \%$. City council members seem to have responded to protesters' demands.

In other cities with mass protest city council members substantively reduced their police budgets. In Louisville, Kentucky, another city like Minneapolis 
where protesters demanded to defund the police, the police budget was reduced by $\$ 750,200$. In absolute terms, this is a much smaller amount than in Minneapolis. However, as the city budget increased at the same time, the police budget was reduced by as much as $3.6 \%$. This highlights the importance of measuring police budgets as the percentage share change of the total or general city budget.

Table 1 shows that a few cities with high-profile protest experienced defunding of their budgets, whereas other cities chose to increase police budgets. Selected case studies do not help to decide whether activists were right in assuming that "decision makers have seen what it's like in the streets" (M. King 2021). To decide whether protest mattered at the city-level rigorous statistical analysis is necessary. But these cases do show that city officials were able to respond to protest in their budget decisions.

\begin{tabular}{|c|c|c|c|c|c|}
\hline City name & Protesters per-month per 100,000 pop. & Total protesters & Change in police budget, 19/20-20/21 (USD) & Change in city budget, 19/20-20/21 (USD) & Change in police budget share of city budget \\
\hline Portland, OR & $12,391.850$ & 96,972 & $-8,663,584$ & $-313,290,450$ & 0.071 \\
\hline Providence, RI & $9,910.874$ & 27,052 & $5,999,473$ & $-259,251,734$ & 6.817 \\
\hline Salt Lake City, UT & $8,503.110$ & 16,790 & $-3,277,509$ & $-669,060,009$ & 1.961 \\
\hline Cambridge, MA & $8,290.050$ & 7,850 & $2,541,215$ & $36,879,990$ & -0.126 \\
\hline Eugene, $\mathrm{OR}$ & $7,746.743$ & 13,221 & $5,601,148$ & $31,630,935$ & 0.381 \\
\hline Washington, DC & $7,603.156$ & 168,376 & $-9,590,317$ & $1,475,490,000$ & -0.382 \\
\hline Sterling Heights, MI & $7,468.944$ & 7,000 & $2,111,270$ & $-48,342,650$ & 4.021 \\
\hline Hartford, CT & $6,654.491$ & 10,163 & $-2,964,709$ & $-23,913,081$ & -0.186 \\
\hline Nashville, TN & $6,193.924$ & 31,798 & $5,728,900$ & $134,644,200$ & -0.275 \\
\hline Oakland, CA & $5,903.593$ & 26,199 & $11,411,099$ & $-4,170,551$ & 0.739 \\
\hline
\end{tabular}

Table 1: Top ten cities by protest per month per capita and change in police and city budgets

\subsection{Demand for Police Reform}

Demands for police reform are addressed in state legislation. We focus on police reform bills at the state-level where we take advantage of spatial variation in protest. We identify four categories that closely match protesters' demands: First, 'investigation and discipline' encompasses legislation that regulates "departmental and independent investigations into critical incidents, mandated disciplinary action and procedures, including Law Enforcement Officer Bill Rights" and provisions restricting or providing access to disciplinary action (National Conference of State Legislatures 2021). Second, 
'oversight' consists of legislation on law enforcement oversight bodies with "civilian oversight boards that review or recommend law enforcement policy and time-limited task forces or study committees" (National Conference of State Legislatures 2021). Third, 'policing alternatives and collaboration' are bills "authorizing and funding alternative responses for law enforcement, including collaborations with behavioral health, medical and social services professionals" (National Conference of State Legislatures 2021). Fourth, 'use of force' "includes legislation regulating use of force, including deadly use of force, excessive force, less lethal force, duty to intervene, duty to report, legal duties, and liabilities including changes to qualified immunity, and regulation of specific types of force such as chokeholds or tear gas" (National Conference of State Legislatures 2021).

For each of the four categories of state legislation, we have data on the total number of relevant bills proposed, as well as the number of proposals that are eventually accepted. We can thus differentiate between the agenda setting and adoption stage of the policy process. Prior studies have tended to focus on either stage in the policy process and found effects of protest at the agenda setting, but not the adoption stage (Andrews and Caren 2010; B. King, Bentele, and Soule 2007; Baumgartner and Mahoney 2005; Baumgartner and Jones 1993; Earl et al. 2004; J. Smith et al. 2001; Olzak and Soule 2009; Vliegenthart et al. 2016; Walgrave, Soroka, and Nuytemans 2008; Walgrave and Vliegenthart 2012).

\subsection{Protest and Police Reform in Oregon and Beyond}

The Black Lives Matter protests occurred across the state of Oregon as it did across many states in the United States. For Oregon alone, our dataset counts a total of 4,161 protesters per month per 100,000 urban population distributed across an average of 9 protest events per month. Figure 5 substantiates that protests were followed by police reform proposals and adoptions. In 2020 alone, 
following May 2020, 16 police reform bills were proposed and 5 accepted. In substance, bills often directly related to problems that ensued during protests in Portland, such as requiring officers to wear visible identification on their uniform, or to curb law enforcement's use of gas and impact munitions (Wong 2021).

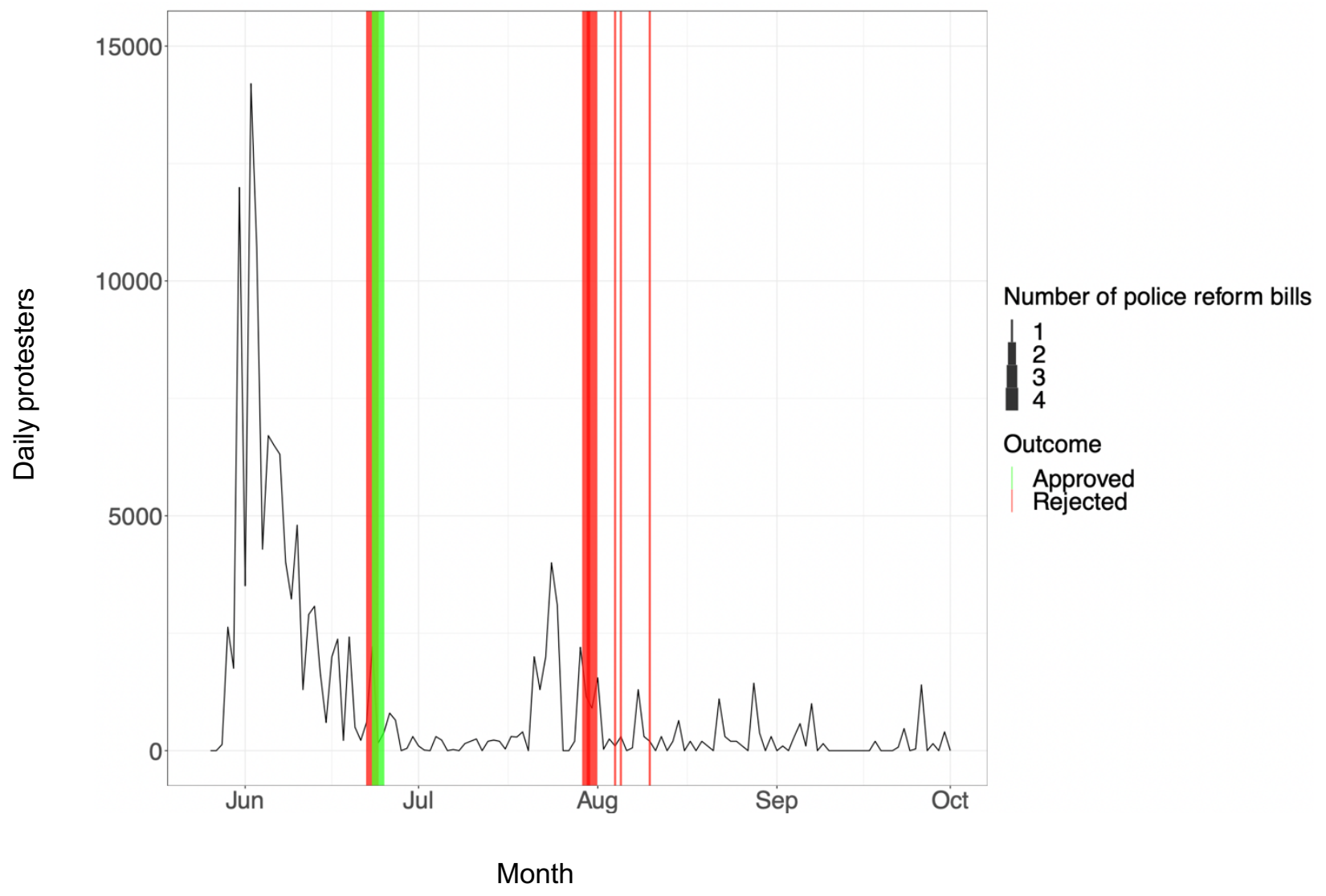

Figure 5: Protest and approved police reform bills in Oregon

Our analysis reveals whether the link between protest and state police reform holds when controlling for relevant variables and proves generalizable beyond the illustrative example of Oregon. Figures 6 and 7 show the distribution of police reform bill approvals and protest per head of urban population across states. 


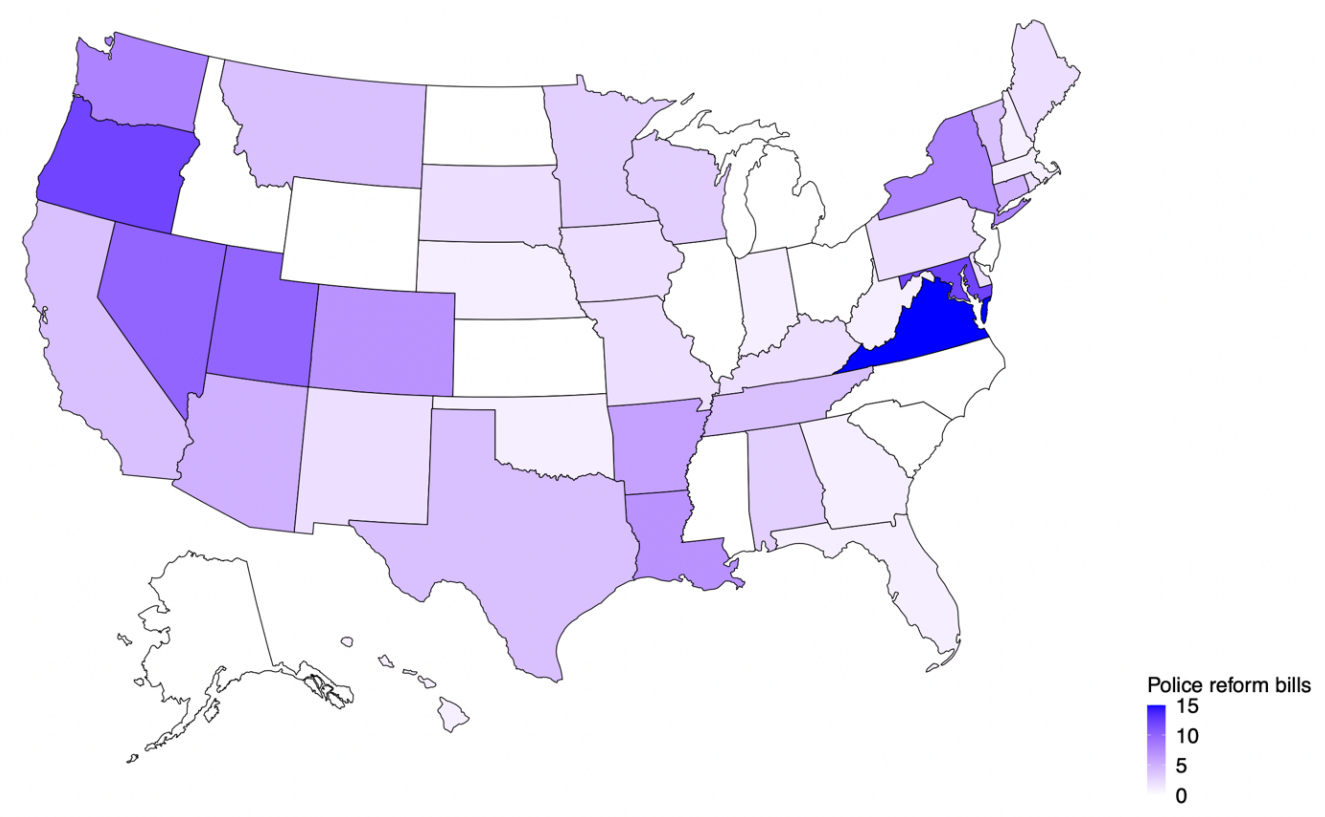

Figure 6: Police reform bills approved in U.S. state legislatures, 2020/21 by U.S.state

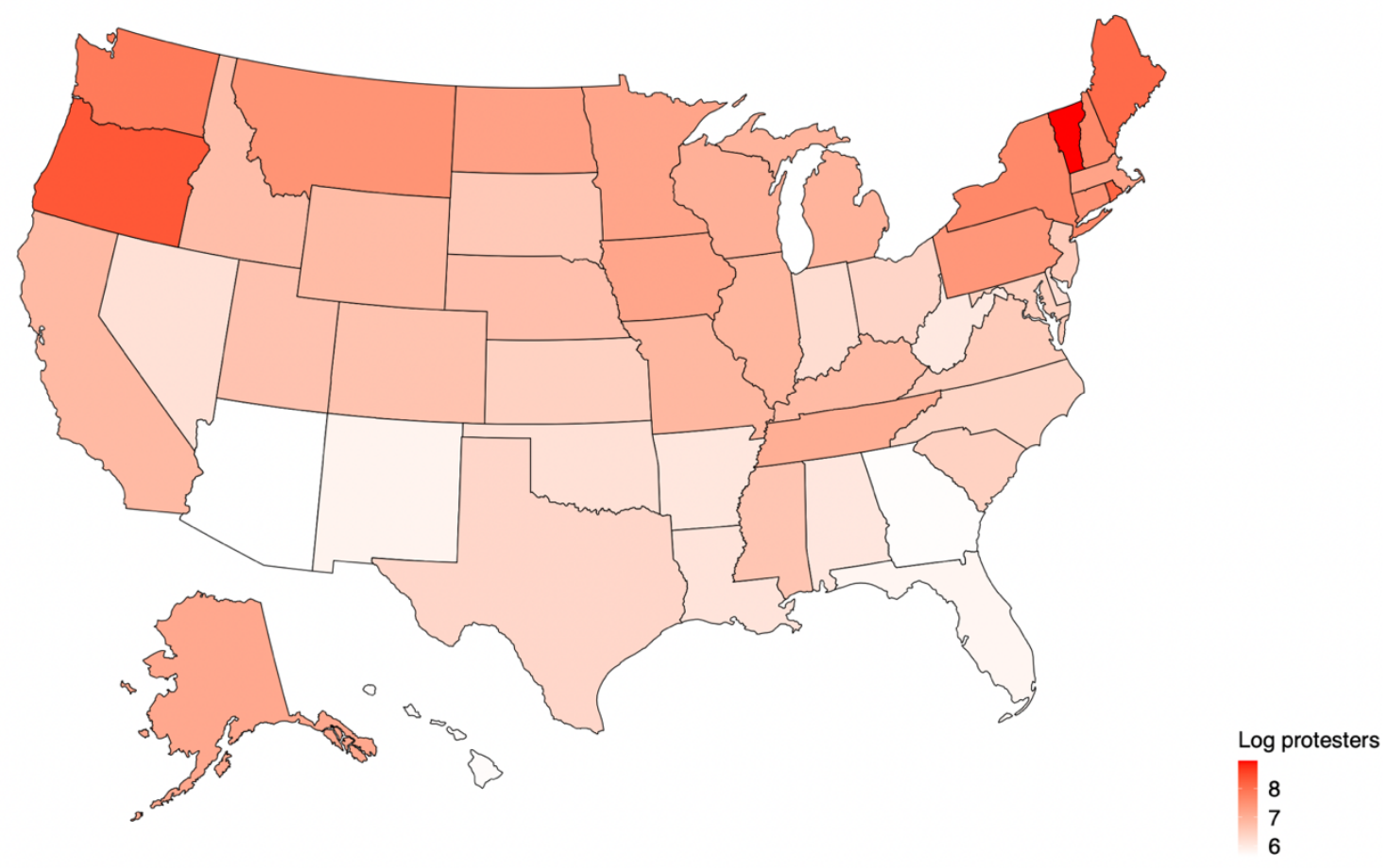

Figure 7: Log per-month number of protesters per 100,000 urban pop. by U.S. state 


\section{$4 \quad$ Data and Methods}

Our analysis is based on four sources of data. First, our protest measures derive from the largest existing quantitative dataset on political crowds reported in the United States: the Crowd Counting Consortium (CCC). It includes information on marches, protests, strikes, demonstrations, riots, and other actions. CCC, organized and orchestrated by Chenoweth and Pressman (2020), collaborates with other volunteers that used a WebCrawler to retrieve daily protest data from local newspaper and television sites. Sobolev et al. (2020) test the accuracy of the CCC data by comparing the correlation between news and geolocated social media data with cellphone location estimates, finding that CCC correlates more than any other source with cellphone data. News and social media data accurately estimate protest size variation (see mention in Teeselink and Melios forthcoming). We focus our analysis on protests that occurred during the entire period from May 25, 2020, until the 31st of December 2020. CCC data include a list of 'claims' made by the protest movement. To identify BLM protests we subset for protests whose claims match a set of BLM-related keywords (details are provided in Appendix C). We have information about the cities in which protests took place; these cities are matched to police authorities using US Census Bureau data.

Our second main source of data is an original hand-compiled dataset on police budgets of the 300 largest cities of the United States. The dataset covers the years 2018/2018, 2019/2020 and 2020/2021 and comprises data of proposed overall city budget, data of approved overall city budget, data of approved police budget, and data of proposed police budget. We further retrieved data on the approved police department personnel for the years 2019/2020 and 2020/2021. Most budget information is published on the city council websites. News articles provide hints for where to find proposals for the 
different budgets. ${ }^{2}$

Third, our state-level policy data derive from the NCSL (National Conference of State Legislatures 2021) database which provides information on law enforcement legislation that has been introduced in the 50 states and the District of Columbia. The database contains policing bills and executive orders and starts on May 25th. We investigate a total of 1,289 proposed bills from May 2020 until July 2021, across 51 state legislatures. ${ }^{3}$ Of these, 166 bills have been approved. Only two states - Idaho and North Dakota - have had no police reform bills proposed since May 2020, whereas a further ten states have proposed but failed to approve a reform bill in the same period. Fourth, we retrieve city and state-level control variables from the U.S. Census Bureau.

\subsection{Variables and Analytical Strategy}

\subsection{Dependent Variables}

At the city-level, our main dependent variable is change in the share of the city budget assigned for policing from 2019/20 to 2020/21 (measured as the percentage difference between 2019/20 to 2020/21). In some cases, police budgets grew only slightly in absolute terms but fell as a share of an increased overall city budget. For robustness, we also model changes in the number of police officers registered on police budgets (details reported in Appendix D).

At the state-level, we use two dependent variables: the number of police reform related bills proposed to state legislatures, as well as the number of bills approved or adopted by state legislatures. We thus have a means to distinguish between the effect of protest on agenda-setting - captured by the number of bills proposed - and its ability to produce substantive change-represented by

\footnotetext{
${ }^{2}$ Consult Appendix $\mathrm{C}$ for a description of the data collection process.

${ }^{3}$ We include Washington, D.C. in our main analysis, since the Council of the District of Columbia operates similarly to a state legislature. For robustness checks to show that our results remain unchanged once Washington, D.C. is excluded, see Appendix F.
} 
the number of bills approved.

\subsection{Independent Variable: Protest Size}

A fundamental assumption in scholarship on social movements is that the more people participate in protest the greater the chances of success. Yet to assess the numerical strength of protest most studies rely on the indirect measure of total number of protest events rather than the direct measure of total number of participants. Because protest event frequency and number of protest participants are weakly correlated (Biggs 2018), current knowledge about how numbers matter for protests to achieve protesters' goals remains limited. Using the number of protest participants per 100,000 population rather than the number of protest events as main independent variable leads to a better fit of the data; the R-Squared was higher for protest participants, whereas coefficients remained broadly the same. This lends credence to the robustness of our general results and demonstrates the importance of using the number of protest participants as the main independent variable (see Appendix E for results with protest events). One plausible explanation is that many participants are less likely to go unnoticed than small protest events. It is also not clear what it means to have protest events per given population. Perhaps New York hosts a few big events, which would count as little protest despite attracting large numbers of participants. In sum, taking up Biggs' call for justifying the use of protest measure, we have compelling reasons to focus on the effect of protest by focusing on the total number of participants (Biggs 2018; descriptive statistics for the protest variables used in our analysis for 288 cities in Appendix A).

At the city-level, we limit our explanatory variable to protests that occurred before city budgets were approved to ensure that the protest treatment precedes possible effects on police budgets. We exclude protests that happened after the budget approval date. Because cities approved their budgets at 
different times, we divide the pre-budget total number of protesters by the number of months elapsed from May $25^{\text {th }}$ - the start of the protest dataset to the budget approval date. This yields a measure of per-month protest. ${ }^{4}$ Finally, we divide this per-month protest measure by the total city population (in 100,000 s) to create the city-level per-month protest measure per 100,000 population.

At the state-level we aggregate the number of protest participants and divide by the number of months elapsed from May 25th until December $31^{\text {st }}$. We then divide by the state's urban population to arrive at the state-level permonth protest measure. Instead of dividing the per-month protest measure by the total state population (in 100,000s), we divide instead by the total urban state population (in 100,000s), as protest happens predominantly in urban areas.

\subsection{Omitted Variable Bias}

Like other research on the outcomes of protest, we face the difficulty that protest outcomes and protest could be explained by unobserved political preferences. One way to circumvent such concerns for endogeneity is an instrumental variable approach. The idea is to identify a variable that correlates with the outcome of interest only through its relationship with the independent variable. Rainfall is a commonly used instrumental variable to study protest (Madestam et al. 2021; Wasow 2020). It is assumed that rainfall has an influence on policymaking, public opinion, or the presidential election only through its relationship with protest. However, in the context of the BLM movement, rainfall is not only correlated with protest size, but also with Covid19 case counts which are associated with protest behavior (R. Valentine, D.

\footnotetext{
${ }^{4}$ Here, months are standardized to 30-day intervals. For illustrative purposes, we choose to use per-month rather than per-week protest.
} 
Valentine and J. Valentine 2020). Thus, using weather as an instrumental variable arguably threatens the exclusion restriction ${ }^{5}$ (see Appendix M). With respect to using weather as an instrument for changes in police spending specifically, we should further be concerned that weather correlates not only with rainfall but also with violent crime (Mellon forthcoming).

Instead of holding onto a fashionable causal identification strategy, we strengthen our simpler but more adequate regression model. To this aim, we include in our OLS regressions a large number of city and state-level control variables. We also account for city-level change in the total city budget thereby isolating the effects on police budgets. We account for the possibility that protest might have different effects on our outcome variables depending on whether protest occurs in more Republican or Democrat cities. Following most recent research revealing a relationship between protest and Covid cases $(R$. Valentine, D. Valentine and J. Valentine 2020), we also include controls for Covid deaths and Covid cases.

Budgets are not adopted at the same time across the US; some cities with particular demographic characteristics are likely to approve their budgets unusually early or unusually late. As this could confound our results, we include controls for time elapsed since May 25th and its square. We thereby account for the possibility that the timing of protest is key for its effect on policy outcomes. Crucially, we also control for distance to Minneapolis and include a dummy variable measuring whether cities are state capitals. In Appendix B we present correlation matrices for the variables used in our analysis.

\footnotetext{
${ }^{5}$ Note that in recent scholarship Teeselink and Melios (forthcoming) use weather as an instrumental variable to investigate the effects of protest on the presidential election outcomes. The relationship between precipitation and Covid-19 case counts, and the fact that Covid-19 has affected local perceptions of the Trump administration's handling of the pandemic (Hart 2021) which plausibly affected vote shares in the Presidential election - will hopefully compel the authors to include Covid-19 into their models.
} 


\subsection{Statistical Model}

We estimate linear regression models that explain changes to police budgets in terms of the number of protest participants, as well as demographic variables and other control variables. We estimate changes to police budgets for city $i$ as:

$$
Y_{i}=\beta_{0}+\beta_{1} X_{i}+\beta_{2}{ }^{\prime} Z_{i}+\beta_{3}{ }^{\prime} V_{i}+u_{i}
$$

where $Y_{i}$ is the change in police budgets for city $i$ from 2019 to 2020. $X_{i}$ denotes the total number of protesters per month per 100,000 population in city $i$. $Z_{i}$ is a vector of the controls for city $i$ including the change in police budgets from 2018 to 2019; veteran and foreign-born population shares; average household size; median age; Asian, Black, Latino and White population shares; total Covid-19 deaths; 2020 Presidential Election Democratic vote share; poverty rate; a dummy for whether city $i$ is a state capital; and the distance from Minneapolis, MN. Finally, $V i$ is a vector of measures of protest violence: number of arrests, number of police and participant injuries, and instances of property damage.

For state-level outcomes, we use a similar approach. We estimate two separate models, one for proposed and another for adopted state bills using the the number of protest participants, while also controlling for state-level demographic variables. To account for the possibility that past police reform and past crime affect subsequent reform decisions, we include control variables for past crime and the number of law enforcement officers. As we have count data for the number of bills proposed and approved, we use a Poisson regression. ${ }^{6}$ The number of adopted and pending state bills for state $j$ is estimated as

\footnotetext{
${ }^{6}$ Following Cameron and Trivedi (1990) we test for overdispersion of our data. We find no evidence for severe overdispersion. We therefore use Poisson instead of negative binominal regression.
} 


$$
\log \left(E\left[Y_{j} \mid X_{j}, Z_{j}, V_{j}\right]\right)=\gamma_{0}+\gamma_{1} X_{j}+\gamma_{2}{ }^{\prime} Z_{j}+\gamma_{3}{ }^{\prime} V_{j}+e_{j}
$$

where $Y j$ denotes the number of police reform bills adopted or proposed within the state legislature for state $j . X j$ denotes the total number of protesters per month per 100,000 urban population across that state. $Z j$ is a vector of controls for state $j$ including the veteran and foreign-born population shares; the proportion of the population who have graduated high school and the share of the population with bachelor's degrees; median age; White, Black, and Asian population shares; Covid-19 deaths per million population; poverty rate; the 2020 Presidential Election Democratic vote share; the number of violent crimes per 100,000 population in 2019 ; and the number of police officers per 100,000 population registered in state $j$. $V j$ is a vector of continuous measures of protest violence: number of arrests, number of police and participant injuries, and instances of property damage (descriptions for these variables are reported in Appendix A).

\section{$5 \quad$ Results}

\subsection{Descriptive Results}

Figure 8 indicates that the number of protesters appears unrelated to changes in the funding of municipal police budgets. The slope of the line is close to horizontal; its slight upward trajectory indicates that - if anything - larger protests are associated with increases in the percentage of the city budget allocated to police spending. Figures 9 and 10 show positive associations between monthly number of protesters and state legislative activity at the adoption and proposal stage.

The descriptive graph displayed in Figure 11 and our main regression analysis, to which we turn in the next section, investigate the relationship between protest on defunding by focusing on cities that had their budget approvals after the murder of George Floyd. The number of cities that had their budgets 
decisions before the protests is too small for serious difference in difference analysis. However, descriptively it is worth comparing cities that had their budget hearings before the murder of George Floyd to cities that had their budget hearings scheduled later. Figure 11 shows that budgets approved before the murder of George Floyd seem to follow a similar trend than those that had their budgets approved after the murder of George Floyd. If defunding did occur, we would expect the line to decrease after May 25. However, there is no obvious structural break with the beginning of the protest treatment on May 25 . We find that the lack of a visual structural break corresponds with a lack of statistically significant relationship between the budget changes before and after May 25.

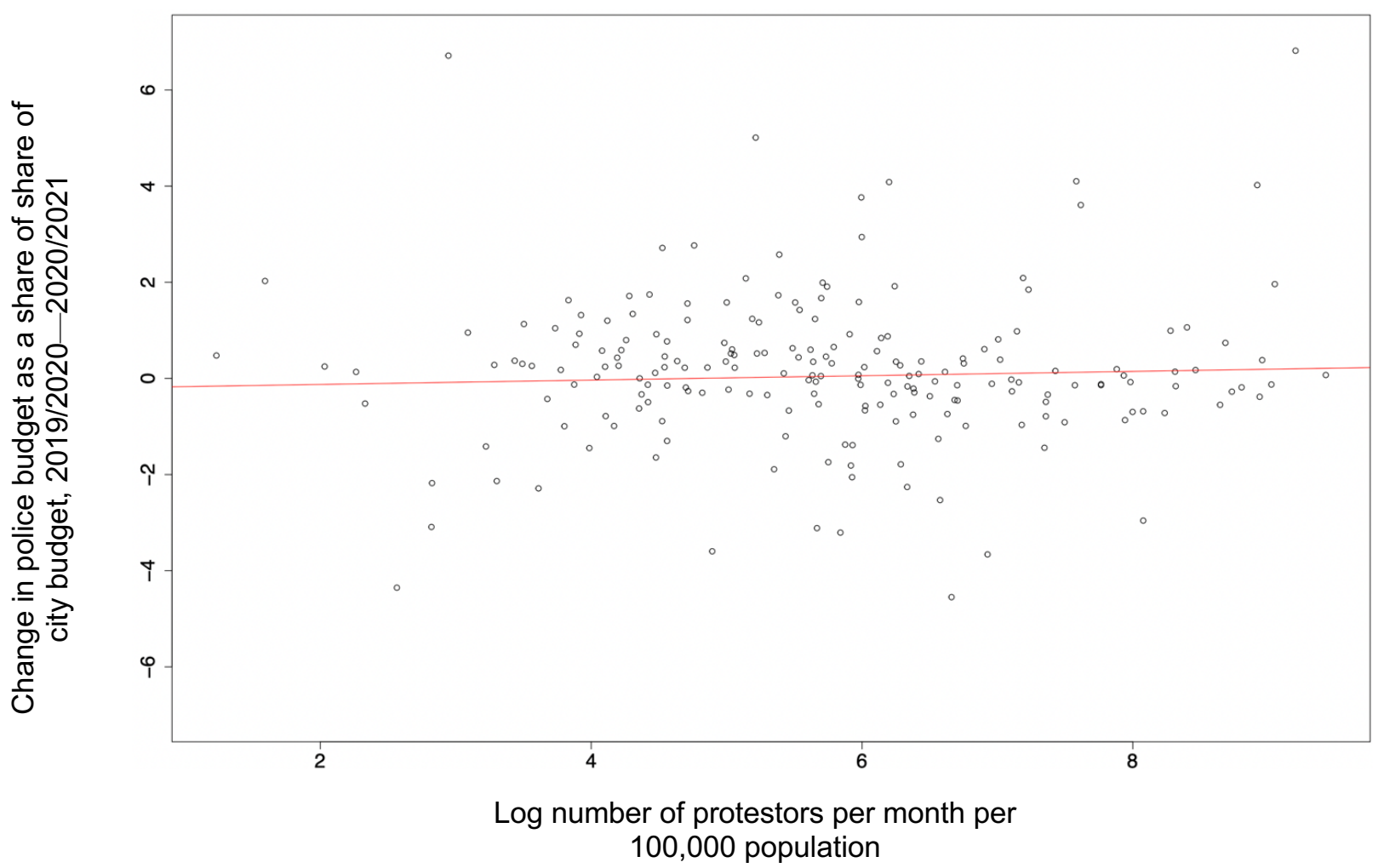

Figure 8: City-level number of protesters and change in city police budget 


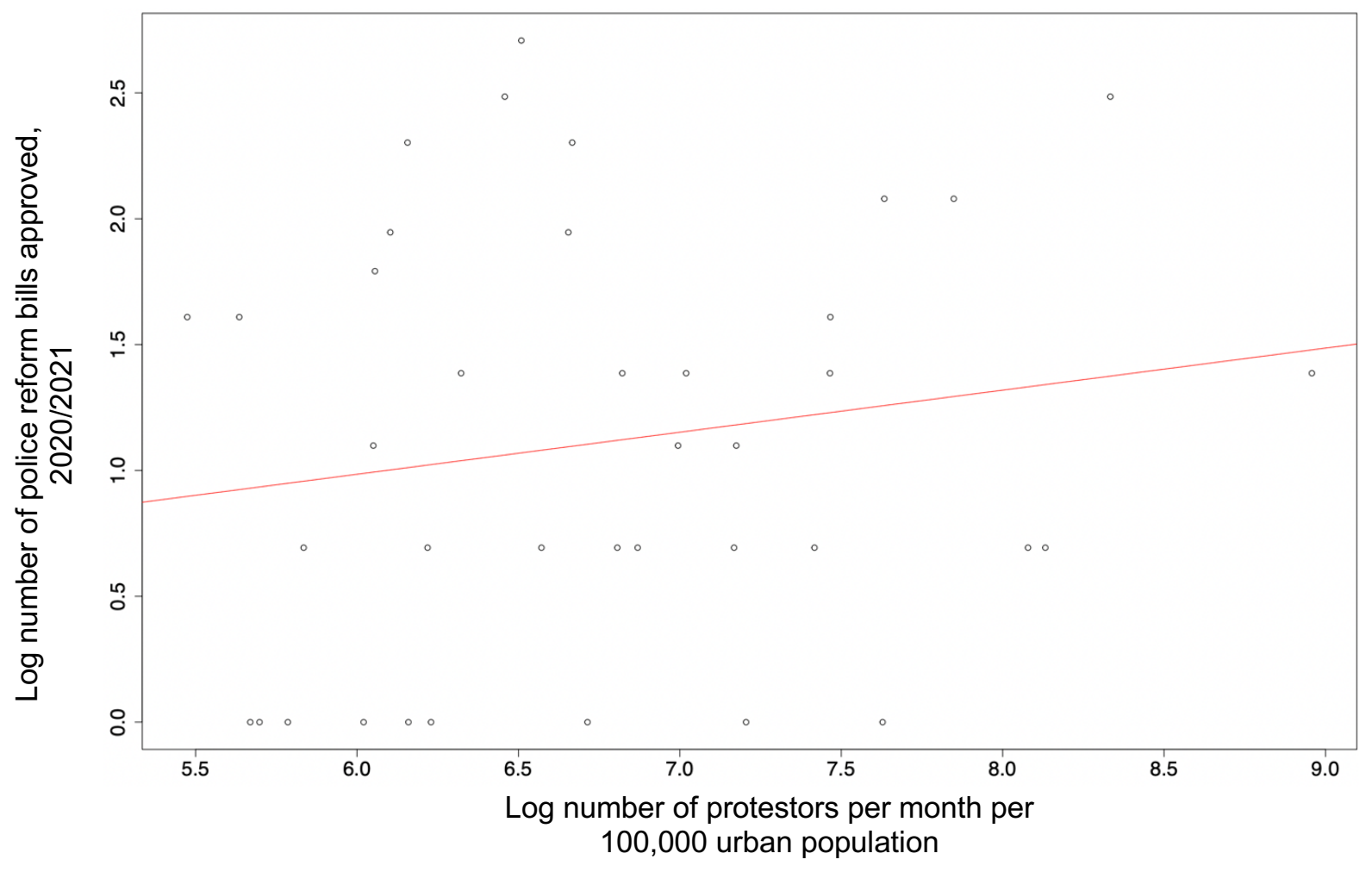

Figure 9: State-level number of protesters per urban population and adopted police reform bills

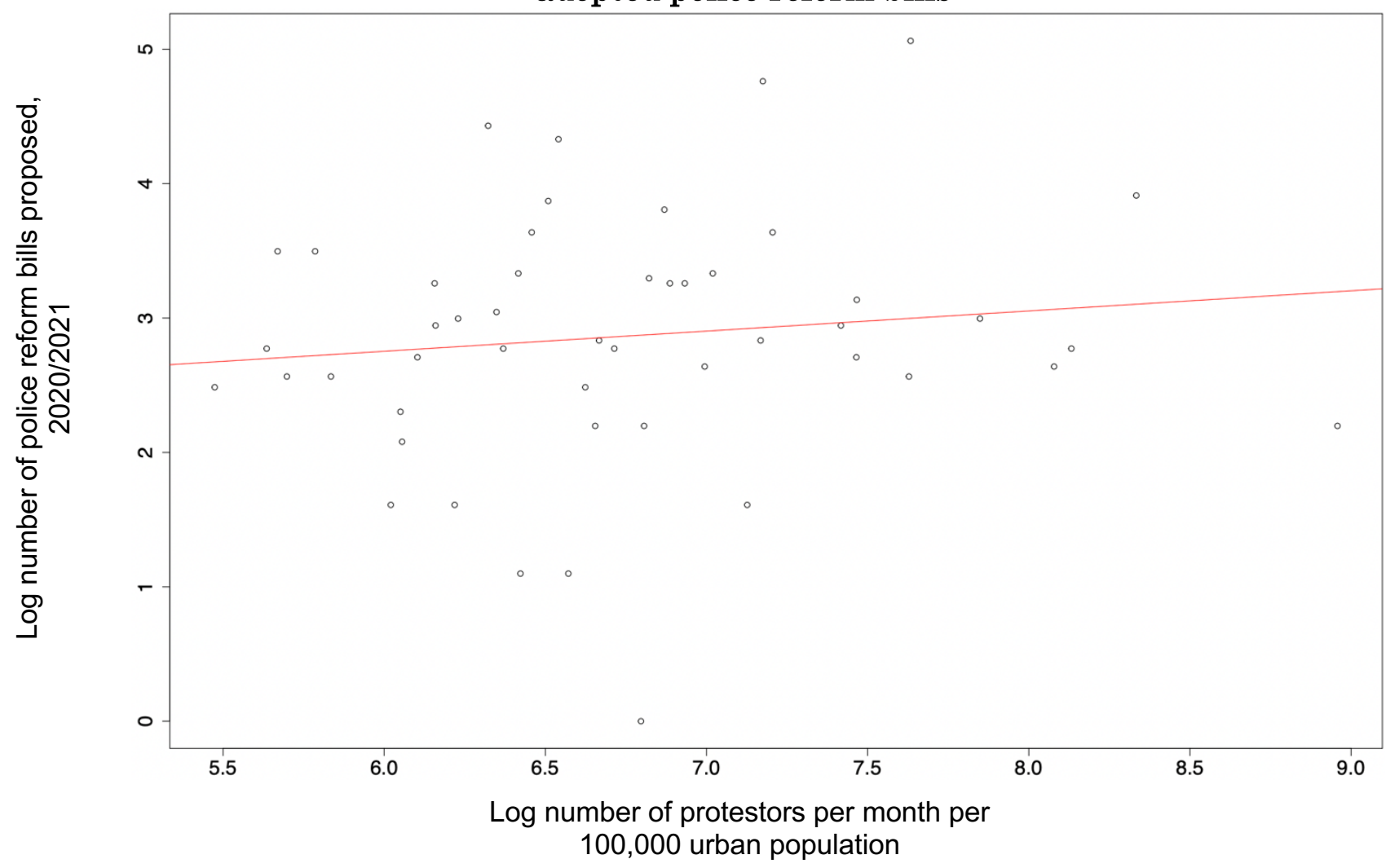

Figure 10: State-level number of protesters per urban pop. and proposed police reform bills 


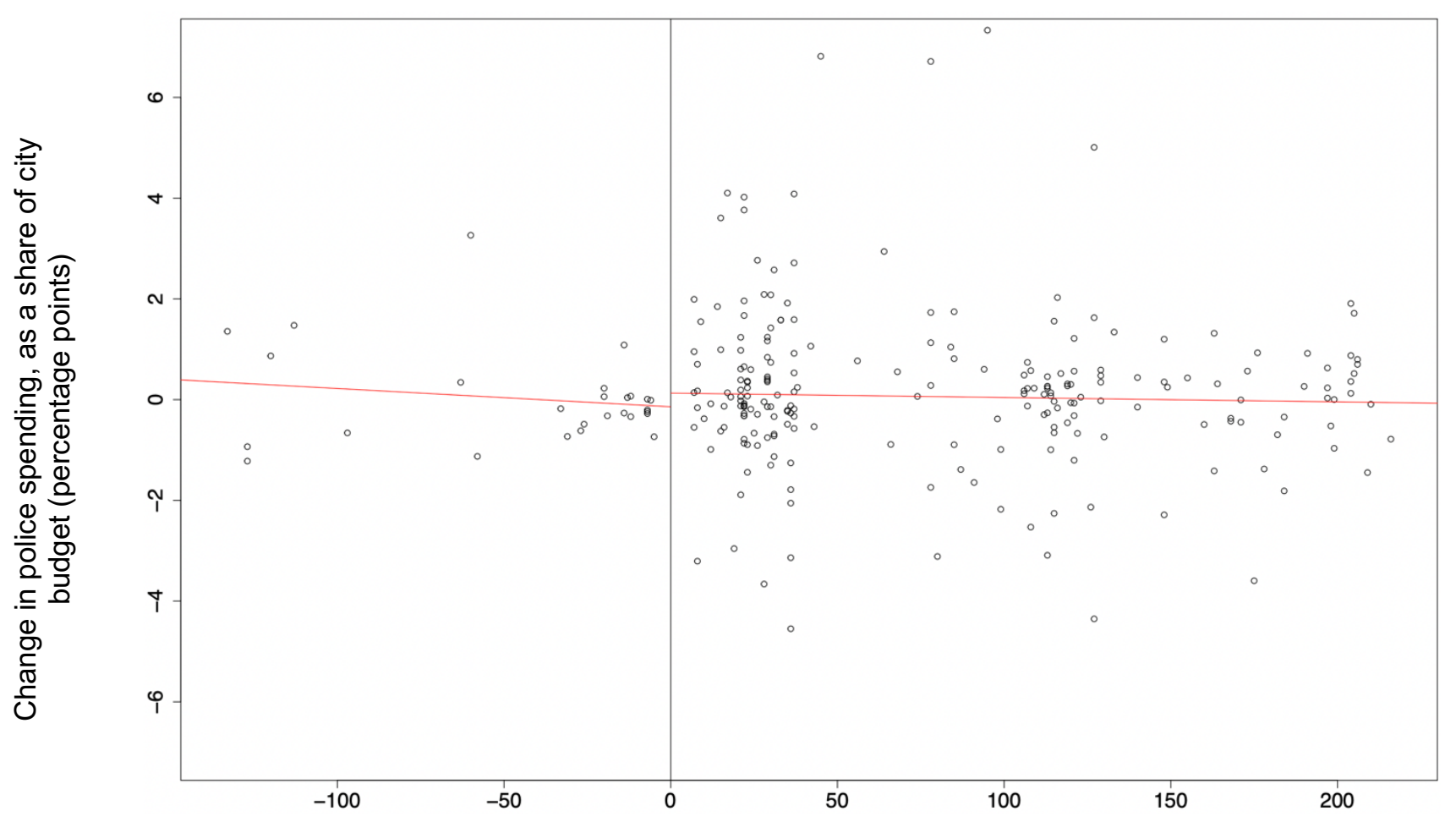

Days before or after May 25th

Figure 11: City-level date of budget approval and change in police budget as a share of city spending

\subsection{Regression Results}

\subsubsection{City-level Results}

Turning to our main regression analysis, we find that the per-month number of protesters per 100,000 population is positively but insignificantly related to changes in city police budgets. Table 2 shows that the finding of no clear relationship between the number of protesters and changes in police budgets is robust across model specifications. ${ }^{7}$ The coefficients are positive, but do not reach statistical significance at conventional levels. Thus, there may be a positive relationship between protest and increases in police budgets, but we cannot be too confident in the finding that protest was overall

\footnotetext{
${ }^{7}$ We also model the number of protesters with a quadratic term and, alternatively, as a logged variable to account for the possibility that protest is not linearly related with changes in police spending (See Appendix G and H). Results are similar to the linear models.
} 
counterproductive at the local level. To strengthen confidence in our main finding that protest is not significantly related with changes in police budgets, we repeat the analysis for the number of active police personnel. Funding for police personnel represents one core subsection of the police budget. Again, we find a weak positive, yet insignificant relationship between the number of protesters and changes in personnel funding once appropriate controls are included into the model (see regression table in Appendix D). We should caveat that our personnel measure is imperfect as it is not limited to police officers and because some cities did not release personnel data.

\begin{tabular}{|c|c|c|c|c|c|c|c|}
\hline & \multicolumn{7}{|c|}{ Change in police budget as a share of city budget, $2019 / 20-2020 / 21$} \\
\hline & (1) & (2) & (3) & $(4)$ & $(5)$ & $(6)$ & (7) \\
\hline Protesters per month per 100,000 population & 0.0001 & 0.0001 & 0.0001 & $0.0002^{+}$ & $0.0002^{+}$ & $0.0002^{+}$ & $0.0002^{+}$ \\
\hline Constant & -0.061 & -1.373 & -0.168 & 2.026 & 1.928 & 1.628 & 1.445 \\
\hline Defunding, 2018/19-2019/20 & Y & $\mathrm{Y}$ & $\mathrm{Y}$ & $\mathrm{Y}$ & Y & $\mathrm{Y}$ & $\mathrm{Y}$ \\
\hline Demographic controls & $\mathrm{N}$ & $\mathrm{Y}$ & $\mathrm{Y}$ & $\mathrm{Y}$ & $\mathrm{Y}$ & $\mathrm{Y}$ & $\mathrm{Y}$ \\
\hline Race controls & $\mathrm{N}$ & $\mathrm{N}$ & $\mathrm{Y}$ & $\mathrm{Y}$ & $\mathrm{Y}$ & $\mathrm{Y}$ & $\mathrm{Y}$ \\
\hline Poverty, Covid-19, and Dem vote share & $\mathrm{N}$ & $\mathrm{N}$ & $\mathrm{N}$ & $\mathrm{Y}$ & $\mathrm{Y}$ & $\mathrm{Y}$ & $\mathrm{Y}$ \\
\hline Protest violence controls & $\mathrm{N}$ & $\mathrm{N}$ & $\mathrm{N}$ & $\mathrm{N}$ & $\mathrm{Y}$ & $\mathrm{Y}$ & $\mathrm{Y}$ \\
\hline State capital and dist. to Minneapolis & $\mathrm{N}$ & $\mathrm{N}$ & $\mathrm{N}$ & $\mathrm{N}$ & $\mathrm{N}$ & $\mathrm{Y}$ & $\mathrm{Y}$ \\
\hline Time and time ${ }^{2}$ controls & $\mathrm{N}$ & $\mathrm{N}$ & $\mathrm{N}$ & $\mathrm{N}$ & $\mathrm{N}$ & $\mathrm{N}$ & $\mathrm{Y}$ \\
\hline$N$ & 214 & 214 & 214 & 208 & 208 & 208 & 208 \\
\hline $\mathrm{R}^{2}$ & 0.031 & 0.044 & 0.054 & 0.064 & 0.075 & 0.088 & 0.090 \\
\hline Adjusted $\mathrm{R}^{2}$ & 0.021 & 0.016 & 0.008 & 0.002 & -0.008 & -0.004 & -0.013 \\
\hline
\end{tabular}

${ }^{+} \mathrm{p}<0.1 ;{ }^{*} \mathrm{p}<0.05 ;{ }^{* *} \mathrm{p}<0.01 ;{ }^{* * *} \mathrm{p}<0.001$

Table 2: City-level number of protesters and defunding, with and without controls

\subsubsection{State-level Results}

At the state-level, we have two main dependent variables: the total number of police reform bills proposed in state legislatures during their 2020/21 sessions, and the number of bills that were approved. Results in Table 3 indicate that the number of protesters significantly contributed towards increases in the number of police reform bills that were approved by state legislatures. In Table 4 , however, we find that protest size is only insignificantly related to increases in the number of bills proposed. 


\begin{tabular}{|c|c|c|c|c|c|c|c|}
\hline & \multicolumn{7}{|c|}{ State-level number of approved police reform bills, 2020/21 } \\
\hline & (1) & (2) & (3) & (4) & (5) & (6) & (7) \\
\hline Protesters per month per 100,000 urban population & 0.0001 & $0.0003^{* *}$ & $0.0003^{* * *}$ & $0.0003^{*}$ & $0.0002^{*}$ & $0.0002^{*}$ & $0.0002^{*}$ \\
\hline Constant & $1.047^{* * *}$ & $14.427^{*}$ & 7.150 & 8.302 & 6.272 & $21.370^{+}$ & 6.324 \\
\hline Demographic controls & $\mathrm{N}$ & $\mathrm{Y}$ & $\mathrm{Y}$ & $\mathrm{Y}$ & $\mathrm{Y}$ & $\mathrm{Y}$ & Y \\
\hline Race controls & $\mathrm{N}$ & $\mathrm{N}$ & $\mathrm{Y}$ & $\mathrm{Y}$ & $\mathrm{Y}$ & $\mathrm{Y}$ & $\mathrm{Y}$ \\
\hline Poverty, Covid-19, and Dem vote share & $\mathrm{N}$ & $\mathrm{N}$ & $\mathrm{N}$ & $\mathrm{Y}$ & $\mathrm{Y}$ & $\mathrm{Y}$ & $\mathrm{Y}$ \\
\hline Protest violence controls & $\mathrm{N}$ & $\mathrm{N}$ & $\mathrm{N}$ & $\mathrm{N}$ & $\mathrm{Y}$ & $\mathrm{Y}$ & $\mathrm{Y}$ \\
\hline Violent crime, 2019 & $\mathrm{~N}$ & $\mathrm{~N}$ & $\mathrm{~N}$ & $\mathrm{~N}$ & $\mathrm{~N}$ & $\mathrm{Y}$ & $\mathrm{N}$ \\
\hline Police officers, 2019 & $\mathrm{~N}$ & $\mathrm{~N}$ & $\mathrm{~N}$ & $\mathrm{~N}$ & $\mathrm{~N}$ & $\mathrm{~N}$ & $\mathrm{Y}$ \\
\hline$N$ & 51 & 51 & 51 & 51 & 51 & 51 & 51 \\
\hline Log Likelihood & -152.960 & -127.143 & -123.485 & -123.083 & -118.806 & -113.154 & -116.788 \\
\hline $\mathrm{AIC}$ & 309.920 & 268.285 & 266.969 & 272.166 & 269.611 & 260.309 & 267.576 \\
\hline
\end{tabular}

Table 3: State-level number of protesters and approved police reform bills, with and without controls

\begin{tabular}{|c|c|c|c|c|c|c|c|}
\hline Protesters per month per 100,000 urban population & 0.00005 & 0.0001 & 0.0001 & 0.0002 & 0.0001 & 0.0002 & 0.0001 \\
\hline Demographic controls & $\mathrm{N}$ & $\mathrm{Y}$ & $\mathrm{Y}$ & $\mathrm{Y}$ & $\mathrm{Y}$ & $\mathrm{Y}$ & $\mathrm{Y}$ \\
\hline Race controls & $\mathrm{N}$ & $\mathrm{N}$ & $\mathrm{Y}$ & $\mathrm{Y}$ & Y & $\mathrm{Y}$ & Y \\
\hline Poverty, Covid-19, and Dem vote share & $\mathrm{N}$ & $\mathrm{N}$ & $\mathrm{N}$ & $\mathrm{Y}$ & Y & Y & $\mathrm{Y}$ \\
\hline Police officers, 2019 & $\mathrm{~N}$ & $\mathrm{~N}$ & $\mathrm{~N}$ & $\mathrm{~N}$ & $\mathrm{~N}$ & $\mathrm{~N}$ & $\mathrm{Y}$ \\
\hline$N$ & 51 & 51 & 51 & 51 & 51 & 51 & 51 \\
\hline Log Likelihood & -684.168 & -476.557 & -435.781 & -428.281 & -364.778 & -349.595 & -353.396 \\
\hline $\mathrm{AIC}$ & $1,372.337$ & 967.114 & 891.561 & 882.562 & 761.557 & 733.190 & 740.792 \\
\hline
\end{tabular}

${ }^{+} \mathrm{p}<0.1 ;{ }^{*} \mathrm{p}<0.05 ;{ }^{* *} \mathrm{p}<0.01 ;{ }^{* * *} \mathrm{p}<0.001$

Table 4: State-level number of protesters and proposed police reform bills, with and without controls.

\subsubsection{Interaction Models}

At the city-level, number of protesters has no significant relationship with changes in police budgets. If anything, protest may have been counterproductive. We turn to a more detailed analysis of the relationship between protest size and changes in police budgets, by focusing on three possible sources of heterogeneity. To assess whether protest exerts greater influence in some cities than in others we interact our protest variable with poverty rate, black population share, and Democratic vote share. In Table 5 we find neither an effect for protest on city-level police spending, nor for the interaction between protest and poverty. Figure 12 graphically depicts the lack of a significant relationship between the number of protesters and defunding of police budgets at varying levels of poverty. 


\begin{tabular}{|c|c|c|c|c|c|c|c|}
\hline & \multicolumn{7}{|c|}{ Change in police budget as a share of city budget, $2019 / 20-2020 / 21$} \\
\hline & (1) & (2) & (3) & (4) & (5) & (6) & (7) \\
\hline Protesters per month per 100,000 population & -0.00004 & -0.00000 & 0.00000 & 0.0001 & 0.0001 & 0.0001 & 0.0002 \\
\hline Poverty rate & -0.040 & -0.034 & -0.027 & -0.033 & -0.025 & -0.022 & -0.020 \\
\hline Protesters $\times$ poverty rate & 0.00001 & 0.00001 & 0.00001 & 0.00001 & 0.00000 & 0.00000 & 0.00000 \\
\hline Constant & 0.485 & 0.115 & 0.710 & 1.897 & 1.859 & 1.577 & 1.400 \\
\hline Defunding, 2018/19 - 2019/20 & $\mathrm{Y}$ & $\mathrm{Y}$ & $\mathrm{Y}$ & $\mathrm{Y}$ & $\mathrm{Y}$ & $\mathrm{Y}$ & $\mathrm{Y}$ \\
\hline Demographic controls & $\mathrm{N}$ & $\mathrm{Y}$ & $\mathrm{Y}$ & $\mathrm{Y}$ & $\mathrm{Y}$ & $\mathrm{Y}$ & $\mathrm{Y}$ \\
\hline Race controls & $\mathrm{N}$ & $\mathrm{N}$ & $\mathrm{Y}$ & $\mathrm{Y}$ & $\mathrm{Y}$ & $\mathrm{Y}$ & $\mathrm{Y}$ \\
\hline Covid-19, and Dem vote share & $\mathrm{N}$ & $\mathrm{N}$ & $\mathrm{N}$ & $\mathrm{Y}$ & $\mathrm{Y}$ & $\mathrm{Y}$ & $\mathrm{Y}$ \\
\hline Protest violence controls & $\mathrm{N}$ & $\mathrm{N}$ & $\mathrm{N}$ & $\mathrm{N}$ & $\mathrm{Y}$ & $\mathrm{Y}$ & $\mathrm{Y}$ \\
\hline State capital and dist. to Minneapolis & $\mathrm{N}$ & $\mathrm{N}$ & $\mathrm{N}$ & $\mathrm{N}$ & $\mathrm{N}$ & $\mathrm{Y}$ & $\mathrm{Y}$ \\
\hline Time and time ${ }^{2}$ controls & $\mathrm{N}$ & $\mathrm{N}$ & $\mathrm{N}$ & $\mathrm{N}$ & $\mathrm{N}$ & $\mathrm{N}$ & $\mathrm{Y}$ \\
\hline$N$ & 214 & 214 & 214 & 208 & 208 & 208 & 208 \\
\hline $\mathrm{R}^{2}$ & 0.040 & 0.049 & 0.057 & 0.065 & 0.075 & 0.088 & 0.090 \\
\hline Adjusted $\mathrm{R}^{2}$ & 0.022 & 0.011 & 0.001 & -0.003 & -0.013 & -0.009 & -0.018 \\
\hline
\end{tabular}

Table 5: City-level number of protestors and defunding, with an interaction term for poverty rate

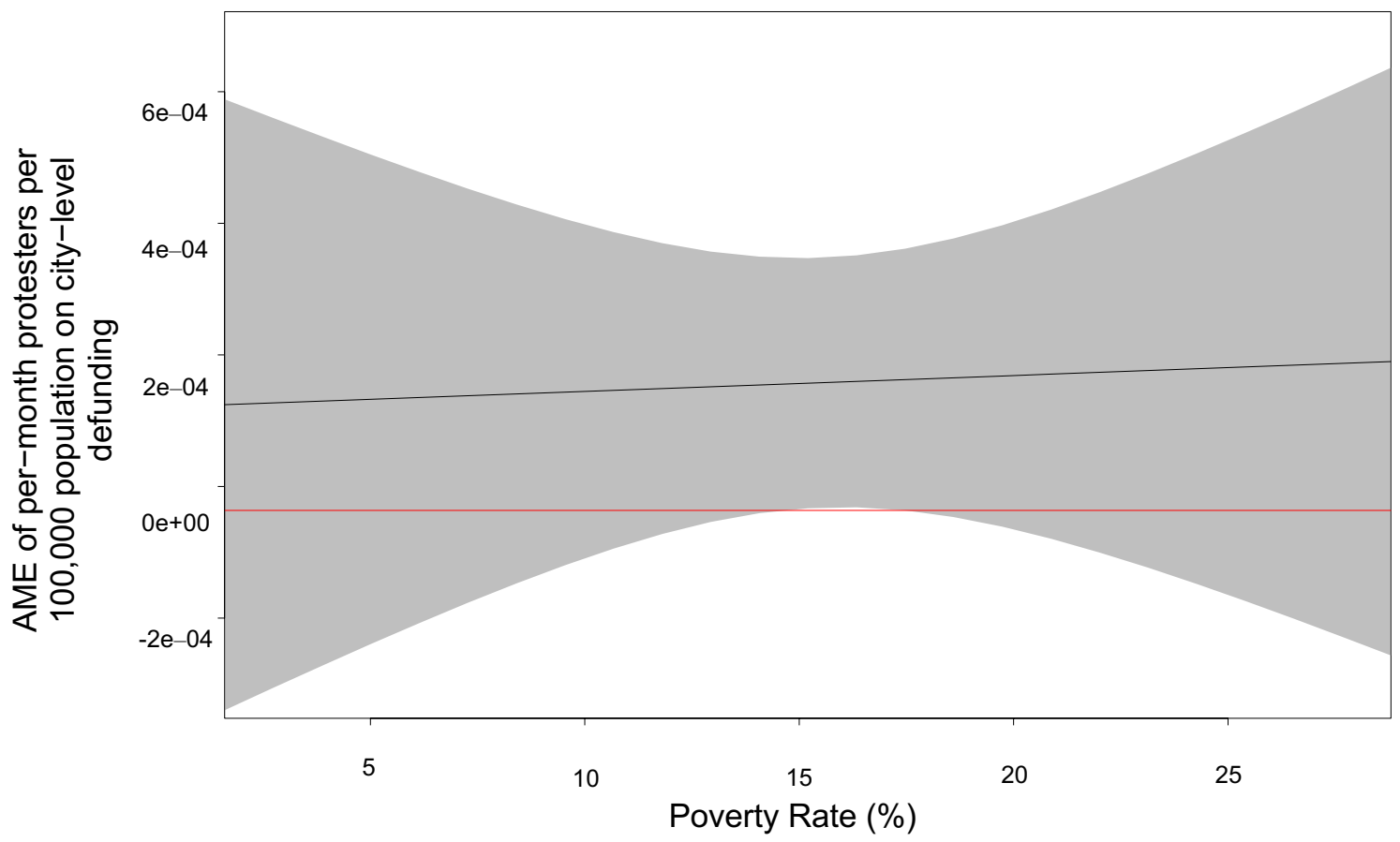

Figure 12: Average marginal effect of protestors per month per 100,000 population on change in police budget as share of city budget, 2019/20$2020 / 2021$, at varying levels of poverty rate

Table 6 tentatively shows that in cities with larger black population shares the number of protesters is associated with greater decreases in police budgets than in cities with large white population shares. The interaction effect does not quite reach conventional levels of statistical significance. The average 
marginal effects of protesters on change in police budget as share of city budget help to decide whether protest was overall effective or ineffective depending on the size of the black population shares. Figure 13 shows that in cities with a large white population share the number of protesters is positively associated with increases in city police budgets. However, the reverse is not true. Even in cities with the highest levels of Black population share we cannot be confident that protest produced significant effects on defunding. The reason may be statistical rather than substantive; the number of observations for predominantly black cities is small.

\begin{tabular}{|c|c|c|c|c|c|c|c|}
\hline & \multicolumn{7}{|c|}{ Change in police budget as a share of city budget, 2019/20 - 2020/21 } \\
\hline & (1) & $(2)$ & (3) & (4) & $(5)$ & $(6)$ & (7) \\
\hline Protesters per month per 100,000 population & 0.0002 & $0.0002^{+}$ & $0.0002^{+}$ & $0.0003^{*}$ & $0.0003^{*}$ & $0.0003^{*}$ & $0.0003^{*}$ \\
\hline Black population share & 0.144 & 0.574 & -0.284 & 0.498 & 0.286 & 0.287 & -0.012 \\
\hline Protesters $\times$ Black population share & -0.001 & -0.001 & $-0.001^{+}$ & -0.001 & $-0.001^{+}$ & $-0.001^{+}$ & $-0.001^{+}$ \\
\hline Constant & -0.075 & -1.378 & 0.104 & 2.214 & 2.157 & 1.772 & 1.722 \\
\hline Defunding, 2018/19 - 2019/20 & $\mathrm{Y}$ & $\mathrm{Y}$ & $\mathrm{Y}$ & $\mathrm{Y}$ & $\mathrm{Y}$ & $\mathrm{Y}$ & $\mathrm{Y}$ \\
\hline Demographic controls & $\mathrm{N}$ & $\mathrm{Y}$ & $\mathrm{Y}$ & $\mathrm{Y}$ & $\mathrm{Y}$ & $\mathrm{Y}$ & $\mathrm{Y}$ \\
\hline Race controls & $\mathrm{N}$ & $\mathrm{N}$ & $\mathrm{Y}$ & $\mathrm{Y}$ & $\mathrm{Y}$ & $\mathrm{Y}$ & $\mathrm{Y}$ \\
\hline Poverty, Covid-19, and Dem vote share & $\mathrm{N}$ & $\mathrm{N}$ & $\mathrm{N}$ & $\mathrm{Y}$ & $\mathrm{Y}$ & $\mathrm{Y}$ & $\mathrm{Y}$ \\
\hline Protest violence controls & $\mathrm{N}$ & $\mathrm{N}$ & $\mathrm{N}$ & $\mathrm{N}$ & $\mathrm{Y}$ & $\mathrm{Y}$ & $\mathrm{Y}$ \\
\hline State capital and dist. to Minneapolis & $\mathrm{N}$ & $\mathrm{N}$ & $\mathrm{N}$ & $\mathrm{N}$ & $\mathrm{N}$ & $\mathrm{Y}$ & $\mathrm{Y}$ \\
\hline Time and time ${ }^{2}$ controls & $\mathrm{N}$ & $\mathrm{N}$ & $\mathrm{N}$ & $\mathrm{N}$ & $\mathrm{N}$ & $\mathrm{N}$ & $\mathrm{Y}$ \\
\hline$N$ & 214 & 214 & 214 & 208 & 208 & 208 & 208 \\
\hline $\mathrm{R}^{2}$ & 0.038 & 0.050 & 0.061 & 0.071 & 0.083 & 0.098 & 0.099 \\
\hline Adjusted $\mathrm{R}^{2}$ & 0.020 & 0.012 & 0.010 & 0.003 & -0.004 & 0.001 & -0.008 \\
\hline
\end{tabular}

Table 6: City-level number of protestors and defunding, with an interaction term for black population share 


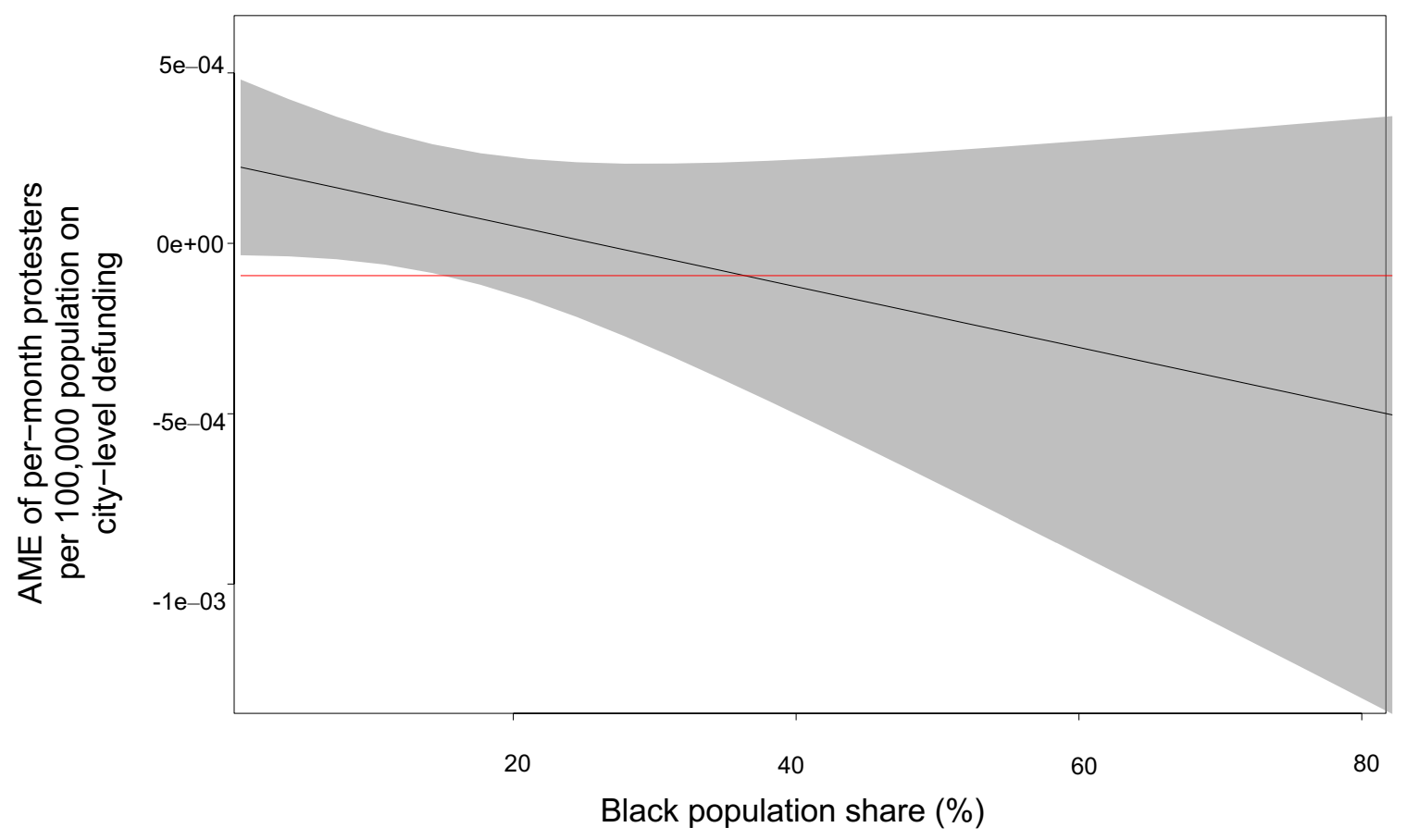

Figure 13: Average marginal effect of protestors per month per 100,000 population on change in police budget as share of city budget, 2019/20$2020 / 21$, at varying levels of black population share

Table 7 shows that the number of protesters in Democratic cities is associated with greater decreases in police budgets than in Republican cities. To reveal whether this implies that larger protests were overall unsuccessful in Republican places we present the marginal effect of protesters per month per 100,000 population at varying levels of Democratic vote share in Figure 14. The figure shows that bigger protests were counterproductive in cities where the Democratic vote share was smaller than $65 \%$. In strong Republican cities with a Democratic vote share of $30 \%$, for example, an increase of 1,000 protesters per 100,000 population is linked to a 7-percentage point increase in the police share of city budgets. The graph also shows that even in cities with the greatest Democratic vote share, the number of protesters is only insignificantly associated with decreases in police budgets. 


\begin{tabular}{|c|c|c|c|c|c|c|c|}
\hline & \multicolumn{7}{|c|}{ Change in police budget as a share of city budget, 2019/20 - 2020/21 } \\
\hline & $(1)$ & $(2)$ & (3) & $(4)$ & $(5)$ & $(6)$ & $(7)$ \\
\hline Protesters per month per 100,000 population & $0.001^{*}$ & $0.001^{* *}$ & $0.001^{* *}$ & $0.001^{* *}$ & $0.001^{* *}$ & $0.001^{* *}$ & $0.001^{* *}$ \\
\hline 2020 Presidential Election Dem vote share & 0.424 & 0.353 & -0.686 & -0.485 & -0.540 & -0.207 & -0.057 \\
\hline Protesters $\times$ Dem vote share & $-0.001^{* *}$ & $-0.001^{* *}$ & $-0.001^{*}$ & $-0.001^{* *}$ & $-0.001^{*}$ & $-0.001^{* *}$ & $-0.001^{* *}$ \\
\hline Constant & -0.339 & -1.636 & -0.178 & 1.759 & 1.661 & 1.579 & 1.126 \\
\hline Defunding, 2018/19 - 2019/20 & $\mathrm{Y}$ & $\mathrm{Y}$ & $\mathrm{Y}$ & $\mathrm{Y}$ & $\mathrm{Y}$ & $\mathrm{Y}$ & $\mathrm{Y}$ \\
\hline Demographic controls & $\mathrm{N}$ & $\mathrm{Y}$ & $\mathrm{Y}$ & $\mathrm{Y}$ & $\mathrm{Y}$ & $\mathrm{Y}$ & $\mathrm{Y}$ \\
\hline Race controls & $\mathrm{N}$ & $\mathrm{N}$ & $\mathrm{Y}$ & $\mathrm{Y}$ & $\mathrm{Y}$ & $\mathrm{Y}$ & $\mathrm{Y}$ \\
\hline Poverty and Covid-19 & $\mathrm{N}$ & $\mathrm{N}$ & $\mathrm{N}$ & $\mathrm{Y}$ & $\mathrm{Y}$ & $\mathrm{Y}$ & $\mathrm{Y}$ \\
\hline Protest violence controls & $\mathrm{N}$ & $\mathrm{N}$ & $\mathrm{N}$ & $\mathrm{N}$ & $\mathrm{Y}$ & $\mathrm{Y}$ & $\mathrm{Y}$ \\
\hline State capital and dist. to Minneapolis & $\mathrm{N}$ & $\mathrm{N}$ & $\mathrm{N}$ & $\mathrm{N}$ & $\mathrm{N}$ & $\mathrm{Y}$ & $\mathrm{Y}$ \\
\hline Time and time ${ }^{2}$ controls & $\mathrm{N}$ & $\mathrm{N}$ & $\mathrm{N}$ & $\mathrm{N}$ & $\mathrm{N}$ & $\mathrm{N}$ & $\mathrm{Y}$ \\
\hline$N$ & 213 & 213 & 213 & 208 & 208 & 208 & 208 \\
\hline $\mathrm{R}^{2}$ & 0.046 & 0.057 & 0.073 & 0.080 & 0.089 & 0.103 & 0.107 \\
\hline Adjusted $\mathrm{R}^{2}$ & 0.027 & 0.020 & 0.017 & 0.013 & 0.002 & 0.007 & 0.001 \\
\hline
\end{tabular}

${ }^{+} \mathrm{p}<0.1 ;{ }^{*} \mathrm{p}<0.05 ;{ }^{* *} \mathrm{p}<0.01 ;{ }^{* * *} \mathrm{p}<0.001$

Table 7: City-level number of protestors and defunding, with an interaction term for Democratic vote share

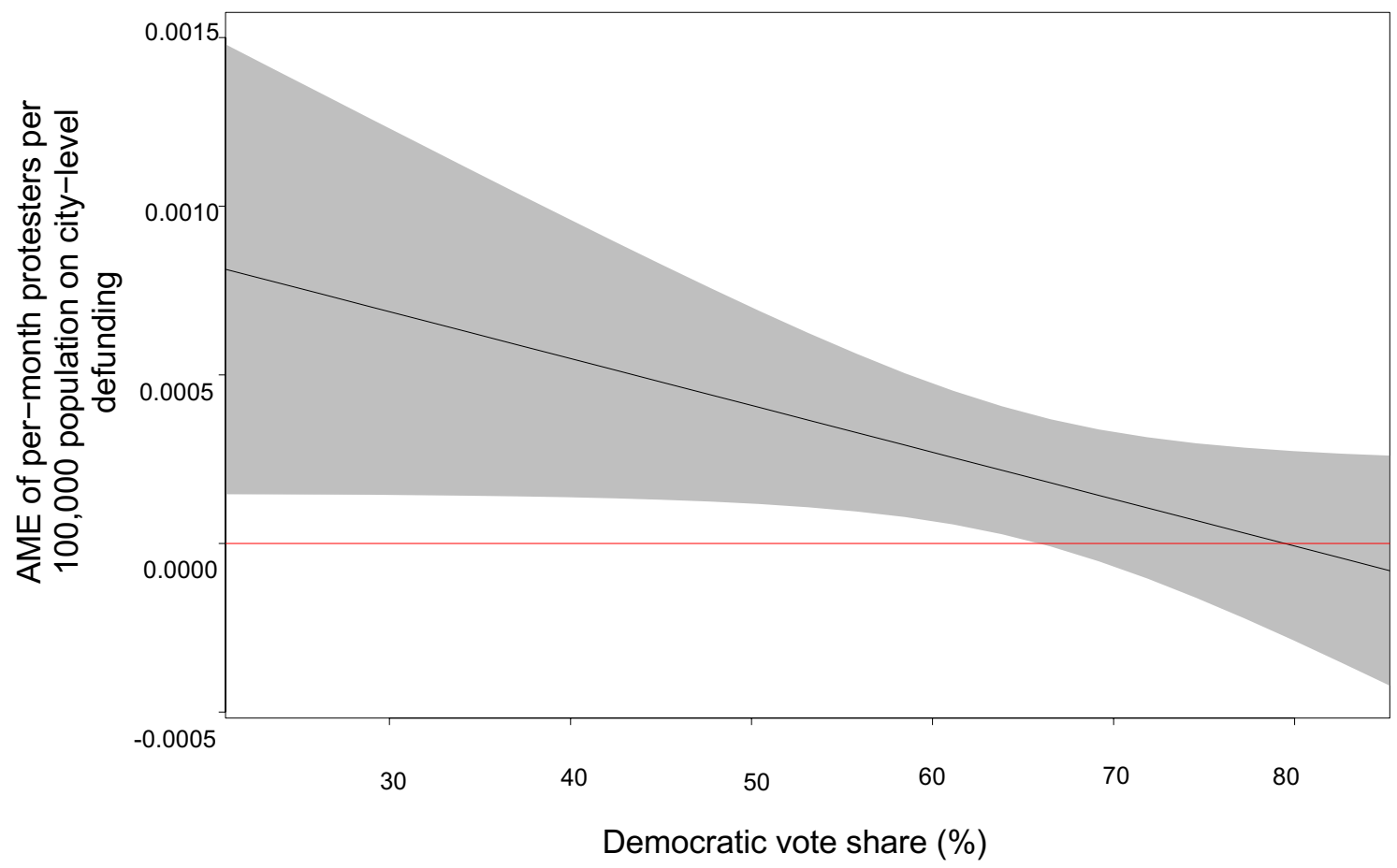

Figure 14: Average marginal effect of protestors per month per 100,000 population on change in police budget as share of city budget, 2019/202020/21, at varying levels of Democratic vote share

The results from our interaction models align with our general argument about how protest may cause policy outcomes. The effects of the Black Lives Matter protests did not depend on the levels of poverty, perhaps because poor people only pose a limited political threat to policymakers. When audiences were 
favorable to defunding, that is in cities with more black people and greater Democratic vote share, protest did not lead to defunding, but it led to less increases in police budgets than in cities with fewer Democrats and fewer black people. Protest was probably counterproductive in cities that were predominantly white and Republican.

\section{Discussion}

Before reiterating the main findings of our analysis a few limitations are in order. First, our study focuses on the immediate effects of protest. Policy processes take time, and protest might exert its influence in the future. Case studies reveal that policymakers were able to respond to protest in the 2020 budget cycle. Our findings that protest was unrelated to reductions in police budgets and was probably actively counterproductive in Republican and predominantly white cities offer important evidence on the immediate effects of protest. However, in line with Dorf and Tarrow's (2014) findings that movements can bring about change through responses to countermobilization, the demand to defund the police may be in its infancy. Initial protest at the city-level may have caused immediate backlash, which can spark future activism to bring about social change. By contrast, protest at the state-level led to the realization of the more moderate demand for police reform in the immediate aftermath of protest. It may, however, not lead to backlash, instead getting incorporated into institutionalized political routines, which prevents future mobilization. Our findings may thus hint at an interesting tradeoff: radical demands may be less likely to illicit immediate concessions but could cause countermobilization which has greater long-term effects than moderate demands. Moderate demands may lead to immediate, yet moderate concessions that do not spark future unrest. It is the task of future scholarship to assess the dynamics of mobilization and countermobilization in the context of the Black Lives Matter movement. 
Second, our analysis is quantitative. Qualitative research will be necessary to reveal the micro-level social mechanisms that link protest activity to policy outcomes. The authors of this article are currently preparing a follow-up study in which city council members will be interviewed to understand the individual motives which drove political responses to protest or a lack thereof.

Third, our study only focuses on two major outcome variables: police budget changes and police reform. But movements can have a broad range of influence, some of which may still be felt years after the events (Mazumder 2018; Biggs, Barrie, and Andrews 2020; Andrews, Beyerlein, and Farnum 2016). Gamson's (1975) famous definition of movement success as success in procuring new advantages has been criticized because many movement goals are so broad that it can be impossible to realize all of them. We therefore follow Andrews (2001) by focusing on outcomes rather than successes. The distinction is subtle. Often outcomes and successes are indeed synonymous, but not always. Protests can have unintended consequences. Focusing on outcomes also allowed us to treat response itself as a policy outcome, without having to classify this as successful or unsuccessful (McAdam and Su 2002). We considered that agenda setting processes led to discussions of policy proposals, but not necessarily to their adoption (B. King et al. 2005). Not least, it is not our aim to venture normative claims about the overall success or failure of the BLM movement, but to reveal whether core demands at both the local and state-level were realized.

Finally, we focus on outcomes that are similar at local, and state-level. Yet, changes in police budgets are considered more radical and differ from police reform. Depending on the type of police reform, defunding may even hinder police reform. To test our theoretical argument more directly, we encourage future research to engage in the cumbersome task of collecting data on local police reform. At the time of inception of this research, these data were not 
available.

This leads to a broader point about data on local politics. No centralized database on local politics exists. Political scientists have highlighted this problem, but calls have remained largely unanswered. The main reason for the lack of scholarly evidence on the relationship between local politics and protest lies in a lack of systematic data that is publicly accessible (Trounstine 2009). Facing this challenge, we constructed a novel data set on police budgets in the 300 largest cities which allows us to study the relationship between protest and local policymaking. We hope that the data collected for this analysis will prove useful for future scholarship on local politics. We are however under no illusion that it is only a first step in providing local data for comprehensively studying local politics and the local outcomes of protest. A unified source of data on local politics is eagerly awaited.

Our analysis offers first empirical evidence that protest might work differently depending on which political level is targeted. We find that in the short term protest probably did not lead to substantive changes in municipal police budgets. If anything, Black Lives Matter protests may have caused increases in city police budgets. We further investigated our null findings for the effect of protest on defunding. We find that, while overall ineffective, protest was actively counterproductive in Republican and white cities. At the state-level, protest is associated with an increase in the adoption of police reform legislation but has not led to more legislative proposals. Our results challenge existing findings that protest can bring about political change at the agenda setting stage but is less successful at the adoption stage in the policymaking process.

In the context of local politics, the disruptive costs of protest may explain the main finding that protest did not change municipal police budgets. 
Persuasion through direct interaction did not seem to prove compelling enough to outweigh other political considerations. In black and Democratic cities, where political incentives to make concessions exist, policymakers are at least not responding with policy that is actively counterproductive - an outcome we observe in predominately white and Republican cities. Most research that focuses on state outcomes relies on the assumption that protest works through electoral incentives. At the state-level it may be more important to have large protests with many participants to attract widespread media attention, which matter for the chances of policymakers' electoral success. The unusually high saliency of Black Lives Matter and the fact that protests and elections coincided may have offered protesters more leverage to force politicians to concede concessions. The political threat, to use the conceptual vocabulary of this article, may have pushed state politicians to concessions that policymakers were unwilling to make at the local level where protesters lack bargaining power and where the immediate threat of protest could hinder protesters to achieve their goals.

Our finding that protest led to the adoption of police reform runs counter to previous scholarship that found effects at the agenda setting, but not the adoption stage in the policymaking process. How can this divergence be explained? One possibility is that agenda setting responds to national level protest but is insensitive to more local dynamics. The locality of protest might matter more for realizing policy change as state policymakers are directly accountable to their state constituencies. To assess whether agenda setting is influenced by national dynamics, scholars can turn to federal level outcomes of the Black Lives Matter protests.

Indeed, to pave the way for this research and to put our results into context, we hand-collected data on federal police reform from GovTrack, an online platform that publishes and categorizes the status of federal level 
policymaking. We matched the categories for bills from the 116th Congress with those that we used for our analysis at the state-level. Of the 194 federal bills that were proposed between 2019 and 2021, 6 were approved before 25 May 2020, and no laws were approved following the BLM protests. Whereas this brief description shows that protest did not lead to the adoption of police reform, it may have led to the proposal of police reform. Future research would do well to conduct time series analysis to analyze the effect of protest on the proposal of federal level bills. This would be a direct test of the assumption that protest matters at the agenda setting stage and promises to reveal an interesting divergence between state and federal level outcomes of protest.

The consensus in mainstream political science is that all politics are increasingly nationalized. Ironically, our findings suggest that this very fact may produce different effects of protest at different levels of policymaking. The nationalization of local politics limits the electoral incentives of local policymakers to respond to protest in anticipation of political threat. At the same time, protest does impose direct costs, something we coined immediate threat.' Immediate threat may be greater the smaller the unit of political representation. There is no general law about the effect of protest on policymaking. Instead, protest matters differently at different levels of political decision making. Protest might be successful at changing state legislation, and unsuccessful in affecting local politics. Future research would do well to assess the generalizability of these findings.

Finally, our study is of relevance not only to scholars but will be of interest to activists and the wider public. The BLM protests have sparked vivid discussion whether the protests failed or succeeded. Although it is not our role to venture normative assessments on the success or failure of the recent Black Lives Matter protests, our findings suggest that neither side of the debate may have it right. Protest probably did not lead to decreases in police budgets and 
can by this metric be considered unsuccessful, but we present evidence that protest led to state-level police reform. In this sense the 2020 Black Lives Matter protests can be considered successful. 


\section{References}

Andrews, Kenneth T. 2001. "Social movements and Policy Implementation: The Mississippi Civil Rights Movement and the War on Poverty." American Sociological Review 66(1):71-95.

Andrews, Kenneth T., Kraig Beyerlein, and Tuneka T. Farnum. 2016. "The Legitmacy of Protest: Explaining White Southerners' Attitudes Towards the Civil Rights Movement." Social Forces 94(3):1021-1044.

Andrews, Kenneth T. and Neal Caren. 2010. "Making the News: Movement Organization, Media Attention, and the Public Agenda." American Sociological Review 75(6):841-866.

Andrews, Kenneth T., Neal Caren, and Alyssa Browne. 2018. "Protesting Trump." Mobilization 23(4):393-400.

Anzia, Sarah F. 2021. "Party and Ideology in American Local Government." Annual Review of Political Science 24(1):133-150.

Baumgartner, Frank R. and Bryan D. Jones. 1993. Agendas and Instability in American Politics. Chicago, IL: University of Chicago Press.

Baumgartner, Frank R. and Christine Mahoney. 2005. "Social Movements, the Rise of New Issues, and the Public Agenda." Pp. 65-86 in Routing the Opposition: Social Movements, Public Policy, and Democracy, edited by David Meyer, Valerie Jenness, and Helen Ingram. Minneapolis, MN: University of Minnesota Press.

Benedictis-Kessner, Justin and Christopher Warshaw. 2016. "Mayoral Partisanship and Municipal Fiscal Policy." The Journal of Politics 78(4):1124-1138.

Benedictis-Kessner, Justin and Christopher Warshaw. 2020. "Politics in Forgotten Governments: The Partisan Composition of County Legislatures and County Fiscal Policies." The Journal of Politics $82(2): 460-475$.

Biggs, Michael. 2018. "Size Matters: Quantifying Protest by Counting Participants.” Sociological Methods and Research 47(3):351-3833. 
Biggs, Michael and Kenneth T. Andrews. 2015. "Protest Campaigns and Movement Success: Desegregating the US South, 1960-61." American Sociological Review 80(2):416-443.

Biggs, Michael, Christopher Barrie, and Kenneth T. Andrews. 2020. "Did Local Civil Rights Protest Liberalize Whites' Racial Attitudes?" Research and Politics 7(3):1-8.

Black Lives Matter. 2020. "About - Black Lives Matter." (https://blacklivesmatter. com/about).

Buchanan, Larry, Quoctrung Bui, and Jugal K. Patel. 2020. "Black Lives Matter May Be the Largest Movement in U.S. History." The New York Times, July 3.

(https://www.nytimes.com/interactive/2020/07/03/us/george-floydprotests-crowd-size.html).

Cameron, Colin and Pravin K. Trivedi. 1990. "Regression-Based Tests for Overdispersion in the Poisson Model." Journal of Econometrics 46(3):347-364.

Chenoweth, Erica and Jeremy Pressman. 2020. "May - July 2020 Crowd Data." Crowd Counting Consortium. (https://sites.google.com/view/crowdcountingconsortium/viewdownload-the-data?authuser $=0$ )

Collins, Randall. 2004. Interaction Ritual Chains. Princeton, NJ: Princeton University Press.

Congressional Budget Office. 2020. "The Federal Budget in 2019: An Infographic.” Washington, DC: Congressional Budget Office.

Davis, Angela Y. 2005. Abolition Democracy: Beyond Empire, Prisons, and Torture. New York, NY: Seven Stories Press.

de Tocqueville, Alexis. [1835] 2000. Democracy in America. Translated by Harvey Mansfield. Chicago, IL: University of Chicago Press.

Della Porta, Donatella and Mario Diani. 2006. Social Movements: An 
Introduction. Malden, MA: Blackwell.

DeNardo, James. 1985. Power in Numbers: The Political Strategy of Protest and Rebellion. Princeton, NJ: Princeton University Press.

Dharmapala, Dhammika, Richard McAdams, and John Rappaport. 2020. "Collective Bargaining Rights and Police Misconduct: Evidence from Florida." The Journal of Law, Economics, and Organization 00(1):1-41.

Dorf, Michael C. and Sidney Tarrow. 2014. "Strange Bedfellows: How an Anticipatory Countermovement Brought Same-Sex Marriage into the Public Arena." Law \& Social Inquiry 39(2):449-473.

Du Bois, W.E.B. [1935] 2012. Black Reconstruction in America: Toward A History of The Part Which Black Folk Played in the Attempt to Reconstruct Democracy in America, 1860-1880. Edited by Jones Mack. Abingdon, Oxfordshire: Routledge.

Earl, Jennifer, Andrew Martin, John D. McCarthy, and Sarah Soule. 2004. "The Use of Newspaper Data in the Study of Collective Action." Annual Review of Sociology 30:65-80.

Einstein, Katherine and Vladimir Kogan. 2016. "Pushing the City Limits: Policy Responsiveness in Municipal Government." Urban Affairs Review 52(1):3-32.

Galston, William and Peter Levine. 1998. "America's Civic Condition: A Glance at the Evidence." in Community Works: The Revival of Civil Society in America, edited by E.J. Dionne. Washington, D.C.: Brooking Institute Press.

Gamson, William. 1975. The Strategy of Social Protest. Homewood, IL: Dorsey Press.

Gillion, Daniel. 2020. The Loud Minority: Why Protests Matter in American Democracy. Princeton, NJ: Princeton University Press.

Goodman, Matt. 2020. "The Worst City Council Meeting Dallas Has Witnessed in a Decade." D Magazine. (https://www.dmagazine.com/frontburner/ 2020/06/the-worst-city- 
council-meeting-dallas-has-witnessed-in-a-decade).

Hajnal, Zoltan and Paul Lewis. 2003. "Municipal Institutions and Voter Turnout in Local Elections." Urban Affairs Review 38(5):645-668.

Hart, Joshua. 2021. "Did the COVID-19 pandemic help or hurt Donald Trump's political fortunes?" PLoS ONE 16(2):1-10

Herndon, Astead W. 2020. "How A Pledge to Dismantle the Minneapolis Police Collapsed." The New York Times, September 26. (https://www.nytimes.com/2020/09/26/ us/politics/minneapolis-defundpolice.html).

Hopkins, Daniel J. 2018. The Increasingly United States: How and Why American Political Behaviour Nationalized. Chicago, IL: University of Chicago Press.

Hutter, Swen and Rens Vliegenthart. 2016. "Who Responds to Protest? Protest Politics and Party Responsiveness in Western Europe." Party Politics 24(4):358-369.

Johnson, Eric W. 2008. "Social Movement Size, Organizational Diversity and the Making of Federal Law." Social Forces 86(3):967-993.

Jurjevich, Jason, Phil Keisling, Kevin Rancik, Carson Gorecki, and Stephanie Hawke. 2016. “Who Votes for Mayor?" Portland, Oregon: Urban Studies and Planning Faculty Publications and Presentations. http://archives.pdx.edu/ds/psu/19696.

King, Brayden G., Keith Bentele, and Sarah Soule. 2007. "Protest and Policymaking: Explaining Fluctuation in Congressional Attention to Rights Issues, 1960-1986.” Social Forces 86(1):137-163.

King, Brayden G, Marie Cornwall, and Eric C Dahlin. 2005. "Winning Woman Suffrage One Step at a Time: Social Movements and the Logic of the Legislative Process." Social Forces 83(3):1211-1234.

King, Maya. 2021. "The World is Looking at Us: Minneapolis Puts 'Defund The Police' To A Vote." Politico, September 22.

(https://www.politico.com/news/2021/09/22/minneapolis-reckoning- 
defund-the-police-513568).

Lebron, Christopher J. 2017. The Making of Black Lives Matter: A Brief History of an Idea. New York, NY: Oxford University Press.

Lohmann, Susanne. 1993. "A Signaling Model of Informative and Manipulative Political Action." American Political Science Review 87(2):319-333.

Luders, Joseph. 2006. "The Economics of Movement Success: Business Responses to Civil Rights Mobilization." American Journal of Sociology 111(4):963-998.

Madestam, Andreas, Daniel Shoag, Stan Veuger, and David YanagizawaDrott. 2013. "Do Political Protests Matter? Evidence from the Tea Party Movement." The Quarterly Journal of Economics 128(4):1633-1685.

Martin, Gregory and Joshua McCrain. 2019. Local News and National Politics. Cambridge: Cambridge University Press.

Mazumder, Bhashkar. 2018. "Intergenerational Mobility in The United States: What We Have Learned from the PSID." The Annals of the American Academy of Political and Social Science 680(1):213-234.

McAdam, Doug and Yang Su. 2002. "The War at Home: Antiwar Protests and Congressional Voting, 1965 to 1973.” American Sociological Review 67(5):696-721.

McCarthy, John D. and Mayer Zald. 2002. "The Enduring Vitality of the Resource Mobilization Theory of Social Movements." Pp. 533-565 in Handbook of Sociological Theory, edited by Jonathan H. Turner. Boston, MA: Springer.

McVeigh, Roy, Carl Neblett, and Sarah Shafiq. 2006. "Explaining Social Movement Outcomes: Multiorganizational Fields and Hate Crime Reporting." Mobilization 11(1):23-49.

McVeigh, Roy, Michael Welch, and Thoroddur Bjaranason. 2003. "Hate Crime Reporting as a Successful Social Movement Outcome." American Sociological Review 68(6):843-867. 
Mellon, Jon. Forthcoming. "Rain, Rain, Go Away: 176 Potential ExclusionRestriction Violations for Studies Using Weather as an Instrumental Variable."SSRN.https://papers.ssrn.com/sol3/papers.cfm?abstract_id=3 715610\#references-widget

Meyer, David. 2004. "Protest and Political opportunities." Annual Review of Sociology 30(1):125-145.

Meyer, David and Debra Minkoff. 2004. "Conceptualizing Political Opportunity." Social Forces 82(4):1457-1492.

2021. "Legislative Responses for Policing-State Bill Tracking Database." Washington, D.C.: National Conference of State Legislatures.

(https://www.ncsl.org/research/civil-and-criminal-justice/legislativeresponses-for-policing)

Oliver, Eric and Shang E. Ha. 2007. "Vote Choice in Suburban Elections." American Political Science Review 101(3):393-408.

Oliver, Eric, Shang Ha, and Zachary Callen. 2012. Local Elections and the Politics of Small-Scale Democracy. Princeton, NJ: Princeton University Press.

Oliver, Pamela. 2020. "Resisting Repression: The Black Lives Matter Movement in Context." In Racialized Protest and the State: Resistance and Repression in a Divided America, edited by Hank Johnston and Pamela Oliver. Abingdon, Oxfordshire: Routledge.

Olzak, Susan and Sarah Soule. 2009. "Cross-Cutting Influences of Environmental Protest and Legislation." Social Forces 88(1): 201-225. Parker, Kim and Kiley Hurst. 2021. "Growing Share of Americans Say They Want More Spending on Police in Their Area." PewResearch, October 26. https://www.pewresearch.org/fact-tank/2021/10/26/growing-shareof-americans-say-they-want-more-spending-on-police-in-their-area/

Peterson, Paul E. 1981. City Limits. Chicago, IL: University of Chicago Press. Piven, Frances Fox and Richard Cloward. 1979. Poor People's Movements: Why They Succeed, How They Fail. New York, NY: Penguin Random House. 
Pressman, Jeremy and Austin Choi-Fitzpatrick. 2020. "Covid-19 and Protest Repertoires in the United States: An Initial Description of Limited Change." Social Movement Studies 19:1-8.

Putnam, Robert D. 2000. Bowling Alone: The Collapse and Revival of American Community. New York, NY: Simon \& Schuster.

Rakich, Nathaniel. 2020. "How Americans feel about 'Defunding the Police." FiveThirtyEight, June 19.

(https://fivethirtyeight.com/features/americans-like-the-ideas-behinddefunding-the-police-more-than-the-slogan-itself/)

Ransby, Barbara. 2018. Making All Black Lives Matter: Reimagining Freedom in the Twenty-First Century. Los Angeles, CA: University of California Press.

Schaffner, Brian, Jesse Rhodes, and Ray La Raja. 2020. Hometown Inequality: Race, Class, and Representation in American Local Politics. New York, NY: Cambridge University Press.

Scheiber, Noam, Farah Stockman, and David Goodman. 2020. "How Police Unions Became Such Powerful Opponents to Reform Efforts." The New York Times, June 7.

(https://www.nytimes.com/2020/06/06/us/police-unions-minneapoliskroll.html)

Smith, Dakota and Richard Winton. 2021. "L.A. Cracks Down on 'Out of Control' Protests. Some Call It Overreach." LATimes, September 21. (https://www.latimes.com/california/story/2021-09-21/l-a-cracks-downon-out-of-control-protests-some-call-it-overreach)

Smith, Jackie, John D. McCarthy, Clark McPhail, and Boguslaw Augustyn. 2001. "From Protest to Agenda Building: Description Bias in Media Coverage of Protest Events in Washington, D.C." Social Forces 79(4):1397-1423.

Sobolev, Anton, Keith Chen, Jungseock Joo, and Zachary Steinert-Threlkeld. 2020. "News and Geolocated Social Media Accurately Measure Protest 
Size Variation.” American Political Science Review 114(4):1343-1351.

Soule, Sarah and Susan Olzak. 2004. "When Do Movements Matter? The

Politics of Contingency and the Equal Rights Amendment." American Sociological Review 69(4):473-497.

Tausanovitch, Chris and Christopher Warshaw. 2014. "Representation in Municipal Government." American Political Science Review 108(3):605641.

Teeselink, Bouke Klein and Georgios Melios. Forthcoming. "Weather to

Protest: The Effect of Black Lives Matter Protests on the 2020 Presidential Election." SSRN.

(https://papers.ssrn.com/sol3/papers.cfm?abstract_id=3809877)

Tilly, Charles. 2006. "WUNC.” Pp. 289-306 in Crowds, edited by J.T.

Schnapp and M. Tiews. Stanford, CA: Stanford University Press.

Tilly, Charles. 2008. Social Movements, 1768-2004. Boulder, CO: Paradigm.

Timoneda, Joan C. and Erik Wibbels. 2021. "Spikes and Variance: Using Google Trends to Detect and Forecast Protests." Political Analysis:1-18.

Trounstine, Jessica. 2009. "All Politics is Local: The Reemergence of the Study of City Politics." Perspectives on Politics 2(3):611-618.

U.S. Bureau of the Census. 2021. Annual State and Local Government Finances Summary: 2019. Washington, DC: U.S. Department of Commerce.

Valentine, Randall, Dawn Valentine and Jimmie Valentine. 2020. "Relationship of George Floyd Protests to Increases in Covid-19 Cases Using Event Study Methodology." Journal of Public Health (Oxf) 42:696-697.

Vitale, Alex S. 2017. The End of Policing. New York, NY: Verso Books.

Vliegenthart, Rens, Stefaan Walgrave, Ruud Wouters, Swen Hutter, Will Jennings, Roy Gava, Anke Tresch, Frédéric Varone, Emiliano 
Grossman, Christian Breunig, Sylvain Brouard, and Laura ChaquesBonafont. 2016. "The Media as a Dual Mediator of the Political AgendaSetting Effect of Protest. A Longitudinal Study in Six Western European Countries." Social Forces 95(2):837-859.

Walgrave, Stefaan, Stuart Soroka, and Michael Nuytemans. 2008. "The Mass Media's Political Agenda-Setting Power: A Longitudinal Analysis of Media, Parliament, And Government in Belgium (1993 to 2000).” Comparative Political Studies 41(6):814-836.

Walgrave, Stefaan and Rens Vliegenthart. 2012. "The Complex AgendaSetting Power of Protest: Demonstrations, Media, Parliament, Government and Legislation in Belgium, 1993-2000." Mobilization 17(2):129-156.

Warshaw, Christopher. 2019. "Local Elections and Representation in The United States." Annual Review of Political Science 22:461-479.

Wasow, Omar. 2020. "Agenda Seeding: How 1960s Black Protest Moved Elites, Public Opinion and Voting." American Political Science Review 114(3):638-659.

Wong, Peter. 2021. "Oregon Passed More Than a Dozen Police Reform Bills." Democrat Herald, July 2.

(https://democratherald.com/news/local/oregon-passed-more-than-adozen-police-reform-bills/article_4bf1cd5b-1072-5940-9c96086ab3a2eb39.html)

Wouters, Ruud and Stefaan Walgrave. 2017. "Demonstrating Power: How Protest Persuades Political Representatives." American Sociological Review 82(2):361-383. 


\section{A.Descriptive Statistics for Protest Variables}

Descriptive statistics for city-level protest variables are displayed in Table

A.1, while those for state-level variables are shown in A.2.

\begin{tabular}{|c|c|c|c|c|c|c|c|}
\hline Statistic & $\mathrm{N}$ & Mean & St. Dev. & Min & $\operatorname{Pctl}(25)$ & $\operatorname{Pctl}(75)$ & Max \\
\hline City-level protesters per month per 100,000 population & 222 & 961.20 & $1,854.63$ & 0.00 & 83.33 & 775.40 & $12,391.85$ \\
\hline City-level protest events per month per 100,000 population & 222 & 2.52 & 2.75 & 0.05 & 0.72 & 3.36 & 17.43 \\
\hline Total national protesters in month before budget approval & 227 & $1,023.69$ & $1,051.46$ & 10.64 & 55.60 & $2,297.14$ & $2,420.60$ \\
\hline City-level number of arrests per month per 100,000 population & 222 & 5.72 & 20.71 & 0.00 & 0.00 & 1.87 & 145.48 \\
\hline City-level number of participant injuries per month per 100,000 population & 222 & 0.12 & 0.53 & 0.00 & 0.00 & 0.00 & 5.81 \\
\hline City-level number of police injuries per month per 100,000 population & 222 & 0.30 & 2.39 & 0.00 & 0.00 & 0.00 & 34.86 \\
\hline City-level instances of property damage per month per 100,000 population & 222 & 0.26 & 0.75 & 0.00 & 0.00 & 0.22 & 9.05 \\
\hline Binary violent protest measure & 222 & 0.45 & 0.50 & 0.00 & 0.00 & 1.00 & 1.00 \\
\hline
\end{tabular}

Table A.1: Descriptive statistics for city-level protest variables

\begin{tabular}{|c|c|c|c|c|c|c|c|}
\hline Statistic & $\mathrm{N}$ & Mean & St. Dev. & Min & $\operatorname{Pctl}(25)$ & $\operatorname{Pctl}(75)$ & Max \\
\hline State-level protesters per month per 100,000 urban population & 51 & $1,175.83$ & $1,253.57$ & 238.45 & 504.69 & $1,301.65$ & $7,768.04$ \\
\hline State-level protest events per month per 100,000 urban population & 51 & 3.46 & 3.43 & 0.11 & 2.04 & 3.81 & 23.48 \\
\hline State-level number of participant injuries per month per 100,000 urban population & 51 & 0.15 & 0.21 & 0.00 & 0.02 & 0.21 & 1.30 \\
\hline State-level number of police injuries per month per 100,000 urban population & 51 & 0.19 & 0.37 & 0 & 0 & 0.2 & 2 \\
\hline State-level instances of property damage per month per 100,000 urban population & 51 & 0.20 & 0.28 & 0 & 0.1 & 0.3 & 2 \\
\hline
\end{tabular}

Table A.2: Descriptive statistics for state-level protest variables

\section{B. Correlation Matrices}

Figures B.1 and B.2 indicate that cities where defunding occurred saw larger, more numerous, and more disruptive protests across the period from May 26th onwards. These cities were also larger than average, with a large foreign-born population, a larger black community, smaller average household size (often a proxy for urbanization), a smaller share of veteran population, and experienced reductions in the city budget more generally. Covid-19 cases and deaths were higher in cities which saw significant defunding, even controlling for their larger population size. Democratic vote shares in the 2020 Presidential election were also higher in these cities. Many of these characteristics are linked to defunding but are also associated with increases in police spending. Populous cities with a large immigrant population and low white population shares are far more likely to either decrease or increase their police budgets. 
States with higher levels of police reform had larger and more numerous protests, with a higher degree of violence, measured in terms of property damage and injuries to police and participants, as shown in Figures B.3 and B.4. States with more police reform related legislative activity were also larger, with a larger Democratic vote share in the 2020 Presidential election and a greater college graduate population share. States with a lot of reform activity had a larger foreign-born population, with smaller white and Asian population shares and higher black population shares. No clear trend appears to relate Covid-19 cases or deaths per million population to police reform legislative activity. These demographic variables plausibly relate to both the scale of BLM protests as well as the level of police reform legislative activity, and so they must be included in any subsequent regression analysis.

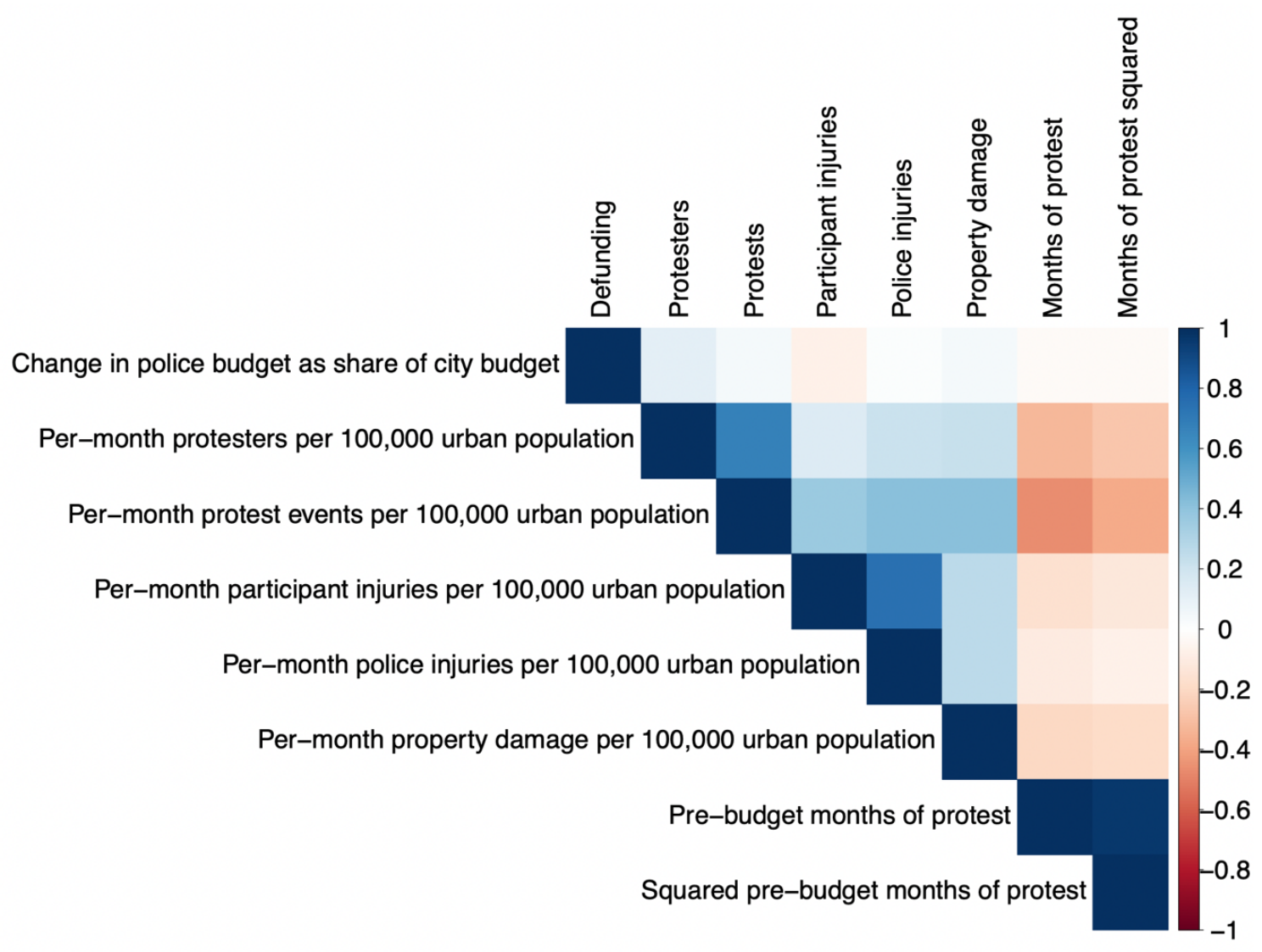

Figure B.1: Correlation matrix for city-level control variables 


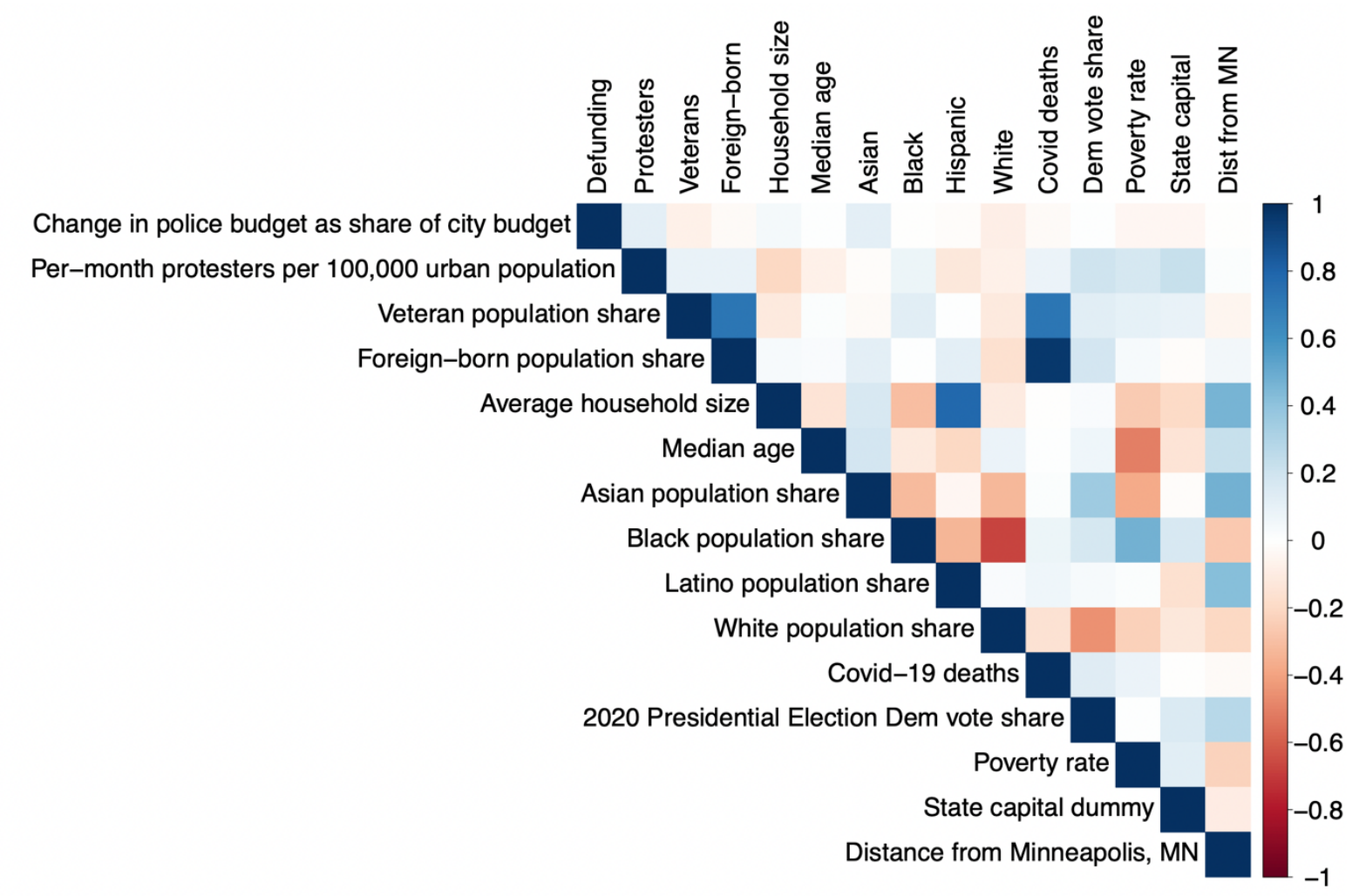

Figure B.2: Correlation matrix for city-level protest variables

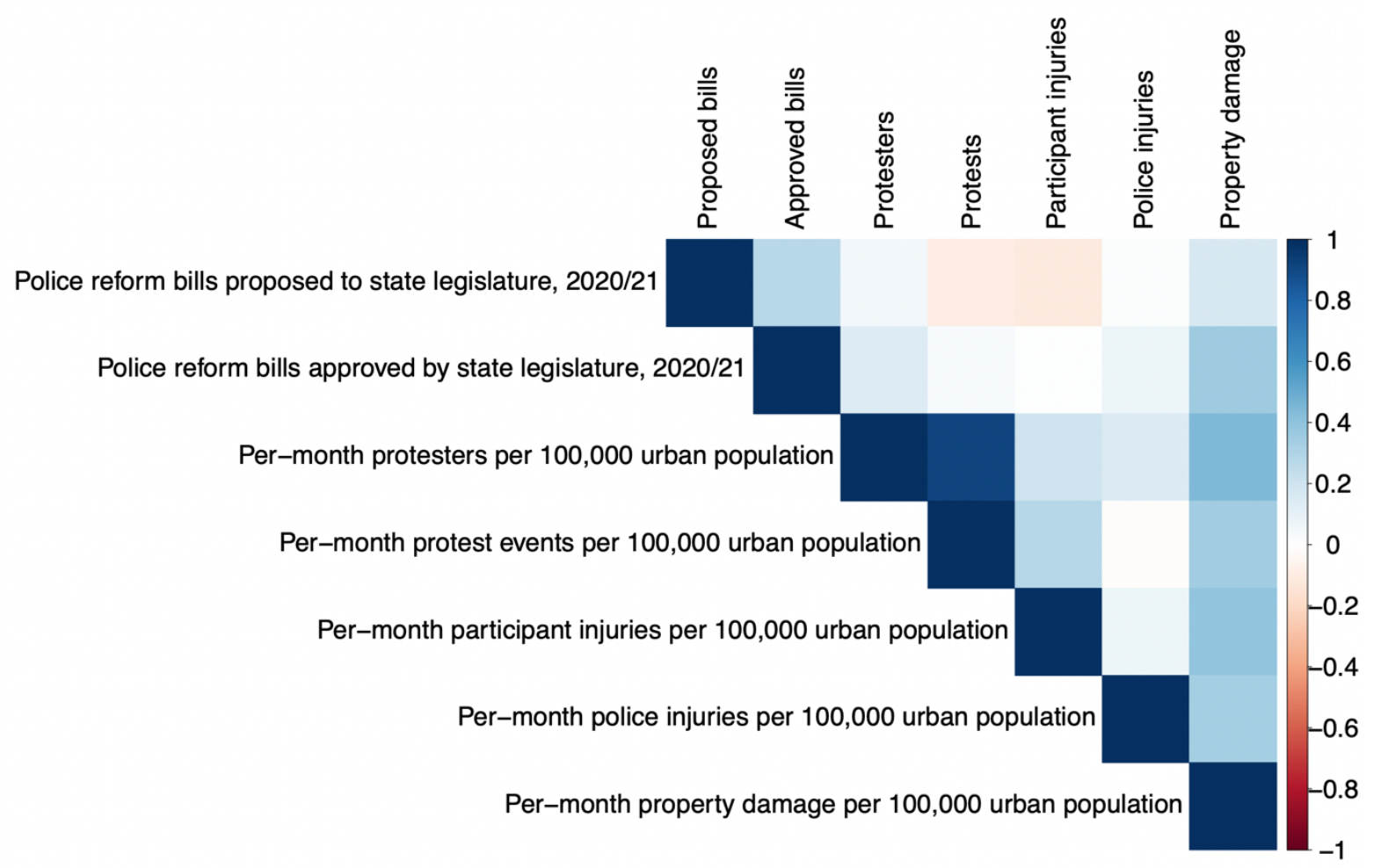

Figure B.3: Correlation matrix for state-level protest variables 


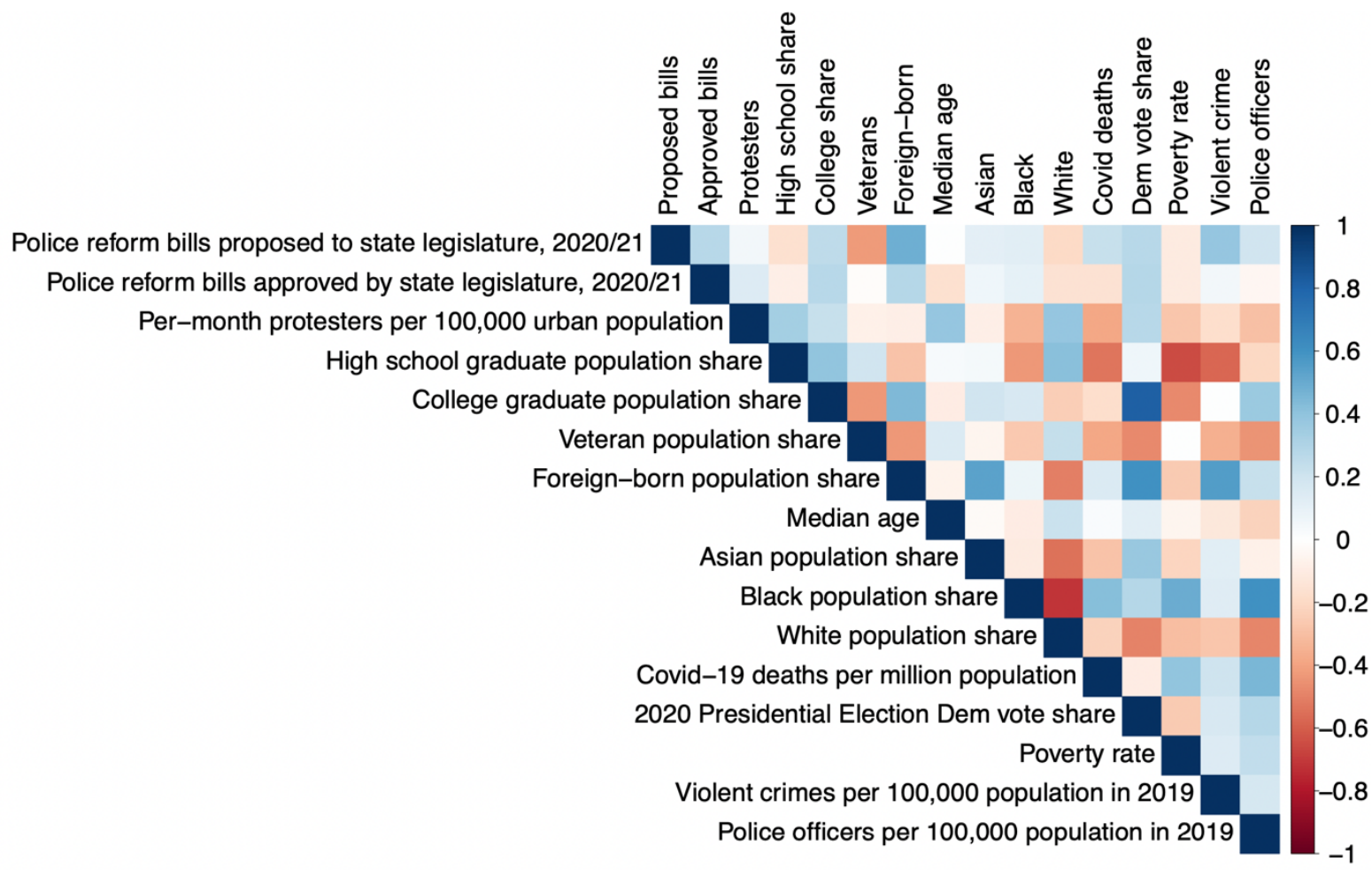

Figure B.4: Correlation matrix for state-level control variables

\section{Data Collection Process}

No central database for city budgets exists. Therefore, manual collection from city websites was necessary. For our data collection, three research assistants were instructed to manually compile spending data for the 300 largest cities in America. Research assistants were provided with a standardized spreadsheet with drop-down fields to enter data. The following variables were collected: the adopted police budget 2018-2019, adopted police personnel 2018-2019, adopted police budget 2019-2020, adopted police personnel 2019-2020, proposed police budget 2020-2021, adopted police budget 2020-2021, adopted police personnel 2020-2021, adopted total city budget 2018-2019, adopted total city budget 2019-2020, pro- posed city budget 2020-2021, adopted total city budget 20202021, all weblinks used to retrieve budget data, and any additional comments or questions for each city. Following the initial budget collection, each city underwent a second review by one of the authors to correct any remaining collection errors. 
City budgets are usually divided into the general fund and other external sources of funding. The general fund is the largest funding source and at the discretion of the municipal government. For external funding sources, cities often receive non-discretionary state and local grants. A big portion of police budgets is held within the capital budget, which generally pertains to infrastructure or long-term spending projects. While capital budgets are often listed as combined with general funds, in cases where they were listed separately, we summed them together. For reporting police personnel, we include full time employees in addition to part time employees.

Each city is responsible for its own budget reporting. Therefore, the level of transparency and specificity of budgets varies between cities. Irregularity in budget reporting resulted in several limitations to our city budget data. Of the 300 cities in our list, 16 cities did not report their 2021 adopted budgets, and an additional 21 cities did not report personnel numbers for police departments. Cities also varied in their reporting of general fund or total city expenditures. When available, we reported the city's total expenditures for the overall city budget. When total city expenditures were unavailable, we listed the city's general fund.

\section{City-level protest and Changes in Registered Personnel}

\begin{tabular}{|c|c|c|c|c|c|c|c|}
\hline & \multicolumn{7}{|c|}{ Change in personnel registered on police budget, 2019/20 - 2020/21 } \\
\hline & (1) & $(2)$ & (3) & (4) & (5) & (6) & (7) \\
\hline Protesters per month per 100,000 population & -0.004 & -0.002 & -0.001 & 0.001 & 0.001 & -0.001 & 0.001 \\
\hline Constant & 3.326 & -154.495 & $-367.471^{+}$ & -319.515 & -305.127 & -233.535 & -254.010 \\
\hline Demographic controls & $\mathrm{N}$ & $\mathrm{Y}$ & $\mathrm{Y}$ & $\mathrm{Y}$ & $\mathrm{Y}$ & Y & $\mathrm{Y}$ \\
\hline Race controls & $\mathrm{N}$ & $\mathrm{N}$ & $\mathrm{Y}$ & $\mathrm{Y}$ & $\mathrm{Y}$ & $\mathrm{Y}$ & $\mathrm{Y}$ \\
\hline Poverty, Covid-19, and Dem vote share & $\mathrm{N}$ & $\mathrm{N}$ & $\mathrm{N}$ & $\mathrm{Y}$ & $\mathrm{Y}$ & $\mathrm{Y}$ & $\mathrm{Y}$ \\
\hline Protest violence controls & $\mathrm{N}$ & $\mathrm{N}$ & $\mathrm{N}$ & $\mathrm{N}$ & $\mathrm{Y}$ & $\mathrm{Y}$ & $\mathrm{Y}$ \\
\hline State capital and dist. to Minneapolis & $\mathrm{N}$ & $\mathrm{N}$ & $\mathrm{N}$ & $\mathrm{N}$ & $\mathrm{N}$ & $\mathrm{Y}$ & $\mathrm{Y}$ \\
\hline Time and time ${ }^{2}$ controls & $\mathrm{N}$ & $\mathrm{N}$ & $\mathrm{N}$ & $\mathrm{N}$ & $\mathrm{N}$ & $\mathrm{N}$ & $\mathrm{Y}$ \\
\hline$N$ & 199 & 199 & 199 & 193 & 193 & 193 & 193 \\
\hline $\mathrm{R}^{2}$ & 0.003 & 0.138 & 0.157 & 0.172 & 0.178 & 0.195 & 0.204 \\
\hline Adjusted $\mathrm{R}^{2}$ & -0.002 & 0.116 & 0.117 & 0.116 & 0.103 & 0.112 & 0.111 \\
\hline
\end{tabular}

Table D.1: City-level number of protesters and change in personnel, with and without 
controls

\section{E. Protest Measurement: Modelling Using Number of Protest Events Instead of Number of Protesters}

\begin{tabular}{lccccccc}
\hline & \multicolumn{7}{c}{ Change in police budget as a share of city budget, 2019/20 - 2020/21 } \\
& $(1)$ & $(2)$ & $(3)$ & $(4)$ & $(5)$ & $(6)$ & $(7)$ \\
\hline Protest events per month per 100,000 population & 0.032 & 0.039 & 0.025 & 0.042 & 0.038 & 0.065 & 0.069 \\
Constant & -0.013 & -0.806 & 0.963 & 2.402 & 2.285 & 1.702 & 1.625 \\
Demographic controls & $\mathrm{N}$ & $\mathrm{Y}$ & $\mathrm{Y}$ & $\mathrm{Y}$ & $\mathrm{Y}$ & $\mathrm{Y}$ & $\mathrm{Y}$ \\
Race controls & $\mathrm{N}$ & $\mathrm{N}$ & $\mathrm{Y}$ & $\mathrm{Y}$ & $\mathrm{Y}$ & $\mathrm{Y}$ & $\mathrm{Y}$ \\
Poverty, Covid-19, and Dem vote share & $\mathrm{N}$ & $\mathrm{N}$ & $\mathrm{N}$ & $\mathrm{Y}$ & $\mathrm{Y}$ & $\mathrm{Y}$ & $\mathrm{Y}$ \\
Protest violence controls & $\mathrm{N}$ & $\mathrm{N}$ & $\mathrm{N}$ & $\mathrm{N}$ & $\mathrm{Y}$ & $\mathrm{Y}$ & $\mathrm{Y}$ \\
State capital and dist. to Minneapolis & $\mathrm{N}$ & $\mathrm{N}$ & $\mathrm{N}$ & $\mathrm{N}$ & $\mathrm{N}$ & $\mathrm{Y}$ & $\mathrm{Y}$ \\
Time and time controls & $\mathrm{N}$ & $\mathrm{N}$ & $\mathrm{N}$ & $\mathrm{N}$ & $\mathrm{N}$ & $\mathrm{N}$ & $\mathrm{Y}$ \\
$N$ & 217 & 217 & 217 & 211 & 211 & 211 & 211 \\
$\mathrm{R}^{2}$ & 0.002 & 0.011 & 0.025 & 0.030 & 0.047 & 0.059 & 0.060 \\
Adjusted $^{2}$ & -0.003 & -0.012 & -0.017 & -0.028 & -0.032 & -0.029 & -0.039 \\
\hline
\end{tabular}

${ }^{+} \mathrm{p}<0.1 ;{ }^{*} \mathrm{p}<0.05 ;{ }^{* *} \mathrm{p}<0.01 ;{ }^{* * *} \mathrm{p}<0.001$

Table E.1: City-level number of protests and defunding, with and without controls

\begin{tabular}{|c|c|c|c|c|c|c|c|}
\hline & \multicolumn{7}{|c|}{ State-level number of approved police reform bills, $2020 / 21$} \\
\hline & (1) & $(2)$ & (3) & (4) & (5) & (6) & (7) \\
\hline Protest events per month per 100,000 urban population & 0.011 & $0.081^{* *}$ & $0.096^{* *}$ & $0.071^{+}$ & $0.082^{*}$ & $0.065^{+}$ & $0.077^{+}$ \\
\hline Constant & $1.142^{* * *}$ & $12.323^{*}$ & 6.109 & 5.992 & 4.526 & $19.264^{+}$ & 4.422 \\
\hline Demographic controls & $\mathrm{N}$ & $\mathrm{Y}$ & $\mathrm{Y}$ & $\mathrm{Y}$ & $\mathrm{Y}$ & $\mathrm{Y}$ & $\mathrm{Y}$ \\
\hline Race controls & $\mathrm{N}$ & $\mathrm{N}$ & $\mathrm{Y}$ & $\mathrm{Y}$ & $\mathrm{Y}$ & $\mathrm{Y}$ & $\mathrm{Y}$ \\
\hline Poverty, Covid-19, and Dem vote share & $\mathrm{N}$ & $\mathrm{N}$ & $\mathrm{N}$ & $\mathrm{Y}$ & $\mathrm{Y}$ & $\mathrm{Y}$ & $\mathrm{Y}$ \\
\hline Protest violence controls & $\mathrm{N}$ & $\mathrm{N}$ & $\mathrm{N}$ & $\mathrm{N}$ & $\mathrm{Y}$ & $\mathrm{Y}$ & $\mathrm{Y}$ \\
\hline Violent crime, 2019 & $\mathrm{~N}$ & $\mathrm{~N}$ & $\mathrm{~N}$ & $\mathrm{~N}$ & $\mathrm{~N}$ & $\mathrm{Y}$ & $\mathrm{N}$ \\
\hline Police officers, 2019 & $\mathrm{~N}$ & $\mathrm{~N}$ & $\mathrm{~N}$ & $\mathrm{~N}$ & $\mathrm{~N}$ & $\mathrm{~N}$ & $\mathrm{Y}$ \\
\hline$N$ & 51 & 51 & 51 & 51 & 51 & 51 & 51 \\
\hline Log Likelihood & -154.756 & -130.919 & -126.913 & -125.402 & -119.479 & -114.089 & -117.280 \\
\hline AIC & 313.511 & 275.839 & 273.827 & 276.804 & 270.958 & 262.178 & 268.561 \\
\hline
\end{tabular}

Table E.2: State-level number of protests and approved police reform bills, with and without controls

State-level number of proposed police reform bills, 2020/21

\begin{tabular}{|c|c|c|c|c|c|c|c|}
\hline & $(1)$ & $(2)$ & (3) & (4) & $(5)$ & $(6)$ & (7) \\
\hline Protest events per month per 100,000 urban population & -0.041 & -0.006 & 0.023 & 0.032 & 0.018 & 0.038 & 0.005 \\
\hline Constant & $3.365^{* * *}$ & 2.882 & -3.861 & -0.423 & -1.954 & -10.528 & -1.922 \\
\hline Demographic controls & $\mathrm{N}$ & $\mathrm{Y}$ & $\mathrm{Y}$ & $\mathrm{Y}$ & Y & $\mathrm{Y}$ & $\mathrm{Y}$ \\
\hline Race controls & $\mathrm{N}$ & $\mathrm{N}$ & $\mathrm{Y}$ & $\mathrm{Y}$ & $\mathrm{Y}$ & $\mathrm{Y}$ & $\mathrm{Y}$ \\
\hline Poverty, Covid-19, and Dem vote share & $\mathrm{N}$ & $\mathrm{N}$ & $\mathrm{N}$ & $\mathrm{Y}$ & $\mathrm{Y}$ & $\mathrm{Y}$ & $\mathrm{Y}$ \\
\hline Protest violence controls & $\mathrm{N}$ & $\mathrm{N}$ & $\mathrm{N}$ & $\mathrm{N}$ & $\mathrm{Y}$ & $\mathrm{Y}$ & $\mathrm{Y}$ \\
\hline Violent crime, 2019 & $\mathrm{~N}$ & $\mathrm{~N}$ & $\mathrm{~N}$ & $\mathrm{~N}$ & $\mathrm{~N}$ & $\mathrm{Y}$ & $\mathrm{N}$ \\
\hline Police officers, 2019 & $\mathrm{~N}$ & $\mathrm{~N}$ & $\mathrm{~N}$ & $\mathrm{~N}$ & $\mathrm{~N}$ & $\mathrm{~N}$ & $\mathrm{Y}$ \\
\hline$N$ & 51 & 51 & 51 & 51 & 51 & 51 & 51 \\
\hline Log Likelihood & -677.751 & -478.731 & -444.020 & -441.489 & -368.871 & -355.674 & -356.344 \\
\hline AIC & $1,359.502$ & 971.462 & 908.040 & 908.977 & 769.742 & 745.348 & 746.688 \\
\hline
\end{tabular}

${ }^{+} \mathrm{p}<0.1 ;{ }^{*} \mathrm{p}<0.05 ;{ }^{* *} \mathrm{p}<0.01 ;{ }^{* * *} \mathrm{p}<0.001$ 
Table E.3: State-level number of protests and proposed police reform bills, with and without controls

\section{F. State-level Modelling with D.C. Excluded}

\begin{tabular}{|c|c|c|c|c|c|c|c|}
\hline & \multicolumn{7}{|c|}{ State-level number of approved police reform bills, 2020/21 } \\
\hline & (1) & $(2)$ & (3) & (4) & (5) & (6) & (7) \\
\hline Protesters per month per 100,000 urban population & 0.0001 & $0.0003^{* *}$ & $0.0003^{* *}$ & $0.0002^{+}$ & $0.0002^{+}$ & 0.0001 & $0.0002^{+}$ \\
\hline Constant & $1.025^{* * *}$ & $17.070^{* *}$ & 9.314 & 5.655 & 3.912 & $19.394^{+}$ & 4.898 \\
\hline Demographic controls & $\mathrm{N}$ & $\mathrm{Y}$ & $\mathrm{Y}$ & $\mathrm{Y}$ & $\mathrm{Y}$ & $\mathrm{Y}$ & $\mathrm{Y}$ \\
\hline Race controls & $\mathrm{N}$ & $\mathrm{N}$ & $\mathrm{Y}$ & $\mathrm{Y}$ & $\mathrm{Y}$ & $\mathrm{Y}$ & $\mathrm{Y}$ \\
\hline Poverty, Covid-19, and Dem vote share & $\mathrm{N}$ & $\mathrm{N}$ & $\mathrm{N}$ & $\mathrm{Y}$ & $\mathrm{Y}$ & $\mathrm{Y}$ & $\mathrm{Y}$ \\
\hline Protest violence controls & $\mathrm{N}$ & $\mathrm{N}$ & $\mathrm{N}$ & $\mathrm{N}$ & $\mathrm{Y}$ & $\mathrm{Y}$ & $\mathrm{Y}$ \\
\hline Violent crime, 2019 & $\mathrm{~N}$ & $\mathrm{~N}$ & $\mathrm{~N}$ & $\mathrm{~N}$ & $\mathrm{~N}$ & $\mathrm{Y}$ & $\mathrm{N}$ \\
\hline Police officers, 2019 & $\mathrm{~N}$ & $\mathrm{~N}$ & $\mathrm{~N}$ & $\mathrm{~N}$ & $\mathrm{~N}$ & $\mathrm{~N}$ & $\mathrm{Y}$ \\
\hline$N$ & 50 & 50 & 50 & 50 & 50 & 50 & 50 \\
\hline Log Likelihood & -150.590 & -123.470 & -120.450 & -119.219 & -115.047 & -109.125 & -114.678 \\
\hline AIC & 305.180 & 260.939 & 260.900 & 264.438 & 262.093 & 252.249 & 263.357 \\
\hline
\end{tabular}

Table F.1: State-level number of protesters and approved police reform bills, with D.C. excluded

\begin{tabular}{|c|c|c|c|c|c|c|c|}
\hline & \multicolumn{7}{|c|}{ State-level number of proposed police reform bills, $2020 / 21$} \\
\hline & (1) & (2) & (3) & (4) & (5) & $(6)$ & (7) \\
\hline Protesters per month per 100,000 urban population & 0.00004 & 0.00002 & 0.0001 & 0.0001 & 0.00005 & 0.0001 & 0.0001 \\
\hline Constant & $3.191^{* * *}$ & 7.584 & -1.662 & -1.786 & -3.826 & -12.253 & -3.301 \\
\hline Demographic controls & $\mathrm{N}$ & $\mathrm{Y}$ & $\mathrm{Y}$ & $\mathrm{Y}$ & $\mathrm{Y}$ & $\mathrm{Y}$ & $\mathrm{Y}$ \\
\hline Race controls & $\mathrm{N}$ & $\mathrm{N}$ & $\mathrm{Y}$ & $\mathrm{Y}$ & $\mathrm{Y}$ & $\mathrm{Y}$ & $\mathrm{Y}$ \\
\hline Poverty, Covid-19, and Dem vote share & $\mathrm{N}$ & $\mathrm{N}$ & $\mathrm{N}$ & $\mathrm{Y}$ & $\mathrm{Y}$ & $\mathrm{Y}$ & $\mathrm{Y}$ \\
\hline Protest violence controls & $\mathrm{N}$ & $\mathrm{N}$ & $\mathrm{N}$ & $\mathrm{N}$ & $\mathrm{Y}$ & $\mathrm{Y}$ & $\mathrm{Y}$ \\
\hline Violent crime, 2019 & $\mathrm{~N}$ & $\mathrm{~N}$ & $\mathrm{~N}$ & $\mathrm{~N}$ & $\mathrm{~N}$ & $\mathrm{Y}$ & $\mathrm{N}$ \\
\hline Police officers, 2019 & $\mathrm{~N}$ & $\mathrm{~N}$ & $\mathrm{~N}$ & $\mathrm{~N}$ & $\mathrm{~N}$ & $\mathrm{~N}$ & $\mathrm{Y}$ \\
\hline$N$ & 50 & 50 & 50 & 50 & 50 & 50 & 50 \\
\hline Log Likelihood & -678.136 & -449.292 & -408.584 & -408.130 & -345.415 & -332.711 & -344.533 \\
\hline AIC & $1,360.273$ & 912.584 & 837.168 & 842.260 & 722.830 & 699.422 & 723.067 \\
\hline
\end{tabular}

Table F.2: State-level number of protesters and proposed police reform bills, with D.C. excluded 


\section{G. Modelling with a Quadratic Term on Protest}

\begin{tabular}{|c|c|c|c|c|c|c|c|}
\hline & \multicolumn{7}{|c|}{ Change in police budget as a share of city budget, $2019 / 20-2020 / 21$} \\
\hline & (1) & (2) & (3) & (4) & $(5)$ & (6) & (7) \\
\hline Protesters per month per 100,000 population & -0.0001 & -0.0001 & -0.0001 & -0.00005 & -0.0001 & -0.00004 & -0.00004 \\
\hline Per-month protesters per capita squared & 0.00000 & 0.00000 & 0.00000 & 0.00000 & 0.00000 & 0.00000 & 0.00000 \\
\hline Constant & 0.049 & -0.844 & 0.308 & 1.859 & 1.811 & 1.465 & 1.483 \\
\hline Demographic controls & $\mathrm{N}$ & $\mathrm{Y}$ & $\mathrm{Y}$ & $\mathrm{Y}$ & Y & Y & Y \\
\hline Race controls & $\mathrm{N}$ & $\mathrm{N}$ & $\mathrm{Y}$ & $\mathrm{Y}$ & $\mathrm{Y}$ & $\mathrm{Y}$ & $\mathrm{Y}$ \\
\hline Poverty, Covid-19, and Dem vote share & $\mathrm{N}$ & $\mathrm{N}$ & $\mathrm{N}$ & $\mathrm{Y}$ & $\mathrm{Y}$ & $\mathrm{Y}$ & $\mathrm{Y}$ \\
\hline Protest violence controls & $\mathrm{N}$ & $\mathrm{N}$ & $\mathrm{N}$ & $\mathrm{N}$ & $\mathrm{Y}$ & $\mathrm{Y}$ & $\mathrm{Y}$ \\
\hline State capital and dist. to Minneapolis & $\mathrm{N}$ & $\mathrm{N}$ & $\mathrm{N}$ & $\mathrm{N}$ & $\mathrm{N}$ & $\mathrm{Y}$ & $\mathrm{Y}$ \\
\hline Time and time ${ }^{2}$ controls & $\mathrm{N}$ & $\mathrm{N}$ & $\mathrm{N}$ & $\mathrm{N}$ & $\mathrm{N}$ & $\mathrm{N}$ & $\mathrm{Y}$ \\
\hline$N$ & 217 & 217 & 217 & 211 & 211 & 211 & 211 \\
\hline $\mathrm{R}^{2}$ & 0.020 & 0.030 & 0.045 & 0.054 & 0.068 & 0.082 & 0.082 \\
\hline Adjusted $\mathrm{R}^{2}$ & 0.010 & 0.003 & -0.001 & -0.008 & -0.014 & -0.009 & -0.019 \\
\hline
\end{tabular}

Table G.1: City-level number of protesters and defunding, with a quadratic term for protest

\section{H. Modelling with Logged Protest}

\begin{tabular}{|c|c|c|c|c|c|c|c|}
\hline & \multicolumn{7}{|c|}{ Change in police budget as a share of city budget, $2019 / 20-2020 / 21$} \\
\hline & $(1)$ & $(2)$ & (3) & (4) & $(5)$ & $(6)$ & (7) \\
\hline Logged protesters per month per 100,000 population & 0.045 & 0.061 & 0.027 & 0.074 & 0.066 & 0.092 & 0.073 \\
\hline Constant & -0.216 & -0.169 & 1.646 & 4.103 & 3.907 & 3.669 & 3.979 \\
\hline Demographic controls & $\mathrm{N}$ & $\mathrm{Y}$ & $\mathrm{Y}$ & $\mathrm{Y}$ & $\mathrm{Y}$ & $\mathrm{Y}$ & $\mathrm{Y}$ \\
\hline Race controls & $\mathrm{N}$ & $\mathrm{N}$ & $\mathrm{Y}$ & $\mathrm{Y}$ & $\mathrm{Y}$ & $\mathrm{Y}$ & $\mathrm{Y}$ \\
\hline Poverty, Covid-19, and Dem vote share & $\mathrm{N}$ & $\mathrm{N}$ & $\mathrm{N}$ & $\mathrm{Y}$ & $\mathrm{Y}$ & $\mathrm{Y}$ & $\mathrm{Y}$ \\
\hline Protest violence controls & $\mathrm{N}$ & $\mathrm{N}$ & $\mathrm{N}$ & $\mathrm{N}$ & $\mathrm{Y}$ & $\mathrm{Y}$ & $\mathrm{Y}$ \\
\hline State capital and dist. to Minneapolis & $\mathrm{N}$ & $\mathrm{N}$ & $\mathrm{N}$ & $\mathrm{N}$ & $\mathrm{N}$ & $\mathrm{Y}$ & $\mathrm{Y}$ \\
\hline Time and time ${ }^{2}$ controls & $\mathrm{N}$ & $\mathrm{N}$ & $\mathrm{N}$ & $\mathrm{N}$ & $\mathrm{N}$ & $\mathrm{N}$ & $\mathrm{Y}$ \\
\hline$N$ & 206 & 206 & 206 & 200 & 200 & 200 & 200 \\
\hline $\mathrm{R}^{2}$ & 0.001 & 0.008 & 0.020 & 0.030 & 0.049 & 0.058 & 0.058 \\
\hline Adjusted $\mathrm{R}^{2}$ & -0.004 & -0.017 & -0.025 & -0.032 & -0.034 & -0.036 & -0.047 \\
\hline
\end{tabular}

${ }^{+} \mathrm{p}<0.1 ;{ }^{*} \mathrm{p}<0.05 ;{ }^{* *} \mathrm{p}<0.01 ;{ }^{* * *} \mathrm{p}<0.001$

Table H.1: City-level number of protesters and defunding, with logged protest 


\section{Unabridged Results for Protest, city-level Defunding, and State-level Police Reform}

\begin{tabular}{|c|c|c|c|c|c|c|c|}
\hline & \multicolumn{7}{|c|}{ Change in police budget as a share of city budget, 2019/20 - 2020/21 } \\
\hline & (1) & (2) & (3) & (4) & (5) & (6) & (7) \\
\hline Protesters per month per 100,000 population & 0.0001 & 0.0001 & 0.0001 & $0.0002^{+}$ & $0.0002^{+}$ & $0.0002^{*}$ & $0.0002^{+}$ \\
\hline Veteran population share & & -0.00001 & -0.00001 & -0.00001 & -0.00001 & -0.00001 & -0.00001 \\
\hline Foreign-born population share & & 0.00000 & 0.00000 & -0.00000 & -0.00000 & -0.00000 & -0.00000 \\
\hline Average household size & & 0.312 & 0.452 & 0.143 & 0.213 & 0.285 & 0.341 \\
\hline Median age & & 0.011 & -0.0003 & -0.004 & -0.001 & 0.016 & 0.017 \\
\hline Asian population share & & & 1.075 & 2.261 & 1.860 & 2.948 & 2.868 \\
\hline Black population share & & & -0.699 & 0.081 & -0.235 & -0.316 & -0.575 \\
\hline Hispanic population share & & & -0.779 & 0.050 & -0.209 & 0.267 & 0.078 \\
\hline White population share & & & -1.059 & -1.270 & -1.450 & -1.663 & -1.839 \\
\hline Covid-19 deaths & & & & 0.0001 & 0.0002 & 0.0001 & 0.0001 \\
\hline 2020 Presidential Election Dem vote share & & & & -1.591 & -1.561 & -1.296 & -1.255 \\
\hline Poverty rate & & & & -0.020 & -0.015 & -0.011 & -0.009 \\
\hline Arrests per month per 100,000 population & & & & & 0.002 & 0.002 & 0.003 \\
\hline Participant injuries per month per 100,000 population & & & & & $-0.664^{*}$ & $-0.695^{*}$ & $-0.671^{*}$ \\
\hline Police injuries per month per 100,000 population & & & & & 0.098 & $0.118^{+}$ & $0.114^{+}$ \\
\hline Property damage per month per 100,000 population & & & & & 0.026 & 0.039 & 0.041 \\
\hline State capital dummy & & & & & & -0.498 & -0.514 \\
\hline Distance from Minneapolis, MN & & & & & & -0.001 & -0.0005 \\
\hline Time from May 25 th to budget approval & & & & & & & 0.154 \\
\hline Squared time from May 25th to budget approval & & & & & & & -0.021 \\
\hline Constant & -0.047 & -1.150 & -0.197 & 1.636 & 1.554 & 1.202 & 0.996 \\
\hline$N$ & 217 & 217 & 217 & 211 & 211 & 211 & 211 \\
\hline $\mathrm{R}^{2}$ & 0.012 & 0.025 & 0.038 & 0.049 & 0.062 & 0.076 & 0.078 \\
\hline Adjusted $\mathrm{R}^{2}$ & 0.008 & 0.002 & -0.003 & -0.009 & -0.016 & -0.010 & -0.019 \\
\hline
\end{tabular}

Table I.1: Unabridged results for city-level number of protesters and defunding, with and without controls

\begin{tabular}{|c|c|c|c|c|c|c|c|}
\hline & \multicolumn{7}{|c|}{ Change in police budget as a share of city budget, 2019/20 - 2020/21 } \\
\hline & (1) & (2) & (3) & (4) & $(5)$ & $(6)$ & (7) \\
\hline Protesters per month per 100,000 population & $0.0002^{+}$ & $0.0003^{*}$ & $0.0003^{+}$ & $0.0003^{*}$ & $0.0003^{*}$ & $0.0003^{*}$ & $0.0003^{*}$ \\
\hline Black population share & 0.413 & 0.860 & -0.056 & 0.713 & 0.456 & 0.442 & 0.236 \\
\hline Veteran population share & & -0.00001 & -0.00001 & -0.00001 & -0.00001 & -0.00001 & -0.00001 \\
\hline Foreign-born population share & & 0.00000 & 0.00000 & -0.00000 & -0.00000 & -0.00000 & -0.00000 \\
\hline Average household size & & 0.357 & 0.363 & 0.071 & 0.133 & 0.214 & 0.231 \\
\hline Median age & & 0.008 & -0.004 & -0.007 & -0.003 & 0.017 & 0.018 \\
\hline Asian population share & & & 1.134 & 2.340 & 2.041 & 3.278 & 3.227 \\
\hline Hispanic population share & & & -0.535 & 0.264 & 0.055 & 0.613 & 0.516 \\
\hline White population share & & & -1.241 & -1.513 & -1.752 & -2.002 & -2.128 \\
\hline Covid-19 deaths & & & & 0.0002 & 0.0002 & 0.0002 & 0.0002 \\
\hline 2020 Presidential Election Dem vote share & & & & -1.585 & -1.624 & -1.353 & -1.301 \\
\hline Poverty rate & & & & -0.017 & -0.012 & -0.008 & -0.007 \\
\hline Arrests per month per 100,000 population & & & & & 0.005 & 0.005 & 0.005 \\
\hline Participant injuries per month per 100,000 population & & & & & $-0.665^{* *}$ & $-0.695^{*}$ & $-0.688^{*}$ \\
\hline Police injuries per month per 100,000 population & & & & & $0.118^{*}$ & $0.140^{*}$ & $0.139^{*}$ \\
\hline Property damage per month per 100,000 population & & & & & -0.019 & -0.009 & -0.009 \\
\hline State capital dummy & & & & & & -0.491 & -0.503 \\
\hline Distance from Minneapolis, MN & & & & & & $-0.001^{+}$ & $-0.001^{+}$ \\
\hline Time from May 25th to budget approval & & & & & & & 0.107 \\
\hline Squared time from May 25th to budget approval & & & & & & & -0.017 \\
\hline Protesters $\times$ Black population share & $-0.001^{+}$ & $-0.001^{+}$ & $-0.001^{+}$ & $-0.001^{+}$ & $-0.001^{*}$ & $-0.001^{*}$ & $-0.001^{*}$ \\
\hline Constant & -0.106 & -1.318 & 0.114 & 1.895 & 1.865 & 1.433 & 1.369 \\
\hline$N$ & 217 & 217 & 217 & 211 & 211 & 211 & 211 \\
\hline $\mathrm{R}^{2}$ & 0.021 & 0.033 & 0.047 & 0.057 & 0.072 & 0.089 & 0.089 \\
\hline Adjusted $\mathrm{R}^{2}$ & 0.007 & 0.001 & 0.001 & -0.005 & -0.010 & -0.002 & -0.012 \\
\hline
\end{tabular}

Table I.2: Unabridged results for city-level number of protesters and defunding, with an interaction term for Black population share 


\begin{tabular}{|c|c|c|c|c|c|c|c|}
\hline & \multicolumn{7}{|c|}{ Change in police budget as a share of city budget, $2019 / 20-2020 / 21$} \\
\hline & (1) & (2) & (3) & (4) & (5) & (6) & (7) \\
\hline Protesters per month per 100,000 population & 0.00001 & 0.00004 & 0.00004 & 0.0001 & 0.0002 & 0.0002 & 0.0002 \\
\hline Poverty rate & -0.032 & -0.025 & -0.016 & -0.022 & -0.014 & -0.011 & -0.009 \\
\hline Veteran population share & & -0.00001 & -0.00001 & -0.00001 & -0.00001 & -0.00001 & -0.00001 \\
\hline Foreign-born population share & & 0.00000 & 0.00000 & -0.00000 & -0.00000 & -0.00000 & -0.00000 \\
\hline Average household size & & 0.219 & 0.379 & 0.154 & 0.211 & 0.284 & 0.339 \\
\hline Median age & & -0.005 & -0.008 & -0.004 & -0.001 & 0.016 & 0.017 \\
\hline Asian population share & & & 1.165 & 2.306 & 1.853 & 2.944 & 2.859 \\
\hline Black population share & & & -0.432 & 0.105 & -0.240 & -0.319 & -0.584 \\
\hline Hispanic population share & & & -0.646 & 0.030 & -0.206 & 0.270 & 0.083 \\
\hline White population share & & & -0.920 & -1.202 & -1.461 & -1.672 & -1.856 \\
\hline Covid-19 deaths & & & & 0.0001 & 0.0002 & 0.0001 & 0.0001 \\
\hline 2020 Presidential Election Dem vote share & & & & -1.566 & -1.566 & -1.300 & -1.262 \\
\hline Arrests per month per 100,000 population & & & & & 0.002 & 0.002 & 0.003 \\
\hline Participant injuries per month per 100,000 population & & & & & $-0.665^{* *}$ & $-0.696^{*}$ & $-0.673^{*}$ \\
\hline Police injuries per month per 100,000 population & & & & & 0.098 & $0.118^{+}$ & $0.114^{+}$ \\
\hline Property damage per month per 100,000 population & & & & & 0.026 & 0.038 & 0.041 \\
\hline State capital dummy & & & & & & -0.497 & $-0.512^{+}$ \\
\hline Distance from Minneapolis, MN & & & & & & -0.001 & -0.001 \\
\hline Time from May 25 th to budget approval & & & & & & & 0.154 \\
\hline Squared time from May 25th to budget approval & & & & & & & -0.021 \\
\hline Protesters $\times$ poverty rate & 0.00001 & 0.00001 & 0.00001 & 0.00000 & -0.00000 & -0.00000 & -0.00000 \\
\hline Constant & 0.394 & 0.017 & 0.304 & 1.568 & 1.565 & 1.209 & 1.009 \\
\hline$N$ & 217 & 217 & 217 & 211 & 211 & 211 & 211 \\
\hline $\mathrm{R}^{2}$ & 0.018 & 0.028 & 0.040 & 0.049 & 0.062 & 0.076 & 0.078 \\
\hline Adjusted $\mathrm{R}^{2}$ & 0.005 & -0.004 & -0.012 & -0.014 & -0.021 & -0.015 & -0.025 \\
\hline
\end{tabular}

Table I.3: Unabridged results for city-level number of protesters and defunding, with an interaction term for poverty rate

\begin{tabular}{|c|c|c|c|c|c|c|c|}
\hline & \multicolumn{7}{|c|}{ Change in police budget as a share of city budget, $2019 / 20-2020 / 21$} \\
\hline & (1) & (2) & (3) & (4) & (5) & (6) & (7) \\
\hline Protesters per month per 100,000 population & $0.001^{*}$ & $0.001^{*}$ & $0.001^{* *}$ & $0.001^{* *}$ & $0.001^{*}$ & $0.001^{* *}$ & $0.001^{* *}$ \\
\hline 2020 Presidential Election Democratic vote share & 0.338 & 0.260 & -0.862 & -0.730 & -0.767 & -0.413 & -0.314 \\
\hline Veteran population share & & -0.00001 & -0.00001 & -0.00001 & -0.00001 & -0.00001 & -0.00001 \\
\hline Foreign-born population share & & 0.00000 & 0.00000 & -0.00000 & -0.00000 & -0.00000 & -0.00000 \\
\hline Average household size & & 0.312 & 0.325 & 0.060 & 0.131 & 0.167 & 0.274 \\
\hline Median age & & 0.012 & 0.005 & -0.012 & -0.008 & 0.005 & 0.003 \\
\hline Asian population share & & & 2.420 & 2.743 & 2.347 & 3.362 & 3.268 \\
\hline Black population share & & & 0.159 & 0.574 & 0.238 & 0.180 & -0.132 \\
\hline Hispanic population share & & & -0.250 & 0.304 & 0.048 & 0.500 & 0.185 \\
\hline White population share & & & -0.908 & -0.987 & -1.178 & -1.401 & -1.628 \\
\hline Covid-19 deaths & & & & 0.0002 & 0.0002 & 0.0002 & 0.0002 \\
\hline Poverty rate & & & & -0.029 & -0.024 & -0.023 & -0.020 \\
\hline Arrests per month per 100,000 population & & & & & 0.002 & 0.002 & 0.003 \\
\hline Participant injuries per month per 100,000 population & & & & & $-0.616^{*}$ & $-0.655^{*}$ & $-0.602^{+}$ \\
\hline Police injuries per month per 100,000 population & & & & & 0.098 & 0.122 & 0.114 \\
\hline Property damage per month per 100,000 population & & & & & 0.019 & 0.028 & 0.034 \\
\hline State capital dummy & & & & & & $-0.630^{*}$ & $-0.664^{*}$ \\
\hline Distance from Minneapolis, MN & & & & & & -0.0005 & -0.0004 \\
\hline Time from May 25th to budget approval & & & & & & & 0.226 \\
\hline Squared time from May 25th to budget approval & & & & & & & -0.027 \\
\hline Protesters $\times$ Dem vote share & $-0.001^{*}$ & $-0.001^{*}$ & $-0.001^{*}$ & $-0.001^{* *}$ & $-0.001^{*}$ & $-0.001^{* *}$ & $-0.001^{* *}$ \\
\hline Constant & -0.276 & -1.377 & -0.114 & 1.359 & 1.281 & 1.133 & 0.699 \\
\hline$N$ & 216 & 216 & 216 & 211 & 211 & 211 & 211 \\
\hline $\mathrm{R}^{2}$ & 0.027 & 0.039 & 0.058 & 0.063 & 0.074 & 0.090 & 0.093 \\
\hline Adjusted $\mathrm{R}^{2}$ & 0.013 & 0.006 & 0.007 & 0.001 & -0.007 & -0.00001 & -0.007 \\
\hline
\end{tabular}

Table I.4: Unabridged results for city-level number of protesters and defunding, with an interaction term for Dem vote share 


\begin{tabular}{|c|c|c|c|c|c|c|c|}
\hline & \multicolumn{7}{|c|}{ State-level number of approved police reform bills, 2020/21 } \\
\hline & (1) & (2) & (3) & (4) & (5) & (6) & (7) \\
\hline Protesters per month per 100,000 urban population & 0.0001 & $0.0003^{* *}$ & $0.0003^{* * *}$ & $0.0003^{*}$ & $0.0002^{*}$ & $0.0002^{*}$ & $0.0002^{*}$ \\
\hline High school graduate population share & & $-0.143^{+}$ & -0.099 & -0.106 & -0.080 & $-0.245^{*}$ & -0.061 \\
\hline College graduate population share & & $0.063^{*}$ & 0.038 & 0.017 & 0.028 & 0.041 & 0.051 \\
\hline Veteran population share & & $0.269^{*}$ & $0.300^{* *}$ & $0.289^{*}$ & $0.282^{*}$ & 0.182 & $0.223^{+}$ \\
\hline Foreign-born population share & & 0.034 & $0.082^{*}$ & $0.075^{+}$ & $0.081^{+}$ & $0.128^{* *}$ & $0.080^{+}$ \\
\hline Median age & & -0.137 & $-0.194^{*}$ & $-0.200^{*}$ & $-0.200^{*}$ & $-0.192^{* *}$ & $-0.187^{*}$ \\
\hline White population share & & & 0.059 & 0.062 & 0.055 & 0.067 & 0.035 \\
\hline Black population share & & & $0.065^{+}$ & $0.068^{+}$ & $0.064^{+}$ & $0.067^{+}$ & 0.056 \\
\hline Asian population share & & & 0.034 & 0.031 & 0.031 & 0.028 & 0.012 \\
\hline Covid-19 deaths per million population & & & & -0.0001 & 0.0001 & -0.0003 & 0.0002 \\
\hline Poverty rate & & & & -0.025 & -0.012 & -0.002 & 0.021 \\
\hline 2020 Presidential Election Democratic vote share & & & & 1.386 & 0.338 & -0.844 & -0.228 \\
\hline Participant injuries per month per 100,000 urban population & & & & & -0.127 & -0.516 & -0.161 \\
\hline Police injuries per month per 100,000 urban population & & & & & -0.285 & $-0.603^{+}$ & -0.329 \\
\hline Property damage per month per 100,000 urban population & & & & & $0.785^{* * *}$ & $0.809^{* * *}$ & $0.841^{* * *}$ \\
\hline Violent crimes per 100,000 population, in 2019 & & & & & & $-0.00002^{*}$ & \\
\hline Police officers per 100,000 population, in 2019 & & & & & & & -0.003 \\
\hline Constant & $1.047^{* * *}$ & $14.427^{*}$ & 7.150 & 8.302 & 6.272 & $21.370^{+}$ & 6.324 \\
\hline$N$ & 51 & 51 & 51 & 51 & 51 & 51 & 51 \\
\hline Log Likelihood & -152.960 & -127.143 & -123.485 & -123.083 & -118.806 & -113.154 & -116.788 \\
\hline AIC & 309.920 & 268.285 & 266.969 & 272.166 & 269.611 & 260.309 & 267.576 \\
\hline
\end{tabular}

Table I.5: Unabridged results for state-level number of protesters and approvedreform bills, with and without controls

\begin{tabular}{|c|c|c|c|c|c|c|c|}
\hline & \multicolumn{7}{|c|}{ State-level number of proposed police reform bills, $2020 / 21$} \\
\hline & (1) & (2) & (3) & (4) & (5) & (6) & (7) \\
\hline Protesters per month per 100,000 urban population & 0.00005 & 0.0001 & 0.0001 & 0.0002 & 0.0001 & 0.0002 & 0.0001 \\
\hline High school graduate population share & & -0.006 & 0.026 & -0.021 & -0.009 & 0.083 & 0.010 \\
\hline College graduate population share & & -0.002 & -0.028 & 0.004 & 0.015 & 0.028 & 0.037 \\
\hline Veteran population share & & -0.162 & -0.115 & -0.113 & -0.145 & -0.097 & -0.187 \\
\hline Foreign-born population share & & $0.054^{* *}$ & $0.115^{* * *}$ & $0.103^{* *}$ & $0.098^{* *}$ & $0.071^{+}$ & $0.105^{* *}$ \\
\hline Median age & & 0.014 & -0.064 & -0.046 & -0.043 & -0.036 & -0.022 \\
\hline White population share & & & $0.085^{+}$ & 0.070 & $0.076^{+}$ & 0.071 & 0.055 \\
\hline Black population share & & & $0.094^{*}$ & $0.089^{*}$ & $0.092^{*}$ & $0.098^{*}$ & $0.084^{*}$ \\
\hline Asian population share & & & 0.059 & 0.057 & $0.070^{+}$ & $0.081^{+}$ & 0.052 \\
\hline Covid-19 deaths per million population & & & & 0.00003 & 0.0002 & $0.0005^{+}$ & 0.0003 \\
\hline Poverty rate & & & & -0.042 & -0.004 & -0.013 & 0.011 \\
\hline 2020 Presidential Election Democratic vote share & & & & -2.426 & -3.299 & $-4.126^{+}$ & $-4.589^{*}$ \\
\hline Participant injuries per month per 100,000 urban population & & & & & -1.175 & -1.147 & -1.146 \\
\hline Police injuries per month per 100,000 urban population & & & & & -0.439 & -0.314 & $-0.494^{+}$ \\
\hline Property damage per month per 100,000 urban population & & & & & $1.342^{* *}$ & $1.441^{* * *}$ & $1.439^{* * *}$ \\
\hline Violent crimes per 100,000 population, in 2019 & & & & & & 0.00001 & \\
\hline Police officers per 100,000 population, in 2019 & & & & & & & $-0.002^{+}$ \\
\hline Constant & $3.175^{* * *}$ & 3.758 & -4.448 & 0.832 & -1.244 & -10.442 & -1.179 \\
\hline$N$ & 51 & 51 & 51 & 51 & 51 & 51 & 51 \\
\hline Log Likelihood & -684.168 & -476.557 & -435.781 & -428.281 & -364.778 & -349.595 & -353.396 \\
\hline AIC & $1,372.337$ & 967.114 & 891.561 & 882.562 & 761.557 & 733.190 & 740.792 \\
\hline
\end{tabular}

Table I.6: Unabridged results for state-level number of protesters and proposedreform bills, with and without controls 


\begin{tabular}{|c|c|c|c|c|c|c|c|}
\hline & \multicolumn{7}{|c|}{ State-level number of proposed police reform bills, $2020 / 21$} \\
\hline & (1) & (2) & (3) & (4) & (5) & (6) & (7) \\
\hline Protesters per month per 100,000 urban population & -0.0002 & -0.0001 & -0.0001 & -0.0001 & -0.0003 & -0.0003 & -0.0004 \\
\hline Black population share & -0.020 & -0.003 & $0.083^{*}$ & 0.072 & 0.064 & 0.068 & 0.064 \\
\hline High school graduate population share & & 0.028 & 0.006 & -0.047 & -0.037 & 0.030 & -0.039 \\
\hline College graduate population share & & -0.005 & -0.008 & 0.009 & 0.018 & 0.029 & 0.017 \\
\hline Veteran population share & & -0.073 & -0.024 & -0.100 & -0.114 & -0.080 & -0.111 \\
\hline Foreign-born population share & & $0.061^{\cdots \cdots}$ & $0.107^{* * *}$ & $0.096^{* \cdots}$ & $0.087^{\cdots}$ & $0.067^{*}$ & $0.087^{* * *}$ \\
\hline Median age & & -0.021 & $-0.089^{+}$ & -0.035 & -0.043 & -0.037 & -0.044 \\
\hline White population share & & & $0.099^{*}$ & $0.075^{+}$ & $0.084^{*}$ & $0.079^{+}$ & $0.086^{+}$ \\
\hline Asian population share & & & $0.072^{*}$ & 0.054 & $0.066^{+}$ & 0.072 & 0.067 \\
\hline Covid-19 deaths per million population & & & & -0.0003 & -0.0001 & 0.0001 & -0.0001 \\
\hline Poverty rate & & & & -0.062 & -0.029 & -0.034 & -0.030 \\
\hline 2020 Presidential Election Democratic vote share & & & & -2.224 & -2.722 & -3.415 & -2.622 \\
\hline Participant injuries per month per 100,000 urban population & & & & & $-1.388^{*}$ & $-1.364^{*}$ & $-1.391^{*}$ \\
\hline Police injuries per month per 100,000 urban population & & & & & $-0.661^{*}$ & $-0.559^{*}$ & $-0.660^{*}$ \\
\hline Property damage per month per 100,000 urban population & & & & & $1.731^{* *}$ & $1.781^{* * *}$ & $1.726^{* * *}$ \\
\hline Violent crimes per 100,000 population, in 2019 & & & & & & 0.00001 & \\
\hline Police officers per 100,000 population, in 2019 & & & & & & & 0.0002 \\
\hline Protesters $\times$ Black population share & $0.0001^{* *}$ & $0.00004^{*}$ & $0.00004^{* *}$ & $0.00005^{* *}$ & $0.0001^{\cdots * *}$ & $0.0001^{* *}$ & $0.0001^{\cdots}$ \\
\hline Constant & $2.943^{* * *}$ & 1.231 & -4.244 & 2.858 & 1.079 & -5.475 & 1.090 \\
\hline$N$ & 51 & 51 & 51 & 51 & 51 & 51 & 51 \\
\hline Log Likelihood & -544.826 & -433.120 & -398.443 & -386.622 & -297.026 & -289.151 & -296.984 \\
\hline AIC & $1,097.652$ & 884.240 & 818.887 & 801.244 & 628.051 & 614.302 & 629.968 \\
\hline
\end{tabular}

Table I.7: Unabridged results for state-level number of protesters and proposed reform bills, with an interaction term for Black population share

\begin{tabular}{|c|c|c|c|c|c|c|c|}
\hline & \multicolumn{7}{|c|}{ State-level number of proposed police reform bills, $2020 / 21$} \\
\hline & (1) & (2) & (3) & (4) & (5) & (6) & (7) \\
\hline Protesters per month per 100,000 urban population & -0.002 & -0.001 & -0.001 & -0.001 & $-0.001^{*}$ & $-0.001^{*}$ & $-0.001^{*}$ \\
\hline Poverty rate & $-0.200^{*}$ & $-0.147^{+}$ & $-0.157^{+}$ & $-0.159^{+}$ & $-0.149^{+}$ & $-0.147^{+}$ & -0.131 \\
\hline High school graduate population share & & -0.075 & -0.036 & -0.054 & -0.053 & 0.026 & -0.036 \\
\hline College graduate population share & & 0.013 & -0.019 & 0.005 & 0.021 & 0.031 & 0.040 \\
\hline Veteran population share & & -0.127 & -0.079 & -0.093 & -0.133 & -0.097 & -0.170 \\
\hline Foreign-born population share & & 0.029 & $0.095^{* *}$ & $0.092^{* *}$ & $0.082^{* *}$ & $0.062^{+}$ & $0.087^{* *}$ \\
\hline Median age & & 0.013 & -0.071 & -0.047 & -0.046 & -0.039 & -0.027 \\
\hline White population share & & & $0.095^{*}$ & $0.082^{+}$ & $0.092^{*}$ & $0.088^{+}$ & 0.073 \\
\hline Black population share & & & $0.107^{*}$ & $0.101^{*}$ & $0.106^{*}$ & $0.111^{*}$ & $0.098^{*}$ \\
\hline Asian population share & & & $0.070^{+}$ & 0.066 & $0.083^{+}$ & $0.091^{+}$ & 0.067 \\
\hline Covid-19 deaths per million population & & & & -0.00004 & 0.0001 & $0.0003^{+}$ & 0.0002 \\
\hline 2020 Presidential Election Democratic vote share & & & & -1.924 & -3.054 & -3.799 & $-4.191^{+}$ \\
\hline Participant injuries per month per 100,000 urban population & & & & & $-1.327^{+}$ & $-1.287^{+}$ & $-1.308^{+}$ \\
\hline Police injuries per month per 100,000 urban population & & & & & $-0.433^{+}$ & -0.334 & $-0.475^{+}$ \\
\hline Property damage per month per 100,000 urban population & & & & & $1.560^{* * *}$ & $1.621^{* * *}$ & $1.657^{* * *}$ \\
\hline Violent crimes per 100,000 population, in 2019 & & & & & & 0.00001 & \\
\hline Police officers per 100,000 population, in 2019 & & & & & & & -0.002 \\
\hline Protesters $\times$ poverty rate & 0.0002 & 0.0001 & 0.0001 & $0.0001^{+}$ & $0.0001^{*}$ & $0.0001^{*}$ & $0.0001^{*}$ \\
\hline Constant & $5.099^{* * *}$ & 10.999 & 1.569 & 3.693 & 2.626 & -5.316 & 2.637 \\
\hline$N$ & 51 & 51 & 51 & 51 & 51 & 51 & 51 \\
\hline Log Likelihood & -616.578 & -458.335 & -414.389 & -411.425 & -336.503 & -326.658 & -328.014 \\
\hline AIC & $1,241.157$ & 934.669 & 852.778 & 850.849 & 707.006 & 689.317 & 692.029 \\
\hline
\end{tabular}

${ }^{+} \mathrm{p}<0.1 ;{ }^{*} \mathrm{p}<0.05 ;{ }^{*} \mathrm{p}<0.01 ; \cdots+\mathrm{p}<0.001$

Table I.8: Unabridged results for state-level number of protesters and proposedreform bills, with an interaction term for poverty rate 
State-level number of proposed police reform bills, 2020/21

\begin{tabular}{|c|c|c|c|c|c|c|c|}
\hline & (1) & (2) & (3) & (4) & (5) & (6) & (7) \\
\hline 2020 Presidential Election Democratic vote share & 2.107 & -2.008 & -1.108 & -1.233 & -2.589 & -3.922 & $-3.799^{+}$ \\
\hline High school graduate population share & & -0.064 & -0.018 & -0.046 & -0.022 & 0.077 & -0.005 \\
\hline College graduate population share & & 0.046 & 0.005 & 0.003 & 0.013 & 0.027 & 0.036 \\
\hline Foreign-born population share & & $0.061^{* * *}$ & $0.120^{* * *}$ & $0.110^{* *}$ & $0.100^{* *}$ & $0.072^{+}$ & $0.107^{* *}$ \\
\hline Median age & & 0.036 & -0.043 & -0.041 & -0.043 & -0.036 & -0.021 \\
\hline White population share & & & $0.086^{+}$ & $0.082^{+}$ & $0.081^{+}$ & 0.072 & 0.060 \\
\hline Black population share & & & $0.103^{*}$ & $0.104^{*}$ & $0.097^{*}$ & $0.099^{*}$ & $0.089^{*}$ \\
\hline Poverty rate & & & & -0.047 & -0.009 & -0.014 & 0.006 \\
\hline Participant injuries per month per 100,000 urban population & & & & & -1.135 & -1.135 & -1.111 \\
\hline Police injuries per month per 100,000 urban population & & & & & $-0.462^{+}$ & -0.323 & $-0.517^{+}$ \\
\hline Property damage per month per 100,000 urban population & & & & & $1.237^{*}$ & $1.411^{* *}$ & $1.337^{* *}$ \\
\hline Violent crimes per 100,000 population, in 2019 & & & & & & 0.00001 & \\
\hline Police officers per 100,000 population, in 2019 & & & & & & & $-0.003^{+}$ \\
\hline Protesters $\times$ Dem vote share & 0.0003 & -0.001 & $-0.002^{*}$ & $-0.002^{*}$ & -0.001 & -0.0003 & -0.001 \\
\hline
\end{tabular}

${ }^{+} \mathrm{p}<0.1 ;{ }^{*} \mathrm{p}<0.05 ;{ }^{* *} \mathrm{p}<0.01 ;{ }^{* * *} \mathrm{p}<0.001$

Table I.9: Unabridged results for state-level number of protesters and proposedreform bills, with an interaction term for Dem vote share

\section{J. BLM-related Google Search Terms}

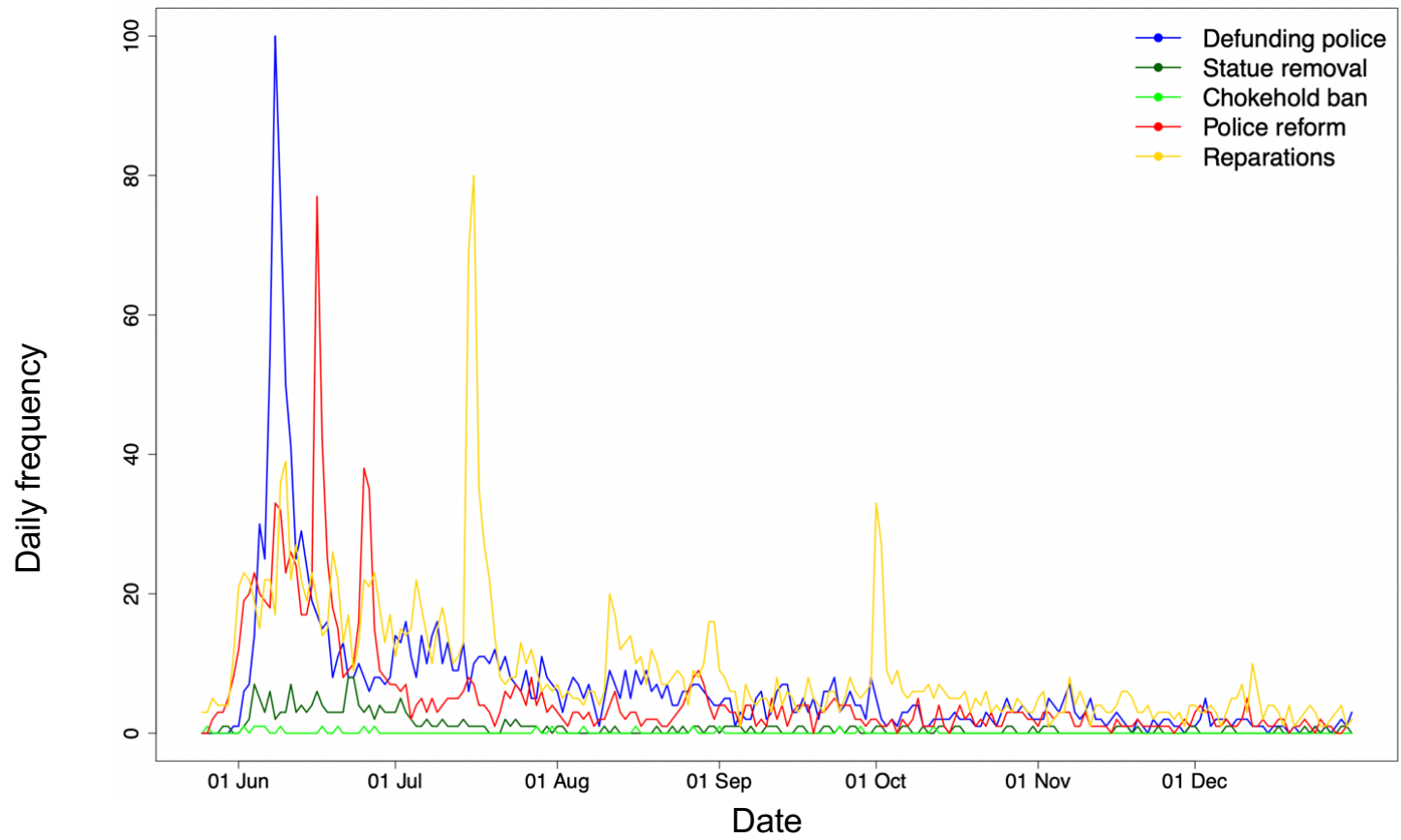

Figure K.1: Daily frequency of BLM-related search terms, 25th May - $31^{\text {st }}$ Dec 2020 


\section{K. Minneapolis Total Daily Protestors}

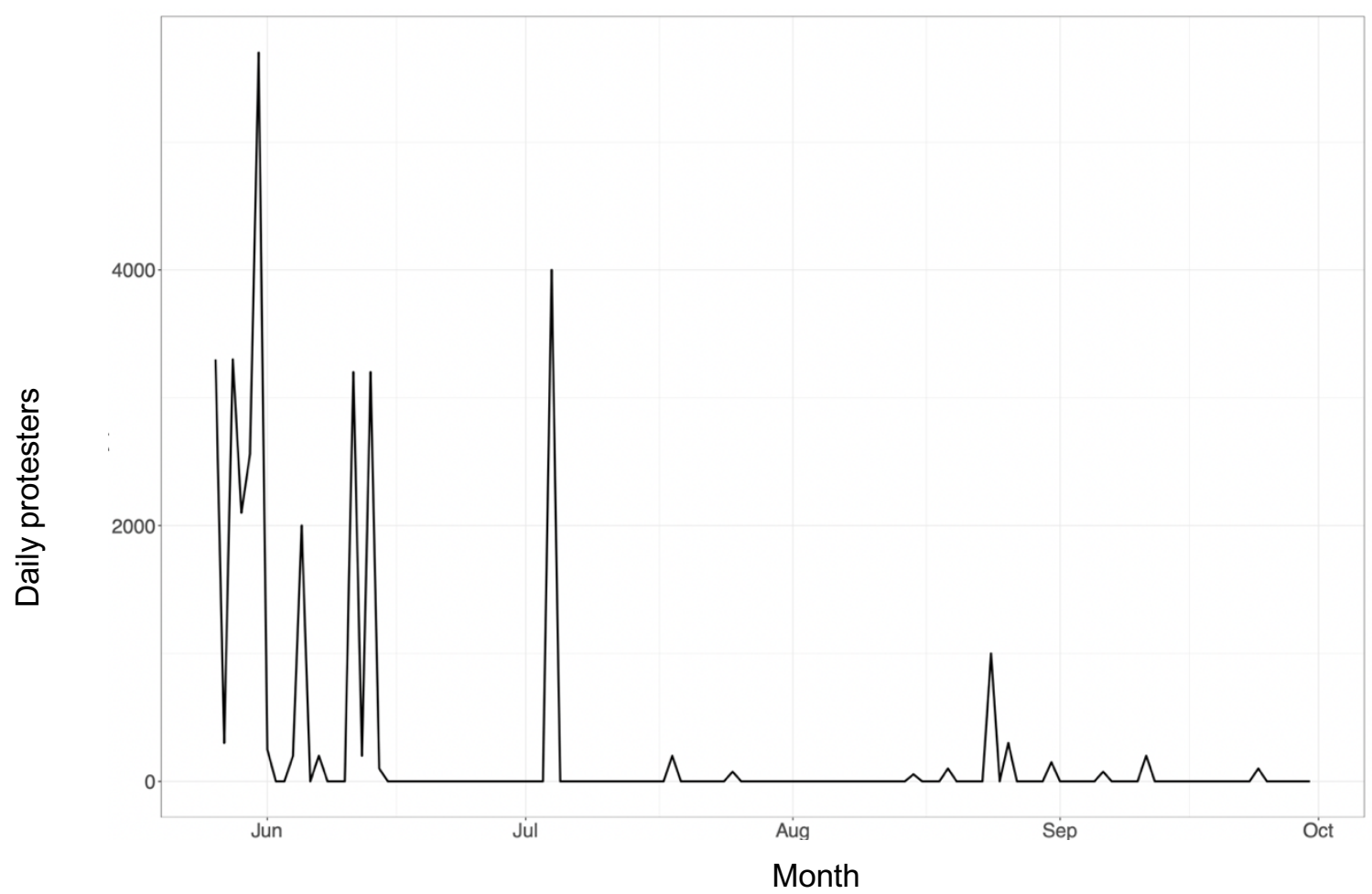

Figure L.1: Daily total protesters in Minneapolis, MN from May - Oct 2020

\section{M modelling with Weather Instruments}

In Table M.1 we find that rainfall is a relevant instrument for the number of protesters. In Table M.2, we show however that rainfall is also significantly related to Covid-19 cases and deaths.

Number of protesters

\begin{tabular}{lccc} 
& $(1)$ & $(2)$ & $(3)$ \\
\hline Deviation from average precipitation $(\mathrm{mm})$ & $-0.003^{*}$ & $-0.004^{* *}$ & $-0.004^{* *}$ \\
Constant & -0.073 & $3.554^{*}$ & 0.914 \\
Population controls & $\mathrm{Y}$ & $\mathrm{Y}$ & $\mathrm{Y}$ \\
Demographic controls & $\mathrm{N}$ & $\mathrm{Y}$ & $\mathrm{Y}$ \\
Economic controls & $\mathrm{N}$ & $\mathrm{N}$ & $\mathrm{Y}$ \\
$N$ & 3,140 & 3,140 & 3,128 \\
$\mathrm{R}^{2}$ & 0.345 & 0.349 & 0.354 \\
Adjusted $\mathrm{R}^{2}$ & 0.345 & 0.348 & 0.352 \\
\hline
\end{tabular}

${ }^{+} \mathrm{p}<0.1 ;{ }^{*} \mathrm{p}<0.05 ;{ }^{* * *} \mathrm{p}<0.01 ;{ }^{* * *} \mathrm{p}<0.001$ 
Table M.1: Testing the relevance of rainfall as an instrument

\begin{tabular}{|c|c|c|c|c|c|c|}
\hline & \multicolumn{3}{|c|}{ Total Covid- 19 cases } & \multicolumn{3}{|c|}{ Total Covid-19 deaths } \\
\hline & (1) & (2) & (3) & (4) & $(5)$ & (6) \\
\hline Deviation from average precipitation (mm) & $-64.606^{* *}$ & $-74.199^{* * *}$ & $-73.498^{* *}$ & $-3.792^{* *}$ & $-4.673^{* * *}$ & $-4.573^{* *}$ \\
\hline Constant & $-2,012.997$ & $-8,010.616$ & $-40,499.600^{* *}$ & -46.619 & 512.123 & $-2,574.818^{* *}$ \\
\hline Population controls & $\mathrm{Y}$ & $\mathrm{Y}$ & $\mathrm{Y}$ & $\mathrm{Y}$ & $\mathrm{Y}$ & $\mathrm{Y}$ \\
\hline Demographic controls & $\mathrm{N}$ & $\mathrm{Y}$ & $\mathrm{Y}$ & $\mathrm{N}$ & $\mathrm{Y}$ & $\mathrm{Y}$ \\
\hline Economic controls & $\mathrm{N}$ & $\mathrm{N}$ & $\mathrm{Y}$ & $\mathrm{N}$ & $\mathrm{N}$ & $\mathrm{Y}$ \\
\hline$N$ & 3,012 & 3,012 & 3,003 & 3,012 & 3,012 & 3,003 \\
\hline $\mathrm{R}^{2}$ & 0.605 & 0.608 & 0.610 & 0.428 & 0.431 & 0.439 \\
\hline Adjusted $\mathrm{R}^{2}$ & 0.605 & 0.607 & 0.609 & 0.427 & 0.430 & 0.437 \\
\hline
\end{tabular}

${ }^{+} \mathrm{p}<0.1 ;{ }^{*} \mathrm{p}<0.05 ;{ }^{* *} \mathrm{p}<0.01 ;{ }^{* * *} \mathrm{p}<0.001$

Table M.2: Testing the exclusion restriction for rainfall and Covid-19 